\author{
FILIPE FISCHMANN
}

\title{
Direito e Economia: um estudo propedêutico de suas fronteiras
}

Dissertação de Mestrado

ORIENTADOR: Professor Titular Dr. Tercio Sampaio Ferraz Jr.

FACULDADE DE DIREITO

UNIVERSIDADE DE SÃO PAULO

SÃO PAULO

2010 


\section{FILIPE FISCHMANN}

\section{Direito e Economia: um estudo propedêutico de suas fronteiras}

Dissertação de Mestrado apresentada à Faculdade de Direito da Universidade de São Paulo como requisito parcial para obtenção do título de Mestre.

ORIENTADOR: Professor Titular Dr. Tercio Sampaio Ferraz Jr.

FACULDADE DE DIREITO UNIVERSIDADE DE SÃO PAULO

SÃO PAULO

2010 


\section{RESUMO}

A presente dissertação de mestrado apresenta resultados de investigação sobre o relacionamento entre o direito e a economia não só na vertente da análise econômica do direito proposta pela Escola de Chicago, mas também pela corrente teórica do final do século XIX e início do século XX. Para tanto, considerou a relação entre direito e economia especialmente a partir de uma perspectiva da teoria retórica do direito, em que um modelo hermêneutico é desenvolvido a partir da teoria das funções da linguagem de Roman Jakobson. Utilizando este modelo interpretativo, é apresentada uma discussão sobre os limites para uma interpretação pautada pela análise econômica do direito, considerando-se uma análise normativa que buscasse se orientar pelos critérios de KaldorHicks e de Pareto. Quando voltada a exemplos, a presente dissertação destaca o direito concorrencial, tendo em vista o inter-relacionamento de conceitos econômicos e jurídicos neste ramo do direito, o que permite observar com maior clareza os desafios presentes na utilização de conceitos econômicos pelo discurso jurídico.

\section{PALAVRAS-CHAVE:}

Análise econômica do direito; teoria retórica do direito; funções da linguagem; teoria geral do direito; direito e economia. 


\begin{abstract}
The present master's thesis presents results of an investigation on Law \& Economics, not just based on the economic analysis of law developed by the Chicago School, but also based in the theoretical approach developed at the end of the nineteenth century and during the beginnings of the twentieth. For that purpose, this thesis especially considered the relation between Law and Economics from the perspective of rhetorical theory of law, in which is developed a hermeneutic model, departing from the Roman Jakobson's model of functions of language. Using that interpretative model, it is presented a discussion on the limits of the interpretation directed by the economic analysis of law, in consideration of a normative analysis which is oriented by the Kaldor-Hicks criterion or the Pareto criterion. The examples in the present master's thesis are in their majority taken from the competition law that is the field in which the interrelationship between law and economics is more intense. This intense relationship makes able the analysis of the challenges which are posed by the adoption of economic concepts by the legal discourse.
\end{abstract}

\title{
KEYWORDS:
}

Economic analysis of law, rhetorical theory of law; functions of language; jurisprudence; law \& economics. 
Às minhas Avós, Ady e Tina 


\section{AGRADECIMENTOS}

Para o desenvolvimento do processo de Mestrado em suas diferentes fases, pude contar com a importante contribuição de diversas pessoas.

Em primeiro lugar, gostaria de manifestar minha gratidão ao meu Orientador e Mentor, Professor Tercio Sampaio Ferraz Jr., pelo seu constante estímulo e por seus preciosos conselhos, plenos de sabedoria e de importância prática elevada. Sua forma de entender o direito tem influenciado o meu pensamento desde as aulas de Introdução ao Estudo do Direito, o que foi aprofundado por ocasião de sua orientação da minha Iniciação Científica e reforçado nesta orientação do Mestrado. Muitíssimo obrigado!

Também gostaria de agradecer aos Professores Samuel Rodrigues Barbosa e Juliano Souza de Albuquerque Maranhão, pelas sugestões e críticas oferecidas no Exame de Qualificação. Nas disciplinas cursadas durante a Pós-Graduação também pude contar com o auxílio de outros Professores. A todos sou grato pelos valorosos ensinamentos. Não obstante, gostaria de destacar os que pude desenvolver de maneira mais elaborada, por guardarem direta relação com esta Dissertação, os ensinamentos recebidos na Disciplina "Hermenêutica Jurídica e Teoria dos Significados" (DFD 5880), oferecida em conjunto por meu dileto Orientador, pelo Professor Celso Lafer e pela Professora Elza Antonia Pereira Cunha Boiteux e na Disciplina "Razão Jurídica e Razão Prática" (DFD5778), oferecida pelo Professor Ronaldo Porto Macedo Jr.. A estes professores, gostaria de deixar o meu particular agradecimento.

Nestes agradecimentos também gostaria de mencionar algumas pessoas que me ofereceram apoio no período de meu LL.M. em Munique. Aos Professores Wolfgang Fikentscher e Eva-Marina Bastian e em especial ao Professor Josef Drexl, também sou grato pela oportunidade oferecida.

Aos meus colegas nas disciplinas da Pós-Graduação também sou grato pela oportunidade de discutir os mais diversos temas.

À minha família, em especial meus pais, Adalberto e Roseli, meu irmão e minha cunhada Eduardo e Thais (e a futura geração representada pelo meu sobrinho, Gustavo), também sou grato por todo o apoio oferecido.

Finalmente, à minha namorada, Manuela, agradeço pela compreensão, motivação, inspiração e apoio constantes. 


\section{SUMÁRIO}

Resumo 1

$\begin{array}{ll}\text { Abstract } & 2\end{array}$

Agradecimentos 3

Sumário 4

1. Introdução 6

2. Conceituações $\quad 8$

2.1 Direito 8

$\begin{array}{ll}2.2 \text { Economia } & 13\end{array}$

3. Direito e economia: breve abordagem histórica 18

$\begin{array}{ll}3.1 \mathrm{O} \text { processo legislativo e a economia } & 18\end{array}$

3.1.1 O processo legislativo e a economia: a análise econômica do direito $\quad 18$ na virada do século $\mathrm{XX}$

3.1.2 O processo legislativo e a economia: a visão de Chicago 28

3.2 A aplicação do direito e a análise econômica 32

3.3 Análise econômica do direito no direito concorrencial 34

3.3.1 A Europa e uma abordagem mais econômica do direito concorrencial 37

4. Teoria retórica do direito e limites da aplicação jurídica 47

4.1 O direito como um fenômeno comunicativo 47

4.2 As funções da linguagem

4.3 A linguagem jurídica e o contexto $\quad 61$

4.4 As funções da linguagem aplicadas ao direito $\quad 65$ 
5.1 Limites de uma interpretação pautada pela análise econômica do direito 


\section{INTRODUÇÃO}

Com o fortalecimento de um enfoque tecnológico do direito, como o vivenciado na atualidade, o direito se torna mais sensível a uma visão econômica ${ }^{1}$. Ainda que este enfoque do direito como um saber tecnológico faça referência a um processo mais antigo, sua presença no debate jurídico no Brasil pode ser presenciada claramente nos últimos anos, em que há uma crescente influência da análise econômica do direito, sendo esta compreendida segundo os ditames do movimento "law \& economics" promovido pela Escola de Chicago.

Ao se fazer referência a este movimento, que tem suas origens na década de 60 e 70 do século passado, usualmente é olvidado que outras formas de análise econômica do direito já haviam sido praticadas anteriormente, com destaque para o movimento que se desenvolveu ao final do século XIX e início do século XX, na Europa continental, e que acabou por influenciar até mesmo o debate norte-americano. Sem esta menção ao debate anterior, os desenvolvimentos teóricos da Escola de Chicago surgem como uma abordagem completamente inédita e que poderiam iluminar por completo o atual debate jurídico. Colocando-se esta teoria em seu contexto histório, os objetivos buscados por ela podem ser melhor comprendidos e seus efetivos progressos também podem ser reconhecidos e acrescentados ao debate jurídico.

Neste sentido, o presente trabalho investiga como se dá o relacionamento entre o direito e a economia, não só segundo a visão defendida pela Escola de Chicago, mas também por outras vertentes de análise econômica do direito. Assim, há um destaque para os desenvolvimentos na teoria econômica que permitiram o desenvolvimento da análise econômica do direito desta vertente. Ademais, ao modelo interpretativo proposto por esta teoria é contraposto outro, especificamente fundamentado em uma análise retórica do direito.

Assim, para o desenvolvimento da presente análse, uma conceituação introdutória a respeito dos termos "direito" e "economia" é oferecida (Capítulo 2). A seguir (Capítulo 3) o desenvolvimento teórico da análise econômica do direito é exposto, apontando-se as particularidades do movimento de análise econômica do direito no final do século XIX e XX. Neste mesmo capítulo também se descrevem as principais características da análise proposta pela Escola de Chicago. Como principal ramo do direito em que esta teoria

\footnotetext{
${ }^{1}$ FERRAZ JR., Tercio Sampaio. Introdução ao estudo do direito: técnica, decisão, dominação. 3. ed. São Paulo: Atlas, 2001, p. 86.
} 
conseguiu se impor, destaca-se o direito concorrencial, que apresenta de maneira acentuada o relacionamento entre o direito e a economia. Mas mesmo neste campo do direito há significantes diferenças entre as abordagens dadas à matéria, como ficará claro pela exposição do recente debate na União Européia a respeito da "abordagem mais econômica" do direito concorrencial.

Como por meio desta abordagem procura-se alterar o conteúdo normativo de determinados dispositivos, uma referência aos limites da interpretação se faz necessária. Este delineamento da hermenêutica jurídica, com a exposição de um modelo interpretativo com raízes na teoria das funções da linguagem de Jakobson ${ }^{2}$, é exposto no Capítulo 4.

Estabelecida esta base teórica, adiante (Capítulo 5) é possível se analisar como a hermenêutica jurídica impõe limites a uma análise econômica do direito generalizada. Neste mesmo capítulo, o relacionamento do discurso jurídico e do discurso econômico é considerado, expondo-se as principais dificuldades e vantagens que esta abordagem interdisciplinar apresenta, tanto em relação aos dispositivos normativos que se valem de conceitos econômicos, quanto em relação à utilização de instrumentário econômico para a apuração de questões de fato.

Ao final, uma conclusão encerra o presente trabalho.

\footnotetext{
${ }^{2}$ Em seguimento à pesquisa por nós anteriormente desenvolvida. Vide FISCHMANN, Filipe. A função fática na Constituição Federal. Tese de Láurea apresentada à Faculdade de Direito da Universidade de São Paulo. São Paulo: 2006.
} 


\section{CONCEITUAÇÕES}

Os termos "direito" e "economia" podem se referir a uma diversidade de conteúdos. Com efeito, antes de começar a discutir o que é proposto pela análise econômica do direito, é conveniente que uma definição inicial para estes conceitos seja oferecida, ainda que em caráter preliminar e provisório, adequado ao escopo desta dissertação.

\subsection{O direito e o desenvolvimento de suas funções tradicionais}

Usualmente distingue-se a utilização da palavra "direito" conforme três significados básicos que lhe são atribuídos, isto é, "direito" em alusão ao ordenamento jurídico ("direito objetivo"), "direito" como uma possibilidade que o ordenamento concede a alguém ("direito subjetivo") e "direito" como um atributo moral", além de haver controvérsia a respeito da palavra "direito" como "ciência do direito"4. No presente trabalho, se não for especificado, o uso da palavra "direito" fará referência a direito objetivo, isto é ao ordenamento jurídico.

Não obstante, esta primeira abordagem não é satisfatória para os objetivos aqui traçados. Uma alternativa seria tentar refutar a possibilidade, bem como a utilidade, de se apresentar um conceito de direito, apontando que esta seria uma questão limitada à filosofia ${ }^{5}$. Outra alternativa é entender que a questão apresenta um mínimo de relevância e tentar oferecer uma forma de definição, que permita servir de parâmetro para o presente trabalho, ainda que não seja totalmente abrangente e represente um modelo final e definitivo.

Para o desenvolvimento de uma concepção de direito - ou de ordenamento jurídico - um elemento era historicamente destacado: a necessidade de haver um aspecto punitivo. Presente, de alguma forma, em diversos autores desde os primórdios do pensamento jurídico, esta era uma idéia que ainda se encontrava extremamente difundida

\footnotetext{
${ }^{3}$ FERRAZ JR., Tercio Sampaio. Introdução ao estudo do direito: técnica, decisão, dominação. 3. ed. São Paulo: Atlas, 2001, p. 34.

${ }^{4}$ TELLES JR., GOFFREDO. Iniciação na ciência do direito. São Paulo: Saraiva, 2001, p. 375.

5 "The acontextual question 'What is law' has only to do with philosophy (...)

Although I do not think that the question 'What is law' in the universalistic sense in which the question is posed in jurisprudence ever has to be asked or answered, this leaves unexplained why it is asked" (POSNER, Richard A. Law and legal theory in the UK and USA. Oxford: Oxford, 1996, p. 9 [grifo no original]).
} 
no século $\mathrm{XIX}^{6}$, estando também presente em autores influentes no século XX. Neste sentido, é famosa a importância que a sanção encontra na teoria kelseniana ${ }^{7}$ e mesmo Weber destaca como um critério extremamente relevante a verificação da existência de um aparato de força, que seja exercido por uma ou mais pessoas ${ }^{8}$.

Contudo, com os desenvolvimentos sociais que passam a ocorrer, o papel do Estado deixa de ser o de mero garantidor da segurança, passando a desenvolver outras funções ${ }^{9}$. Neste sentido, o direito mantém suas funções tradicionais, mas também passa a desenvolver outras funções ${ }^{10}$.

Deste modo, a sanção deixa de ser o elemento necessário para a definição do direito, que passa a se orientar por outros critérios. Com efeito, surgem teorias - como a de Niklas Luhmann, que será exposta a seguir -, as quais, em vez de caracterizar o direito por sua estrutura, passam a definir o direito como função.

Assim, para chegar à função do direito, Luhmann expõe que o ser humano vive em um mundo complexo e contingente, isto é, um mundo em que há mais possibilidades do que se pode perceber e que por isso pode gerar desapontamentos, pois o esperado pode

\footnotetext{
${ }^{6}$ FERRAZ JR., Tercio Sampaio. Introdução ao estudo do direito: técnica, decisão, dominação. 3. ed. São Paulo: Atlas, 2001, p. 83.

7 "Uma outra característica comum às ordens sociais a que chamamos Direito é que ela são ordens coativas, no sentido de que reagem contra as situações consideradas indesejáveis, por serem socialmente perniciosas particularmente contra condutas humanas indesejáveis - com um ato de coação, isto é, com um mal - como a privação da vida, da saúde, da liberdade, de bens econômicos e outros -, um mal que é aplicado ao destinatário mesmo contra a sua vontade, se necessário empregando até a força física - coativamente, portanto" (KELSEN, Hans. Teoria pura do direito. São Paulo: Martins Fontes, 2000, p. 35).

„Wir wollen vielmehr überall da von ,Rechtsordnung' sprechen, wo die Anwendung irgendwelcher, physischer oder psychischer Zwangsmittel in Aussicht steht, die von einem Zwangsapparat, d.h. von einer oder mehreren Personen ausgeübt wird, welche sich zu diesem Behuf für den Fall des Eintritts des betreffenden Tatbestandes bereithalten, wo also eine spezifische Art der Vergesellschaftung zum Zweck des ,Rechtszwanges' existiert. Der Besitz eines solchen Apparates für die Ausübung physischen Zwang war nicht immer ein Monopol der politischen Gemeinschaft" (WEBER, Max. Wirtschaft und Gesellschaft: Grundriss der verstehenden Soziologie. 5. ed. Tübingen: Mohr Siebeck, p. 185).

${ }^{9}$ FERRAZ JR., Tercio Sampaio. Introdução ao estudo do direito: técnica, decisão, dominação. 3. ed. São Paulo: Atlas, 2001, p. 84; GRAU, Eros. A ordem econômica na Constituição de 1988. 9. ed. São Paulo: Malheiros, 2004, p. 17; FERRAZ JR., Tercio Sampaio. As origens do Estado contemporâneo ou o Leviathan gestor da economia, in: FERRAZ JR., Tercio Sampaio. Direito Constitucional: liberdade de fumar, privacidade, Estado, direitos humanos e outros temas. Barueri: Manole, 2007, p. 428.

10 "O direito, como fenômeno marcadamente repressivo, modifica-se, tornando-se também e sobretudo um mecanismo de controle premunitivo: em vez de disciplinar e determinar sanções em em caso de indisciplina, dá maior ênfase a normas de organização, de condicionamentos que antecipam os comportamentos desejados, sem atribuir o caráter de punição às conseqüencias estabelecidas ao descumprimento. Nessa circunstância, o jurista, além de sistematizador e intérprete, passa a ser também um teórico do aconselhamento, das opções e das oportunidades, conforme um cálculo de custo-benefício, quando examina, por exemplo, incentivos fiscais, redução de impostos, vantagens contratuais, avalia a necessidade e a demora nos processo judiciais, etc" (FERRAZ JR., Tercio Sampaio. Introdução ao estudo do direito: técnica, decisão, dominação. 3. ed. São Paulo: Atlas, 2001, p. 84).
} 
não ocorrer ${ }^{11}$. Para lidar com estas condições de complexidade e contingência, há a necessidade de desenvolvimento de determinados mecanismos, como as expectativas cognitivas e as expectativas normativas. Em caso de desapontamento, as primeiras são adaptadas à realidade ${ }^{12}$, enquanto as segundas não são abandonadas em caso de desapontamento, isto é elas são estabilizadas de maneira contra-fática ${ }^{13}$.

Entretanto as expectativas de um indivíduo têm que ser adequadas às expectativas de outros, de modo que estas expectativas alheias também contribuem para criar a complexidade e a contingência ${ }^{14}$. Contudo, a aceitação das perspectivas dos outros permite uma expansão da capacidade de percepção, o que gera uma dupla contingência, já que o outro também pode se enganar ou se desapontar, e também porque a confirmação da expectativa de um pode ser o desapontamento de outro, o que é trabalhado por meio de expectativas de expectativas (Erwartungen von Erwartungen) ${ }^{15}$.

Estas expectativas de expectativas também podem gerar um desapontamento. Para lidar com um limite de desapontamento das expectativas normativas é necessário que estas sejam orientadas de uma maneira tal, que possam ser bem sucedidas. Esta orientação se desenvolve por meio da institucionalização de expectativas de comportamento, em que há uma orientação pela presunção de expectativas de expectativas de terceiros ${ }^{16}$.

Este mecanismo da institucionalização é necessário, tendo em vista a capacidade reduzida de atenção que os seres humanos $\operatorname{possuem}^{17}$ e a institucionalização se beneficia da vantagem que é oferecida pela instituição: não tanto a criação do consenso, mas em

\footnotetext{
11 „Unter Komplexität wollen wir verstehen, daß es stets mehr Möglichkeiten gibt, als aktualisiert werden können. Unter Kontingenz wollen wir verstehen, daß die angezeigten Möglichkeiten weiteren Erlebens auch anders ausfallen können, als erwartet wurde; daß die Anzeige mithin täuschen kann, indem sie auf etwas verweist, das nicht ist oder wider Erwarten nicht erreichbar ist oder, wenn man die notwendigen Vorkehrungen für aktuelles Erleben getroffen hat (zum Beispiel hingegangen ist), nicht mehr da ist. Komplexität heißt also praktisch Selektionszwang, Kontingenz heißt praktisch Enttäuschungsgefahr und Notwendigkeit des Sicheinlassens auf Risiken“ (LUHMANN, Niklas. Rechtssoziologie. 3. ed. Opladen: Westdeutscher, 1987, p. 31).

12 „Als kognitiv werden Erwartungen erlebt und behandelt, die im Falle der Enttäuschung an die Wirklichkeit angepaßt werden. Für normative Erwartungen gilt das Gegenteil: das man sie nicht fallenläßt, wenn jemand ihnen zuwiderhandelt" (LUHMANN, Niklas. Rechtssoziologie. 3. ed. Opladen: Westdeutscher, 1987, p. 42)

13 „Normen sind demnach kontrafaktisch sabilisierte Verhaltenserwartungen“ (LUHMANN, Niklas. Rechtssoziologie. 3. ed. Opladen: Westdeutscher, 1987, p. 42 [grifo no original])

${ }^{14}$ LUHMANN, Niklas. Rechtssoziologie. 3. ed. Opladen: Westdeutscher, 1987, p. 32.

${ }^{15}$ LUHMANN, Niklas. Rechtssoziologie. 3. ed. Opladen: Westdeutscher, 1987, p. 32 e ss..

16 „Normative Erwartungen können natürlich nicht beliebig mit Enttäuschungen belastet werden, und erst recht sind den strukturell erzeugten, laufenden Enttäuschungen Grenzen der Erträglichkeit gesetzt. Im großen und ganzen müssen normative Erwartungen so dirigiert werden, dass sie Erfolg haben können. Den Komplex von Mechanismen, der dies bewirkt, wollen wir unter dem Begriff der Institutionalisierung von Verhaltenserwartungen erörtern. Damit soll der Umfang bezeichnet werden, in dem Erwartungen auf unterstellbare Erwartungserwartungen Dritter gestützt werden können“" (LUHMANN, Niklas. Rechtssoziologie. 3. ed. Opladen: Westdeutscher, 1987, pp. 64-65 [grifo no original]).

${ }^{17}$ LUHMANN, Niklas. Rechtssoziologie. 3. ed. Opladen: Westdeutscher, 1987, p. 68.
} 
especial a simplificação que este produz ${ }^{18}$. É dentro deste contexto, segundo a teoria de Luhmann, que o direito desempenha sua função, isto é, a seleção de expectativas normativas que podem ser generalizadas de maneira congruente ${ }^{19}$.

Mesmo não se reconhecendo a função do direito apontada por Luhmann como sendo a principal função do direito, parece-nos claro que o direito deve promover uma redução das possibilidades de desapontamento das expectativas normativas, de modo a promover uma estabilidade social. Para tanto, é de se colocar em destaque também a função da a dogmática jurídica - que busca operacionalizar o ordenamento jurídico - que é orientada à decidibilidade de conflito com um mínimo de perturbação social ${ }^{20}$.

Esta é uma forma de abordagem que manifesta uma expressão da idéia de cálculo com referência à relação custo-benefício, em que as condições sociais são levadas em consideração para a decidibilidade dos $\operatorname{conflitos}^{21}$. Neste sentido, a dogmática jurídica aponta para uma constante necessidade de decisão - sempre tomando este cálculo como pressuposto -, de modo que a positividade do direito passa a residir não só no ato que estabelece uma lei, mas em sua constante prática ${ }^{22}$.

No processo decisório, destaca-se um elemento que ocupa um papel central: a interpretação. Este elemento será objeto de debate adiante ${ }^{23}$, mas convém desde já analisar a questão de a interpretação considerar as conseqüências da decisão, já que os conflitos

18 „Die Funktion von Institutionen liegt daher weniger in der Beschaffung als in der Ökonomie des Konsenses und die Ersparnis wird hauptsächlich dadurch erreicht, dass der Konsens im Erwarten von Erwartungen vorweggenommen wird, kraft Unterstellung fungiert und dann normalerweise gar nicht mehr konkret agefragt werden muß“ (LUHMANN, Niklas. Rechtssoziologie. 3. ed. Opladen: Westdeutscher, 1987, pp. 67-68).

19 „Die in diesem Sinne kongruent generalisierten normativen Verhaltenserwartungen wollen wir als das Recht eines sozialen Systems bezeichnen. Das Recht leistet selektive Kongruenz und bildet dadurch eine Struktur soziale systeme.

So definiert, wird das Recht funktional und selektiv begriffen - also nicht durch seinsähnlich vorgegebene Urqualität des ,Sollens' und nicht durch einen bestimmten faktischen Mechanismus, zum Beispiel, staatliche Sanktion. (...)

Die Funktion des Rechts liegt demnach in seiner Selektionsleistung, in der Auswahl von Verhaltenserwartungen, die sich in alle drei Dimensionen [temporal, material e social] generalisieren lassen“" (LUHMANN, Niklas. Rechtssoziologie. 3. ed. Opladen: Westdeutscher, 1987, pp. 99-100 [grifo no original, nota de rodapé omitida]).

${ }^{20}$ FERRAZ JR., Tercio Sampaio. Introdução ao estudo do direito: técnica, decisão, dominação. 3. ed. São Paulo: Atlas, 2001, p. 86.

${ }^{21}$ FERRAZ JR., Tercio Sampaio. Introdução ao estudo do direito: técnica, decisão, dominação. 3. ed. São Paulo: Atlas, 2001, p. 86.

22 „Das Kriterium liegt nicht in der ,Rechtsquelle', nicht in einmaligen Akt der Entscheidung, sondern im laufenden aktuellen Rechtserleben. Positiv gilt Recht nicht schon dann, wenn dem Rechtserleben ein historischer Akt der Gesetzgebung in Erinnerung ist - dessen Geschichtlichkeit kann traditionalem Rechtsdenken gerade als Symbol der Unabänderlichkeit dienen -, sondern nur, wenn das Recht als kraft dieser Entscheidung geltend, als Auswahl aus anderen Möglichkeiten und somit als abänderbar erlebt wird. Das historische Neue und Riskante der Positivität des Rechts ist die Legalisierung von Rechtsänderungen" (LUHMANN, Niklas. Rechtssoziologie. 3. ed. Opladen: Westdeutscher, 1987, p. 209 [grifo no original]).

${ }^{23}$ Vide o Capítulo 4. 
devem ser decididos com um mínimo de perturbação social. Isto é, por meio desta visão, a interpretação não deve se justificar somente por sua fundamentação formal, mas também pelos efeitos concretos que serão produzidos ${ }^{24}$.

Quando as conseqüências que geram um mínimo de perturbação social surgem da justificação formal sem maior conflito, esta não é uma questão que se coloca. Esta também não é uma questão relevante, se o órgão que tem competência para a interpretação, também tem competência para rever a própria norma - o que poderia ocorrer, por exemplo, caso em um ordenamento alinhado a common law, a corte mais elevada não ficasse vinculada aos seus próprios precedentes ${ }^{25}$.

Todavia, quando a justificação formal parece apontar para uma decisão que não geraria a pacificação social, surge a questão, que em certo sentido aponta para um confronto entre a validade (isto é, a pertinência de uma norma ao ordenamento ${ }^{26}$ ) e a eficácia (possibilidade de produção de efeitos pela norma ${ }^{27}$ ). Como tentativa de conciliação para este conflito, MacCormick aponta que a qualidade de uma decisão não depende somente de sua justificação, mas também dos efeitos que ela produz ${ }^{28}$.

Neste ponto inicial do presente trabalho, esta é uma questão que deve ser colocada, mas que ainda não reúne todas as condições para a sua resposta, uma vez que sua análise pressupõe um maior debate a respeito da hermenêutica jurídica, que será objeto de debate específico adiante. Além de se ter esta questão em mente, neste momento pode-se retomar a definição inicial de direito, que, ao ser adotada como referência, permitirá o desenvolvimento do estudo. Este conceito inicial de direito (em alusão a "direito objetivo")

\footnotetext{
${ }^{24}$ Esta já era uma das questões abordadas em um dos textos fundadores da análise econômica de direito na vertente da Escola de Chicago: "It would therefore seem desirable that the courts should understand the economic consequences of their decisions and should, insofar as this is possible without creating too much uncertainty about the legal position itself, take these consequences into account when making their decisions" (COASE, R. H.. The problem of social cost, in: Journal of Law and Economics, Vol. 3, Outubro de 1960, p. 19).

${ }^{25}$ Em outras palavras, esta é uma questão que só se coloca levando em consideração à conformação de um determinado ordenamento jurídico: "the relation of law-making and application of law is defined in the legal rules and any discussion of it must, therefore be relative to concrete legal systems or types of legal systems" (WRÓBLEWSKI, Jerzy. The judicial application of law. Dordrecht: Kluwer, 1992, p. 316).

${ }^{26}$ FERRAZ JR., Tercio Sampaio. Introdução ao estudo do direito: técnica, decisão, dominação. 3. ed. São Paulo: Atlas, 2001, p. 199.

${ }^{27}$ FERRAZ JR., Tercio Sampaio. Introdução ao estudo do direito: técnica, decisão, dominação. 3. ed. São Paulo: Atlas, 2001, p. 199.

28 "It ignores the extent to which the nature and quality of decisions and acts themselves constituted by the consequences the decider intents, foresees, or hopes to bring out. Also, more seriously, it ignores the extent to which both prudence and responsibility to one's fellows requires that one give serious thought to the foreseeable outcomes of one's acts and decisions before finally acting or deciding" (MACCORMICK, Neil. Rhetoric and the rule of law: a theory of legal reasoning, p. 102).
} 
se refere ao entendimento atual, de que o direito é um instrumento voltado à decidibilidade de conflitos com um mínimo de perturbação social.

Cabe agora oferecer breve estudo conceitual da economia, o que se fará a seguir.

\subsection{Economia}

Se uma definição de "direito" é alvo de controvérsias, uma conceituação de "economia" é uma tarefa menos árdua de se realizar. Atualmente há um consenso entre os manuais de economia a respeito do que venha a ser "economia". Destaquem-se alguns exemplos:

"Economics is the study of how people allocate their limited resources in an attempt to satisfy their unlimited wants. As such, economics is the study of how people make choices"29;

"The first step in understanding economics is to form an idea of its domain. In other words, what makes something a subject of economic investigation? Or, which is almost the same thing, what is an economic good? (...) Everything which is both scarce and desirable is an economic $\operatorname{good}^{\prime 30}$;

“The management of society's resources is important because resources are scarce. Scarcity means that society has limited resources and therefore cannot give every member everything he or she wants, a society cannot give every individual the highest standard of living to which he or she might aspire.

Economics is the study of how society manages its scarce resources" ${ }^{31}$;

"Economics is the study of how individuals and societies choose to use the scarce resources that nature and previous generations have provided. The key word in this definition is choose. Economics is a behavioural, or

\footnotetext{
${ }^{29}$ MILLER, Roger LeRoy. Economics today. 15. ed. Boston: Addison-Wesley, 2010, p. 2.

${ }^{30}$ WITZTUM, Amos. Economics: an analytical introduction. Oxford: Oxford, 2005, p.8.

${ }^{31}$ MANKIW, N. Gregory. Principle of economics. 3.ed. Mason: Thomson, 2004, p. 4.
} 
social, science. In large measure it is the study of how people make choices. The choices that people make, when added up, translate into societal choices" 32 (grifo no original).

Analisando estas definições é possível perceber que há um destaque para o fato de determinados bens serem escassos para atender a satisfação de todos os indivíduos e que, desta forma, os indivíduos - e conjuntamente a sociedade - têm que tomar decisões para satisfazer suas necessidades. Como as decisões tomadas pela sociedade são analisadas a partir da decisão do indivíduo, a análise do comportamento deste torna-se de central importância para a economia ${ }^{33}$. Mesmo uma abordagem de "economia" por sua função, como o faz a teoria de Luhmann, acaba por colocar a questão da escassez de bens em destaque, uma vez que a existência desta escassez de bens é a origem da função da economia $^{34}$.

Para a análise do indivíduo, a teoria econômica pressupõe que o mesmo seja racional. Enquanto anteriormente esta racionalidade era entendida como sendo ilimitada pela suposta capacidade das pessoas considerarem todos os aspectos envolvidos, bem como todas as conseqüências de uma decisão, de modo a poder agir de maneira sempre consistente -, a teoria econômica mais recente passou a considerar que, embora possa agir racionalmente, o indivíduo possui, de fato, apenas uma racionalidade limitada ${ }^{35}$.

\footnotetext{
${ }^{32}$ CASE, Karl E.; FAIR, Ray C.. Principles of economics. 7. ed. Nova Jersey: Pearson, 2004, p. 2.

33 "Modern economics, however, is fundamentally an individualistic theory. That is to say, it is a theory that is based almost entirely on the analysis of the behaviour of a single individual and his, or her, interaction with others. Any group analysis (...) are all viewed as a consequence of complex individuals' interactions" (WITZTUM, Amos. Economics: an analytical introduction. Oxford: Oxford, 2005, p.30). Destaque-se também o proposto por Posner: "economics is the science of rational choice in a world - our world - in which resources are limited in relation to human wants. The task of economics, so defined, is to explore the implication of assuming that man is a rational maximizer of his ends in life, his satisfactions - what we shall call his 'self-interest"” (POSNER, Richard A.. Economic analysis of law. 7. ed. Nova Iorque: Aspen, 2007, p. 3 [notas de rodapé omitidas]).

34 „Mit dem Vermehren zeitbeständiger, lagerfähiger Güter nimmt daher auch die Knappheit zu; und es muß ein sozialer Mechanismus erfunden werden, der eine zukunftsstabile Vorsorge mit je gegenwärtigen Verteilungen verknüpft. Das ist Funktion der Wirtschaft.

Formal gesehen orientiert sich alles Wirtschaften also an Knappheit. Der Bezug auf Knappheit reicht jedoch als Funktionsangabe nicht aus. Dies ergibt sich schon daraus, dass eine voll monetarisierte Wirtschaft es nicht nur mit einer, sondern mit zwei Knappheiten zu tun hat: mit der weltbedingten Knappheit der Güter und Leistungen und mit der artifiziellen Knappheit des Geldes. Dies hatten wir oben ,Codierung' genannt. Die Funktion der Wirtschaft muß deshalb durch die Konditionierung dieser beiden Beziehungen zwischen diesen beiden Knappheiten, vor allem also durch Preise, erfüllt werden“ (LUHMANN, Niklas. Die Wirtschaft der Gesellschaft. Frankfurt am Main: Suhrkamp, 1994, p. 64 [grifo no original]).

${ }^{35}$ MILLER, Roger LeRoy. Economics today. 15. ed. Boston: Addison-Wesley, 2010, pp. 9 e 10.
} 
Entretanto, estes estudos pressupondo a racionalidade limitada do indivíduo ainda estão em seu início, não tendo ainda repercutido profundamente na teoria econômica ${ }^{36}$.

Com relação a esse aspecto, é possível encontrar, eventualmente, na literatura econômica alguma referência à teoria weberiana da racionalidade ${ }^{37}$, em especial com relação à diferenciação entre Zweckrationalität e Wertrationalität ${ }^{38}$. Entretanto, outra definição weberiana não é mencionada pelos manuais, apesar da definição que estes utilizam se aproximar daquela. Trata-se do próprio conceito de economia, que em parte utiliza o conceito de Zweckrationalität. Confira-se o conceito exposto por Weber:

"Die Vergemeinschaftungen haben ihrer ganz überwiegenden Mehrzahl nach irgendwelche Beziehungen zur Wirtschaft. Unter Wirtschaft soll hier nicht, wie ein unzweckmäßiger Sprachgebrauch will, jedes zweckrational angelegte Handeln verstanden werden. Ein nach den Lehren irgendeiner Religion zweckmäßig eingerichtetes Gebet um ein inneres 'Gut' ist für uns kein Akt des Wirtschaftens. Auch nicht jedes Handeln oder Schaffen, welches dem Prinzip der Sparsamkeit folgt. Nicht nur ist eine, noch so bewußt bei einer Begriffsbildung geübte, Denkökonomie gewiß kein Wirtschaften, sondern auch etwa die Durchführung des künstlerischen Prinzips der 'Oekonomie der Mittel' hat mit Wirtschaften nichts zu tun und ist, an Rentabilitätsmaßstäben gemessen, ein oft höchst unökonomisches Produkt immer erneuter vereinfachender Umschaffensarbeit. Und ebenso ist die Befolgung der universellen technischen Maxime des 'Optimum': relativ größter Erfolg mit geringstem Aufwand, rein an sich noch nicht Wirtschaften, sondern: zweckrational orientierte Technik. Von Wirtschaft wollen wenigstens wir hier vielmehr nur reden, wo einem

\footnotetext{
${ }^{36}$ MILLER, Roger LeRoy. Economics today. 15. ed. Boston: Addison-Wesley, 2010, p. 10. Para Posner, uma forma teórica de lidar com esta limitação é entender que ela seria uma forma de custo de absorver e utilizar a informação: "Rational maximization should not be confused with conscious calculation. Economics is not a theory about consciousness. Behavior is rational when it conforms to the model of rational choice, whatever the state of the mind of the chooser (...) Nor is perfect rationality assumed; rational-choice theory allows us to assume that rationality is 'bounded' because of human cognitive limitations, although another way to think of those limitations is as costs of absorbing and using information". (POSNER, Richard A. Economic analysis of law. 7. ed. Nova Iorque: Aspen, 2007, p. 3)

${ }^{37}$ WITZTUM, Amos. Economics: an analytical introduction. Oxford: Oxford, 2005, p. 41.

38 „Wie jedes Handeln kann auch das soziale Handeln bestimmt sein. 1. zweckrational: durch Erwartungen des Verhaltens von Gegenständen der Außenwelt und von anderen Menschen und unter Benutzung dieser Erwartungen als ,Bedigungen' oder als ,Mittel' für rational, als Erfolg, erstrebte und abgewogene eigne Zwecke, 2. wertrational: durch bewußten Glauben an den - ethischen, ästethischen , religiösen oder wie immer sonst zu deutenden - unbedingten Eigenwert eines bestimmten Sichverhaltens rein als solchen und unabhängig vom Erfolg“ (WEBER, Max. Wirtschaft und Gesellschaft: Grundriss der verstehenden Soziologie. 5. ed. Tübingen: Mohr Siebeck, 1980, p. 12). Para Weber, a orientação da ação social também poderia ocorrer por meio da afetividade ou da tradição (WEBER, Max. Wirtschaft und Gesellschaft: Grundriss der verstehenden Soziologie. 5. ed. Tübingen: Mohr Siebeck, 1980, p. 12).
} 
Bedürfnis oder einem Komplex solcher, ein, im Vergleich dazu, nach der Schätzung des Handelnden, knapper Vorrat von Mitteln und möglichen Handlungen zu seiner Deckung gegenübersteht und dieser Sachverhalt Ursache eines spezifisch mit ihm rechnenden Verhaltens wird. Entscheidend ist dabei für zweckrationales Handeln selbstverständlich: daß diese Knappheit subjektiv vorausgesetzt und das Handeln daran orientiert ist" (nosso grifo $)^{39}$

Nesta definição já se pode perceber os elementos principais que são encontrados nas definições contemporâneas. É de se destacar que no início do século XX, quando Weber propôs sua definição, ainda era comum encontrar o pensamento oposto na economia, isto é, que a economia, ao invés de lidar com a escassez, deveria lidar com a promoção da fartura ${ }^{40}$. Contudo, naquela definição, Weber tratava a economia como uma abordagem relativa ao que se apresenta como escasso em relação às necessidades, apontando também que esta escassez serve de orientação para a ação do indivíduo, o que tem sido apontado como traço característico comum das definições contemporâneas, como acima destacado.

Feita esta observação, é conveniente finalmente mencionar uma divisão da economia que é feita usualmente, isto é a diferenciação entre duas grandes áreas, a macroeconomia e a microeconomia. Nesta divisão, a microeconomia é a área que se ocupa com o estudo dos indivíduos, das empresas, bem como com as outras unidades envolvidas na economia ${ }^{41}$. De outro lado, a macroeconomia seria a responsável pela análise da economia como um todo, isto é, seu objeto não se restringiria ao comportamento de um indivíduo, mas ao de uma coletividade, de modo que questões, como o comportamento da taxa de desemprego e variações da renda nacional ou da produção nacional, recairiam sobre sua área ${ }^{42}$. Entretanto, deve-se destacar que esta diferenciação entre macroeconomia

\footnotetext{
39 WEBER, Max. Wirtschaft und Gesellschaft: Grundriss der verstehenden Soziologie. 5. ed. Tübingen: Mohr Siebeck, 1980, p. 199.

${ }^{40}$ COOTER, Robert; RAPPOPORT, Peter. Were the ordinalists wrong about welfare economics?, in: Journal of Economic Literature, Vol. 22, junho de 1984, p. 512; HOVENKAMP, Herbert. The first great law \& economics movement, in: Stanford Law Review, Vol. 42, N 4, abril de 1990, pp. 1033-1034.

41 "Microeconomics deals with the functioning of individual industries and the behavior of individual economic decision-making units: business firms and households" (CASE, Karl E.; FAIR, Ray C.. Principles of economics. 7. ed. Nova Jersey: Pearson, 2004, p. 6); "Microeconomics is the part of economic analysis that studies decision making undertaken by individuals (or households) and by firms. It is like looking through a microscope to focus on the small parts of our economy" (MILLER, Roger LeRoy. Economics today. 15. ed. Boston: Addison-Wesley, 2010, p. 3).

42 "Macroeconomics is the part of economic analysis that studies the behaviour of the economy as a whole. It deals with economywide phenomena such as changes in unemployement, in the general price level, and in
} 
e microeconomia é alvo de questionamentos, dado que com os avanços da microeconomia, seria possível estudar a macroeconomia a partir das ferramentas da primeira ${ }^{43}$. Não obstante, trata-se de uma diferenciação que ainda é extremamente difundida.

national income" (MILLER, Roger LeRoy. Economics today. 15. ed. Boston: Addison-Wesley, 2010, p. 3); "Macroeconomics looks at the economy as a whole. Instead of trying to understand what determines the output of a single firm or industry or the consumption patterns of a single household or group of households, macroeconomics examines the factors that determine national output, or national product" (CASE, Karl E.; FAIR, Ray C.. Principles of economics. 7. ed. Nova Jersey: Pearson, 2004, p. 6).

43 "Recent developments in microeconomics theory suggest that there may not be a need to separate macroeconomics from microeconomic analysis and that we have sufficient tools to incorporate both money and government into our micro-models" (WITZTUM, Amos. Economics: an analytical introduction. Oxford: Oxford, 2005, p. 8) 


\section{DIREITO E ECONOMIA: BREVE ABORDAGEM HISTÓRICA}

Atualmente a menção à análise econômica do direito traz a imediata referência à Escola de Chicago e a particularidades de seu método, que tem despertado crescente interesse. Contudo, deve-se destacar que anteriormente houve outras linhas teóricas que chegaram a promover uma forma de análise econômica do direito. Ainda que não se possa precisar qual foi exatamente o precursor desta análise ${ }^{44}$, é de se destacar que há um conjunto de autores, que muito antes da década de 1960 - marco normalmente associado ao surgimento da análise econômica do direito - empreendiam um estudo do direito a partir de princípios econômicos. Com efeito, antes de se expor a corrente teórica que atualmente desperta maior interesse no debate jurídico, convém proceder a uma breve análise das principais linhas teóricas que orientavam o debate do final do século XIX e do começo do século XX.

\subsection{O processo legislativo e a economia}

3.1.1 O processo legislativo e a economia: a análise econômica do direito na virada do século XX

Um relevante marco histórico da teoria econômica, a ser inicialmente lembrado, remonta à década de 70 do século XIX. Trata-se da colocação do conceito de utilidade marginal no centro da pesquisa da economia, evento que usualmente é denominado como "revolução marginalista" "45 O motivo para a pouca importância anteriormente dada à teoria da utilidade se refere ao chamado "paradoxo do valor", segundo o qual a água era um bem de alto valor de uso, mas de baixo preço, enquanto o contrário se verificava com os diamantes, de modo que o preço de um item não conseguia ser explicado a partir de sua utilidade $^{46}$. A percepção da importância da teoria da utilidade vem a partir da teoria de Jevons que, em 1871, em vez de associar o preço à utilidade total, propôs sua inter-relação com a utilidade marginal, o que segundo seus estudos se justificava, dado que um

\footnotetext{
${ }^{44}$ A respeito de qual é o ínicio de uma análise econômica do direito, não há um consenso na teoria, com alguns apontando os estudos de Beccaria e de Bentham como precursores (Cf. SHAVELL, Steven. Foundations of economic analysis of law. Cambridge: Harvard, 2004, p. 4)

${ }^{45}$ COOTER, Robert; RAPPOPORT, Peter. Were the ordinalists wrong about welfare economics?, in: Journal of Economic Literature, Vol. 22, junho de 1984, p. 507.

${ }^{46}$ COOTER, Robert; RAPPOPORT, Peter. Were the ordinalists wrong about welfare economics?, in: Journal of Economic Literature, Vol. 22, junho de 1984, p. 510.
} 
equilíbrio nas trocas pressuporia uma igualdade na proporção da utilidade marginal e na proporção do preço para um determinado bem ${ }^{47}$.

Segundo o conceito de utilidade marginal, a utilidade que uma pessoa deriva de um bem depende, além da necessidade dela, da quantidade do referido bem de que ela dispõe, isto é, a primeira unidade de um bem costuma trazer maior satisfação a um consumidor do que as seguintes ${ }^{48}$. Assim, uma pessoa obterá cada vez menos utilidade de um bem, quanto maior for a quantidade do determinado bem que a referida pessoa tiver e, como corolário, quanto maior for a quantidade possuída de um bem, menor será a percepção da perda de uma unidade do referido bem para a mesma pessoa. Deste modo, o acréscimo de utilidade que a obtenção de uma unidade a mais confere, será cada vez menor $^{49}$.

Por meio deste raciocínio, a teoria econômica passava a justificar a importância de transferência de riqueza, ainda que involuntária, dos mais abastados para os menos favorecidos. A justificativa para tal conduta residiria no fato de que uma unidade de dinheiro seria de pouca importância para um bilionário, enquanto que a mesma unidade poderia ser de vital importância para uma pessoa carente de bens materiais, de modo que se verificaria um aumento no bem estar geral (total welfare) ${ }^{50}$. Levando esta lógica ao extremo, o máximo do bem estar geral de uma sociedade, que poderia ser atingido, ocorreria quando a utilidade marginal de um bem fosse a mesma de uma pessoa para a outra; isto é, aquele máximo seria atingido, quando a valoração da utilidade do bem acrescido a uma pessoa fosse igual à valoração da perda de utilidade marginal pela diminuição da quantidade de um determinado bem ${ }^{51}$.

Neste sentido, a preocupação presente na análise econômica deste período na Europa, com destaque para a Alemanha - e que orientou o debate nos Estados Unidos -, não se pautava tanto pelo tema da escassez, mas sim pela prosperidade ou com a riqueza $(\text { wealth })^{52}$. Com este foco na prosperidade e na distribuição dos bens, teóricos da análise

47 COOTER, Robert; RAPPOPORT, Peter. Were the ordinalists wrong about welfare economics?, in: Journal of Economic Literature, Vol. 22, junho de 1984, p. 510.

${ }^{48}$ NUSDEO, Fábio. Curso de economia: introdução ao direito econômico. 3. ed. São Paulo: RT, 2001, p. 241.

${ }^{49}$ MILLER, Roger LeRoy. Economics today. 15. ed. Boston: Addison-Wesley, 2010, p. 527.

${ }^{50}$ HOVENKAMP, Herbert. The first great law \& economics movement, in: Stanford Law Review, Vol. 42, $\mathrm{N}^{\circ}$ 4, abril de 1990, p. 1001.

${ }^{51}$ HOVENKAMP, Herbert. The first great law \& economics movement, in: Stanford Law Review, Vol. 42 , $\mathrm{N}^{\circ}$ 4, abril de 1990, p. 1001.

52 COOTER, Robert; RAPPOPORT, Peter. Were the ordinalists wrong about welfare economics?, in: Journal of Economic Literature, Vol. 22, junho de 1984, p. 512; HOVENKAMP, Herbert. The first great law \& economics movement, in: Stanford Law Review, Vol. 42, N 4, abril de 1990, pp. 1033-1034. 
econômica do direito, como Stammler (que destacava a chamada "questão social"), passam, pois, a se interessar pela promoção da distribuição da riqueza como sendo papel do Estado $^{53}$, o que justificaria uma série de medidas, desde a fixação de um salário mínimo, até a instituição de padrões de saúde, passando pela promoção de educação estatal $^{54}$ ou até mesmo uma reorientação dos meios de produção.

Destaque-se que estas eram medidas a serem implementadas precipuamente por meio da legislação, não se relacionando a uma mera alteração da interpretação dos dispositivos positivados. Dois fatores podem ser destacados como explicação para este maior interesse que a legislação despertava, se comparado com o interesse pela aplicação do direito pelo Judiciário.

$\mathrm{O}$ primeiro destes fatores se refere à concepção política que os economistas daquela corrente adotavam, ao manifestarem uma forma de pensamento liberal $^{55}$ - no sentido empregado no debate norte americano -, e conseqüentemente desenvolverem uma posição mais cética em relação ao papel do mercado como fonte de distribuição de riqueza $^{56}$, de modo que a presença Estatal seria, desse modo, justificada.

Já o segundo fator se relaciona também à concepção política, mas à sua tentativa de neutralização. Partindo-se da teoria clássica da divisão dos poderes, no século XIX havia a defesa da aceitação da política no âmbito do Legislativo e do Executivo, ao passo que no Judiciário a orientação defendida voltava-se para a sua neutralização política ${ }^{57}$. Como consequência desta neutralização política do Judiciário, a legislação passa a ocupar um papel privilegiado como fonte do direito ${ }^{58}$, o que se insere no debate da positivação do

\footnotetext{
53 "The goal sought is to make more easy practical measures to promote welfare - practical measures which statesmen may build upon the work of the economist" (PIGOU, A. C.. The economics of welfare. 4. ed. Londres: Macmillan, 1952, p. 10).

54 "This concept of welfare helps to explain the high degree of statism among the economists of the material welfare school, who comprised the first great law \& economics movement. They were Progressives, who believed that social welfare could be increased by minimum wage laws, graduated income taxes, subsidized public education, welfare payments to the poor, taxes on monopoly profits, and other devices by which the relatively wealthy were required to finance the provision of goods and services to the relatively impoverished. Health or safety regulation could also be justified as taxes on wealthy producers for the benefit of poorer consumers. The beneficiaries of these forced transfers were perceived to gain more utility than the involuntary grantors lost" (HOVENKAMP, Herbert. The first great law \& economics movement, in: Stanford Law Review, Vol. 42, º 4, abril de 1990, p. 1002 [nota de rodapé omitida]).

55 "The first great law \& economics movement grew out of a reaction against emergent neoclassicism and a search for alternatives" (HOVENKAMP, Herbert. The first great law \& economics movement, in: Stanford Law Review, Vol. 42, N 4, abril de 1990, p. 994).

${ }^{56}$ HOVENKAMP, Herbert. The first great law \& economics movement, in: Stanford Law Review, Vol. 42, $\mathrm{N}^{\circ}$ 4, abril de 1990, p. 995.

${ }^{57}$ FERRAZ JR., Tercio Sampaio. Introdução ao estudo do direito: técnica, decisão, dominação. 3. ed. São Paulo: Atlas, 2001, p. 73.

${ }^{58}$ FERRAZ JR., Tercio Sampaio. Introdução ao estudo do direito: técnica, decisão, dominação. 3. ed. São Paulo: Atlas, 2001, pp. 73-74.
} 
direito, isto é, a percepção da mutabilidade do direito, que viria a ser estabelecido por meio de decisões.

Neste sentido, a legislação - como uma forma de decisão a respeito do ordenamento jurídico - era entendida como o instrumento adequado para promover a alteração do direito, que de acordo com a concepção exposta por Stammler deveria seguir as alterações nas relações econômicas ${ }^{59}$. Isto é, o direito seria apenas um instrumento que deveria ser orientado pelas "forças naturais" do fenômeno econômico ${ }^{60}$. Entretanto, o estudo da economia não deveria ser considerado por si só, devendo ser empreendido em conjunto com a análise da "vida social" (soziales Leben) ${ }^{61}$. Desse modo, faria sentido abordar a "economia social" (soziale Wirtschaft) ${ }^{62}$, que desse modo atenderia ao ponto relevante para as ciências sociais, isto é, a "questão social" (soziale Frage) ${ }^{63}$.

Na visão de Stammler, esta questão seria abordada por meio de uma abordagem histórica materialista, que seria oferecida pelo socialismo alemão da época ${ }^{64}$, cuja teoria mais desenvolvida seria a oferecida por Engels ${ }^{65}$. Segundo este entendimento, haveria um conflito entre o modo de produção e o modo de aquisição que estavam instituídos naquele

59 „Die wirtschaftlichen Verhältnisse bedingen die Gestaltung der Rechtsordnung. Für die letztere gibt es keine selbständigen bestimmenden Gründe, die von der sozialen Wirtschaft unabhängig wären; soziale Ideen und Bestrebungen sind nur Ausfluß und Widerschein von wirtschaftlichen Verhältnissen“ (STAMMLER, Rudolf. Wirtschaft und Recht nach der materialistischen Geschichtsauffassung: eine sozialphilosophische Untersuchung. 2. ed. Leipzig: Veit, 1906, p. 41).

60 „Das Recht aber ist nichts anders als ein menschlich gefertigtes Instrument; ein Werkzeug, das zur zweckmäßigen Leitung der den ökonomischen Phänomenen innewohnenden Naturkräfte dienen mag, das also ganz und gar von diesen letzteren abhängig ist, sich nach ihnen richten muß und durch sie notwendig bedingt wird“" (STAMMLER, Rudolf. Wirtschaft und Recht nach der materialistischen Geschichtsauffassung: eine sozialphilosophische Untersuchung. 2. ed. Leipzig: Veit, 1906, p. 43).

61 „Andererseits geht es auch nicht an, mit der durchgängig üblichen Art der politischen Ökonomie den Begriff der Wirtschaft als einen obersten Begriff zu behandeln und ihn in selbständiger Weise zur letzten Unterlage einer sozialwissenschaftlichen Forschung einzusetzen“ (STAMMLER, Rudolf. Wirtschaft und Recht nach der materialistischen Geschichtsauffassung: eine sozialphilosophische Untersuchung. 2. ed. Leipzig: Veit, 1906, p. 10).

62 „Auch hier ist statt dessen nötig, mit der Untersuchung bei dem Begriffe des sozialen Lebens selbst, als unserem letztem problematischen Gegenstande, zu beginnen; bei dessen grundlegender Analyse erst dem Rechte, wie der sozialen Wirtschaft ihre zutreffend Stellung in dem Ganzen des gesellschaftlichen Daseins der Menschen anzuweisen“ (STAMMLER, Rudolf. Wirtschaft und Recht nach der materialistischen Geschichtsauffassung: eine sozialphilosophische Untersuchung. 2. ed. Leipzig: Veit, 1906, p. 10).

${ }^{63}$ Das Ringen aber nach gesetzmäßiger Ausgestaltung des gesellschaftlichen Lebens ist da, es lässt sich nicht verdecken, noch übersehen, - es heißt: die soziale Frage“ (STAMMLER, Rudolf. Wirtschaft und Recht nach der materialistischen Geschichtsauffassung: eine sozialphilosophische Untersuchung. 2. ed. Leipzig: Veit, 1906, p. 6).

64 „Die bedeutsamste Einzelanwendung der materialistischen Geschichtsauffassung ist der moderne deutsche Sozialismus“ (STAMMLER, Rudolf. Wirtschaft und Recht nach der materialistischen Geschichtsauffassung: eine sozialphilosophische Untersuchung. 2. ed. Leipzig: Veit, 1906, p. 37).

65 „So kann man die Darstellung von Engels als die vollendetste und als die authentische Wiedergabe der Prinzipien des sozialen Materialismus behandeln“ (STAMMLER, Rudolf. Wirtschaft und Recht nach der materialistischen Geschichtsauffassung: eine sozialphilosophische Untersuchung. 2. ed. Leipzig: Veit, 1906, p. 36). 
momento ${ }^{66}$. O modo de produção não mais seria individual ou privado, passando a ser socializado, enquanto que o modo de aquisição continuaria privado. Neste sentido, seria necessário que o direito se adaptasse a essa nova realidade ${ }^{67}$. Assim, a legislação era o modo adequado para executar esta adequação do direito à economia, podendo deste modo instituir uma nova ordem jurídica ${ }^{68}$.

Mas não foi só na Alemanha que a corrente teórica que desenvolvia uma análise econômica do direito tinha um interesse predominante pela legislação. É de se destacar que, mesmo nos Estados Unidos, os teóricos que desenvolveram a primeira corrente norteamericana de análise econômica do direito, também manifestavam maior interesse pela legislação. Este maior interesse pelo processo legislativo em um local com um ordenamento jurídico baseado na common law e impregnado pela importância do precedente judicial - como os Estados Unidos - pode ser explicado também pela influência do pensamento continental europeu da Escola Histórica Alemã ${ }^{69}$, o que também ocorreu com o pensamento jurídico ${ }^{70}$.

Entretanto, deve-se destacar que esta corrente teórica obteve relativamente pouca repercussão no debate nos Estados Unidos. O motivo para tanto não se refere ao predomínio do interesse pela legislação, o que por si só era estranho ao pensamento norteamericano, em que um maior destaque do papel do Judiciário era considerado, mas principalmente a outro motivo.

A principal razão para a falta de influência nos Estados Unidos desta teoria resulta da concepção política que orientava aqueles teóricos da análise econômica do direito, há um século, que estavam preocupados em promover a intervenção do Estado, com a

\footnotetext{
66 „Es entsteht ein sozialer Konflikt zwischen der geänderten Wirtschaft und dem stehen gebliebenen Rechte. Im Mittelalter bestand private Produktion und private Aneignung; heute dagegen sozialisierte Produktion und trotzdem Privateigentum an den Produkten. Hier klafft ein Widerspruch zwischen Produktionsweise und Aneignungsweise" (STAMMLER, Rudolf. Wirtschaft und Recht nach der materialistischen Geschichtsauffassung: eine sozialphilosophische Untersuchung. 2. ed. Leipzig: Veit, 1906, p. 39).

67 „Sobald aber der Marxist einen solchen in Güte nicht löslichen Konflikt zwischen Wirtschaft und Recht deutlich und sicher erkennt, so ist es ihm selbstverständlich, daß das Recht nachgeben muß - zufolge der allgemeinen Gesetzmäßigkeit des sozialen Lebens“ (STAMMLER, Rudolf. Wirtschaft und Recht nach der materialistischen Geschichtsauffassung: eine sozialphilosophische Untersuchung. 2. ed. Leipzig: Veit, 1906, p. 43).

${ }^{68}$ „Die wissenschaftliche Erkenntnis der naturgesetzlichen Entwickelung unserer ökonomischen Phänomene weist zugleich den Weg und das Ziel, auf welches sie hindrängen, und das naturnotwendig erreicht werden wird: Die neue Rechtsordnung“ (STAMMLER, Rudolf. Wirtschaft und Recht nach der materialistischen Geschichtsauffassung: eine sozialphilosophische Untersuchung. 2. ed. Leipzig: Veit, 1906, p. 45).

${ }^{69}$ HOVENKAMP, Herbert. The first great law \& economics movement, in: Stanford Law Review, Vol. 42, $\mathrm{N}^{\circ} 4$, abril de 1990, p. 1056.

70 „Es gibt zwar deutliche Hinweise auf eine erhebliche Wirkung der historischen Schule und der deutschen Rechtswissenschaft des 19. Jahrhunderts auch in den USA“(REIMANN, Mathias. Historische Schule und Common Law: die deutsche Rechtswissenschaft des 19. Jahrhunderts im amerikanischen Rechtsdenken. Berlim: Duncker\&Humblot, 1993, p.11).
} 
finalidade de promover a distribuição de riquezas. Tendo em vista o anteriormente mencionado papel central da utilidade marginal e sua justificativa para a transferência forçada de riquezas, esta vertente de análise econômia passa aos poucos nos últimos anos do século XIX a ser criticada pela percepção de que nela haveria uma crescente influência do pensamento socialista ${ }^{71}$, o que contrastava com o pensamento dominante nos Estados Unidos, que já naquela época não nutria simpatia por esta concepção político-teórica.

Com efeito, os críticos anglo-saxões desta concepção, começam a buscar algum instrumento para promover uma teoria econômica alternativa, que não tivesse como objetivo promover a intervenção do Estado e a distribuição forçada de riquezas. Os fundamentos para esta teoria surgem na década de 30 do século $\mathrm{XX}$, com a chamada "revolução hicksiana" ou "revolução ordinalista"72. Segundo esta nova vertente, o pressuposto estabelecido na teoria econômica até então, segundo o qual seria possível fazer uma comparação interpessoal de utilidade marginal - e que justificaria a política de promoção de bem-estar e de distribuição de renda - não seria científico ${ }^{73}$. Esta falta de cientificidade se originaria no fato de que esta comparação interpessoal se fundamentaria em observações subjetivas sem possibilidade de demonstração ${ }^{74}$.

Segundo esta crítica, cada pessoa poderia saber o grau de utilidade que cada unidade lhe acrescenta, mas esta seria uma percepção meramente subjetiva. Desse modo, um observador externo, ao efetuar a comparação entre a variação da utilidade de cada unidade acrescentada - ou subtraída - do patrimônio de uma pessoa, não teria como efetuar uma comparação neutra, desvinculada do subjetivismo de cada uma das pessoas

\footnotetext{
${ }^{71}$ HOVENKAMP, Herbert. The first great law \& economics movement, in: Stanford Law Review, Vol. 42 , $\mathrm{N}^{\circ}$ 4, abril de 1990, p. 1057.

72 COOTER, Robert; RAPPOPORT, Peter. Were the ordinalists wrong about welfare economics?, in: Journal of Economic Literature, Vol. 22, junho de 1984, p. 507.

${ }^{73}$ HOVENKAMP, Herbert. The first great law \& economics movement, in: Stanford Law Review, Vol. 42, $\mathrm{N}^{\circ}$ 4, abril de 1990, pp. 1003-1004.

${ }^{74}$ Mesmo os que propunham uma comparação interpessoal de utilidades admitiam que o método não poderia ser demonstrado, mas o sustentavam com base em observações: "We do not, in short, and there is no reason why we should, start from a tabula rasa, binding ourselves to hold every opinion which the natural man entertains to be guilty until it is proved innocent. The burden is the other way. To deny this is to wreck, not merely Welfare Economics, but the whole apparatus of practical thought. On the basis of analogy, observation and intercourse, inter-personal comparisons can, as I think, properly be made; and, moreover, unless we have a special reason to believe the contrary, a given amount of stuff may be presumed to yield a similar amount of satisfaction, not indeed as between any one man and any other, but as between representative members of groups of individuals" (PIGOU, A. C.. The economics of welfare. 4. ed. Londres: Macmillan, 1952, pp. 850-851 [grifo no original]).
} 
envolvidas ${ }^{75}$. Deste modo, a teoria econômica não poderia fazer projeções, pois lhe faltaria o caráter científico para poder fazer prescrições ${ }^{76}$.

Para se livrar deste subjetivismo, a teoria econômica passou então a ter como requisito o critério de Pareto $^{77}$. Para atender este critério, uma determinada troca deve colocar ao menos um indivíduo em situação melhor do que a que se encontrava antes da ação ocorrer e ao mesmo tempo, a referida ação não pode deixar indivíduo algum em situação menos favorecida a que se encontrava anteriormente ${ }^{78}$. Deste modo, como ninguém se encontrará em situação inferior a que se encontrava antes, o critério de Pareto apresenta a vantagem de dispensar a necessidade de realização de uma comparação interpessoal.

Entretanto, como a maior parte das ações acabava resultando em prejuízo para alguém, o critério de Pareto se apresentava como pouco praticável ${ }^{79}$. Como alternativa, há o desenvolvimento do critério de Kaldor-Hicks, que vem a ser adotado na maior parte dos estudos teóricos da economia atualmente. Nicholas Kaldor, partindo do exemplo da revogação das leis que taxavam a importação do trigo para a Grã-Bretanha (as chamadas “Corn Laws") ${ }^{80}$ resume os efeitos que teriam decorrido da referida revogação ${ }^{81}$.

\footnotetext{
${ }^{75}$ HOVENKAMP, Herbert. The first great law \& economics movement, in: Stanford Law Review, Vol. 42 , $\mathrm{N}^{\circ} 4$, abril de 1990, p. 1035.

${ }^{76}$ ROBBINS, Lionel. Interpersonal comparisons of utility: a comment, in: The Economic Journal, Vol. 48, $\mathrm{N}^{\circ} .192$, dezembro de 1938 , p. 639 e ss.

${ }^{77}$ HOVENKAMP, Herbert. The first great law \& economics movement, in: Stanford Law Review, Vol. 42 , $\mathrm{N}^{\circ}$ 4, abril de 1990, p. 1037.

${ }^{78}$ CASE, Karl E.; FAIR, Ray C.. Principles of economics. 7. ed. Nova Jersey: Pearson, 2004,p. 241.

79 "Em quase qualquer política pública ou programa concebível há ganhadores e perdedores. A decisão governamental de controlar o preço de medicamentos 'beneficia' os usuários daqueles remédios e 'prejudica', presumivelmente, acionaistas, empregados e até consumidores de outros produtos. Impor novos e custosos critérios ambientais para licenciamento pode beneficiar os cidadãos de amanhã às expensas dos consumidores de hoje (que pagarão mais caros pelos produtos que, em última instância, remuneram a atividade da firma que agora deve arcar com novos custos). Uma política de encarecimento (por via de instituição de tributos indiretos) do preço do cigarro 'prejudica' os fumantes de hoje, e, eventualmente, beneficia os 'doentes' de amanhã (que talvez tenham acesso a mais hospitais públicos financiados pela arrecadação)". (GOLDBERG, Daniel. Poder de Compra e política antitruste. São Paulo: Singular, 2006, p. 40).
}

${ }^{80}$ Este exemplo havia sido desenvolvido em HARROD, R.F.. Scope and method of economics, in: The Economic Journal, Vol. 48, $\mathrm{N}^{\circ}$ 191, setembro de 1938, pp. 383-412.

81 "The effects of the repeal of the Corn Laws could be summarised as follows: (i) it results in a reduction in the price of corn, so that the same money income will now represent a higher real income; (ii) it leads to a shift in the distribution of income, so that some people's (i.e., the landlord's) incomes (at any rate in money terms) will be lower than before, and other people's incomes (presumably those of other producers) will be higher. Since aggregate money income can be assumed to be unchanged, if the landlords' income is reduced, the income of other people must be correspondingly increased. It is only as a result of this consequential change in the distribution of income that there can be any loss of satisfactions to certain individuals, and hence any need to compare the gains of some with the losses of others. But it is always possible for the Government to ensure that the previous income-distribution should be maintained intact: by compensating the 'landlords' for any loss of income and by providing the funds for such compensation by an extra tax on those whose incomes have been augmented. In this way, everybody is left as well off as before in his 
Por um lado, estes efeitos se manifestariam na redução do preço do trigo, o que teria por conseqüência que proporcionalmente a mesma quantia de dinheiro representaria um maior poder aquisitivo para todos os britânicos. Por outro lado, a revogação do tributo do trigo também levaria a uma mudança na distribuição de riqueza, isto é, a renda obtida e seu poder aquisitivo - seria menor para alguns (por exemplo os proprietários de terra, que se beneficiavam do preço do trigo mais elevado) e maior para outros (os outros produtores). No entanto, como poderia se presumir que a soma total de rendimento se manteria estável, seria possível que o governo instituísse alguma forma de taxa adicional para os outros proprietários, que promovesse uma compensação àqueles que se prejudicaram com a revogação do imposto original. Conseqüentente, no entender de Kaldor, em relação à situação original todos estariam estáveis no que se refere ao recebimento de proventos, mas todos apresentariam uma melhora em sua situação como consumidores.

Deste modo, Kaldor passa a considerar, então, que a possibilidade de haver compensação para todos os envolvidos poderia justificar, para o economista, uma determinada política, uma vez que não mais seria necessário demonstrar que sua aplicação não colocava indivíduo algum em situação inferior ${ }^{82}$. Como não competiria, assim, ao economista se pronunciar a respeito da conveniência da realização efetiva desta compensação, a verificação da mera possibilidade de haver a compensação seria suficiente para a teoria econômica ${ }^{83}$.

Assim, a teoria econômica deveria ser dividida em duas partes: a primeira seria relacionada à produção, enquanto a segunda enfocaria a distribuição ${ }^{84}$. Na primeira parte estariam compreendidas proposições como as que se referem ao aumento da produção agregada ou à estimulação da geração de empregos, de modo que o economista poderia

capacity as an income recipient; while everybody is better off than before in his capacity as a consumer" (KALDOR, Nicholas. Welfare propositions of economics and interpersonal comparisons of utility, in: The Economic Journal, Vol. 49, № 195, setembro de 1939, p. 550 [grifo no original]).

82 "In all cases, therefore, where a certain policy leads to an increase in physical productivity, and thus of aggregate real income, the economist's case for the policy is quite unaffected by the question of the comparability of individual satisfactions; since in all such cases it is possible to make everybody better off than before, or at any rate to make some people better off without making anybody worse off. There is no need for the economist to prove-as indeed he never could prove-that as a result of the adoption of a certain measure nobody in the community is going to suffer. In order to establish his case, it is quite sufficient for him to show that even if all those who suffer as a result are fully compensated for their loss, the rest of the community will still be better off than before" (KALDOR, Nicholas. Welfare Propositions of Economics and Interpersonal Comparisons of Utility, in: The Economic Journal, Vol. 49, $\mathrm{N}^{\circ}$ 195, setembro de 1939, p. 550 [grifo no original]).

${ }^{83}$ KALDOR, Nicholas. Welfare propositions of economics and interpersonal comparisons of utility, in: The Economic Journal, Vol. 49, $\mathrm{N}^{\circ} 195$, setembro de 1939, p. 550.

${ }^{84}$ KALDOR, Nicholas. Welfare propositions of economics and interpersonal comparisons of utility, in: The Economic Journal, Vol. 49, $\mathrm{N}^{\circ} 195$, setembro de 1939, p. 551. 
fazer previsões nesta área com maior grau de certeza ${ }^{85}$. Na segunda parte, contudo, o papel do economista se resumiria a analisar as vantagens e desvantagens de se empregar determinada política para se chegar a um fim político, sem que a teoria econômica pudesse prescrever uma determinada política ${ }^{86}$.

Estas observações de Kaldor são incorporadas por Hicks ao desenvolver o seu raciocínio a respeito da dificuldade das comparações interpessoais ${ }^{87}$. Hicks entende que as teorias anteriores, tomadas a partir do exemplo da obra de Pigou, teriam como uma etapa essencial para o desenvolvimento de seu argumento a necessidade de realizar as comparações interpessoais ${ }^{88}$. Para o mencionado autor, esta atividade seria como medir uma temperatura a partir de diversos termômetros, funcionando cada um deles com base em princípios diversos, sem que tenham uma necessária correlação ${ }^{89}$.

Para conseguir realizar esta tarefa, Hicks concebe três maneiras diferentes, sendo que duas delas acabariam por ser rejeitadas, pois seriam insatisfatórias. A primeira alternativa seria o teórico decidir por ele mesmo o que seria bom para a sociedade e, a partir desta decisão, elogiar ou condenar o objeto de seu estudo ${ }^{90}$. Hicks rejeita esta solução, dado sua falta de cientificidade ${ }^{91}$. O segundo método se fundamentaria em uma tentativa de agregar os valores dos termômetros, o que Hicks rejeita por entender que não há como se agregar os valores sem se adotar um sistema de "pesos" para cada um dos valores, sendo que não haveria uma razão conhecida para justificar a escolha por um

\footnotetext{
${ }^{85}$ KALDOR, Nicholas. Welfare propositions of economics and interpersonal comparisons of utility, in: The Economic Journal, Vol. 49, N 195, setembro de 1939, p. 551.

86 'In the second part, concerning distribution, the economist should not be concerned with 'prescriptions' at all, but with the relative advantages of different ways of carrying out certain political ends. For it is quite impossible to decide on economic grounds what particular pattern of income-distribution maximises social welfare. [...]All that economics can, and should, do in this field, is to show, given the pattern of incomedistribution desired, which is the most convenient way of bringing it about." (KALDOR, Nicholas. Welfare propositions of economics and interpersonal comparisons of utility, in: The Economic Journal, Vol. 49, $\mathrm{N}^{\circ}$ 195, setembro de 1939, pp. 551-552).

87 HICKS, J. R. The foundations of welfare economics, in: The Economic Journal, Vol. 49, $\mathrm{N}^{\circ} 196$, dezembro de 1939, p. 698.

${ }^{88}$ HICKS, J. R. The foundations of welfare economics, in: The Economic Journal, Vol. 49, № 196 , dezembro de 1939, p. 697.

89 HICKS, J. R. The foundations of welfare economics, in: The Economic Journal, Vol. 49, № 196 , dezembro de 1939, p. 699.

90 HICKS, J. R. The foundations of welfare economics, in: The Economic Journal, Vol. 49, № 196, dezembro de 1939, p. 699.

91 "This is the method which is rightly condemned as unscientific. It is the way of the prophet and the social reformer, not of the economist" (HICKS, J. R. The foundations of welfare economics, in: The Economic Journal, Vol. 49, $\mathrm{N}^{\circ}$ 196, dezembro de 1939, pp. 699-700).
} 
determinado sistema de "pesos" proposto por Kaldor, que poderia oferecer uma base para a teoria econômica ${ }^{93}$.

Assim, Hicks partindo deste método, passa a analisar criticamente a teoria de Pareto. Em algumas situações, seria possível que um indivíduo percebesse uma melhoria em sua situação, sem que esta melhoria impusesse alguma perda a outro indivíduo, o que representaria um aumento de eficiência do sistema ${ }^{94}$. $\mathrm{O}$ arranjo em que ninguém mais poderia alcançar uma melhora em sua satisfação de necessidades, sem que outro incorrese em uma perda da sua própria capacidade de satisfação, poderia ser definido como o estado ótimo, mas este definição não deixaria de apresentar ambigüidade, pois este grau de otimização poderia se dar de acordo com diferentes arranjos, que dependeriam de diferentes graus de distribuição, que por sua vez se relacionariam com as condições iniciais $^{95}$. Independemente disso, a definição do ótimo importaria que a eficiência no sistema poderia ser aumentada, de modo que ao menos alguns indivíduos poderiam ter suas satisfações melhor atendidas, sem que outros tivessem que fazer alguma espécie de sacrifício $^{96}$.

Adiante, Hicks reconhece que num sistema de economia de mercado, uma alteração da política econômica implicaria em uma mudança no sistema de preços, o que por si só traria benefícios a alguns indivíduos e prejuízos a outros ${ }^{97}$. Entretanto, isto não impediria a aplicação do critério proposto, pois Hicks, como Kaldor, entende que uma

92 HICKS, J. R. The foundations of welfare economics, in: The Economic Journal, Vol. 49, ํㅜ 196 , dezembro de 1939, p. 700.

93 "The third method is Mr. Kaldor's. It consists in concentrating attention upon those cases which have been admitted, even by some of the positivists, to be an exception to their general rule that the impossibility of inter-personal comparisons prevents any estimation of the general efficiency of the economic system. Mr. Kaldor's contribution is to have shown that these cases are not the mere trifling exception they appear to be at first sight, but that they do actually offer a sufficient foundation for at least the more important part of welfare economics" (HICKS, J. R. The foundations of welfare economics, in: The Economic Journal, Vol. 49, $\mathrm{N}^{\circ} 196$, dezembro de 1939, p. 700.).

94 HICKS, J. R. The foundations of welfare economics, in: The Economic Journal, Vol. 49, № 196 , dezembro de 1939, p. 701.

95 "If we start from a given organisation which is not optimum, there will be several different optima which can be reached subject to the condition of no one being damaged, since the 'increment of wealth' can be divided in different ways. In addition to these there will be many other optima which cannot be reached from the initial position, since they involve some people being worse off than they were initially. These are optimum positions all the same, although they could only be reached by a 'permitted reorganisation' if we begin from some other starting-point" (HICKS, J. R. The foundations of welfare economics, in: The Economic Journal, Vol. 49, $\mathrm{N}^{\circ}$ 196, dezembro de 1939, p. 701.).

96 HICKS, J. R. The foundations of welfare economics, in: The Economic Journal, Vol. 49, N ${ }^{\circ} 196$, dezembro de 1939, p. 701.

97 HICKS, J. R. The foundations of welfare economics, in: The Economic Journal, Vol. 49, № 196 , dezembro de 1939, p. 706. 
compensação entre os favorecidos e os prejudicados poderia ser feita e ainda assim "sobrar" um ganho líquido de eficiência, que aproximaria o sistema do ponto ótimo ${ }^{98}$.

Não obstante a utilização da compensação como fator para justificar uma determinada política, que deste modo não prejudicaria indivíduo algum, Hicks entende que não haveria uma necessidade de que a compensação efetivamente fosse posta em prática. Sendo a questão de compensação uma questão de distribuição, em relação à qual haveria diferentes interesses, a economia não poderia propor um princípio geral ${ }^{99}$. Finalmente, ao se efetuar uma distribuição, esta também impactaria negativamente a eficiência produtiva, de modo que esta conseqüência também deveria ser levada em consideração ao se delinear uma determinada política econômica ${ }^{100}$.

Com estes desenvolvimentos de Hicks, a base para a fundamentação da eficiência em seu sentido empregado na teoria econômica atual ${ }^{101}$, bem como as bases da análise econômica do direito, na sua versão da escola de Chicago ${ }^{102}$, estavam lançadas. O entendimento desta teoria passa a ser enfocada, pois, na próxima sessão.

\subsubsection{O processo legislativo e a economia: a visão de Chicago}

Como apontado acima, os teóricos da análise econômica do direito do início do século XX davam particular destaque para a legislação em seus estudos. De maneira diferente, o processo legislativo não é o principal objeto de estudo, segundo a corrente de análise econômica do direito na visão da Escola de Chicago. A razão para tanto se relaciona ao destaque que esta vertente de análise econômica do direito dá ao mercado, pois entende que as transações voluntárias aumentam a eficiência, enquanto as transações

\footnotetext{
98 HICKS, J. R. The foundations of welfare economics, in: The Economic Journal, Vol. 49, № 196 , dezembro de 1939, p. 706.

99 "Whether or not compensation should be given in any particular case is a question of distribution, upon which there cannot be identity of interest, and so there cannot be any generally acceptable principle" (HICKS, J. R. The foundations of welfare economics, in: The Economic Journal, Vol. 49, N $^{\circ}$ 196, dezembro de 1939, p. 711).

${ }^{100}$ HICKS, J. R. The foundations of welfare economics, in: The Economic Journal, Vol. 49, N ${ }^{\circ} 196$, dezembro de 1939, p. 712.

101 "The fact that the conditions for Pareto superiority are almost never satisfied in the real world, yet economists talk quite a bit about efficiency, means that the operating definition of efficiency in economics cannot be Pareto superiority. And in fact when an economist says that free trade or competition or the control of pollution or some other policy or state of the world is efficient, nine times out of ten he means KaldorHicks efficient" (POSNER, Richard A.. Economic analysis of law. 7. ed. Nova Iorque: Aspen, 2007, p. 13).

102 "Common law (i.e., judge-made) rules are often best explained as efforts, whether or not conscious, to bring about either Pareto or Kaldor-Hicks efficient outcomes" (POSNER, Richard A. The law and economics movement, in: The American Economic Review, Vol. 77, $\mathrm{N}^{\circ}$ 2, Papers and proceedings of the ninety-ninth annual meeting of the American Economic Association, maio de 1987, p. 5). Ainda que esta corresponda a só uma parte da "teoria econômica do direito", como assim é proposto (vide abaixo item 3.2).
} 
não voluntárias - isto é as transções forçadas - apresentam um resultado incerto em relação à eficiência. Como a legislação pode conduzir a alterações da situação em que cada indivíduo se encontra, sem que os mesmos tenham que manifestar o seu consentimento - a institucionalização das expectativas normativas promove justamente a antecipação de um consenso, que é deste modo presumido e não expresso -, explica-se deste modo o menor interesse da Escola de Chicago pela legislação do que pela análise das trocas no mercado.

No entender desta corrente teórica, mesmo quando a legislação fosse eficiente - o que ocorreria quando mimetizasse uma troca eficiente -, ela apresentaria uma desvantagem, dado que ela apresentaria custos adicionais à transação que ocorreria no mercado, uma vez que ela envolveria um custo de negociação, que seria inerente ao processo legislativo ${ }^{103}$. Contudo, as transações forçadas não deixam também de ser admitidas pela Escola de Chicago, dado que as transações no mercado também costumam impactar terceiros. Isto é, freqüentemente partes estranhas a um negócio que se desenrola no mercado, sofrem conseqüências - positivas ou negativas - mesmo sem manifestarem o seu consentimento ${ }^{104}$.

Normalmente, o início da concepção que orienta a Escola de Chicago é localizado no princípio da década de 1960, com a publicação de trabalhos de Ronald Coase $^{105}$ e de Guido Calabresi ${ }^{106}$, que passam a explorar uma metodologia - a aplicação de princípios de microeconomia para a abordagem da teoria jurídica - que nos Estados Unidos estava anteriormente restrita ao direito concorrencial ${ }^{107}$. Ainda que tratando de assuntos diferentes, uma linha de raciocínio comum aos dois artigos é a preocupação com uma alocação de recursos eficiente, isto é, com a eficiência alocativa.

Esta eficiência na alocação de recursos se torna, pois, a pedra de toque na análise econômica do direito seguindo a linha proposta pela Escola de Chicago ${ }^{108}$. Segundo esta

\footnotetext{
${ }^{103}$ Para esta questão, vide abaixo item 5.1.

104 "To reconstruct the likely terms of a market transaction in circumstances where instead a forced exchange took place - to mimic or simulate the market, in other words - is difficult. But to ban all forced exchanges would be grossly inefficient. It would amount to abolishing markets, since all market transactions have some uncompensated third-party effects" (POSNER, Richard A.. Economic analysis of law. 7. ed. Nova Iorque: Aspen, 2007, p. 15).

${ }^{105}$ COASE, R. H.. The problem of social cost, in: Journal of Law and Economics, Vol. 3, Outubro de 1960, pp. $1-44$.

${ }^{106}$ CALABRESI, Guido. Thoughts on Risk Distribution and the Law of Torts, in: The Yale Law Journal, Vol. 70, N 4, março de 1961, pp. 499-553.

${ }^{107}$ POSNER, Richard A.. Economic analysis of law. 7. ed. Nova Iorque: Aspen, 2007, p. 23.

108 Deve-se destacar, contudo, que esta não é a única forma de eficiência abordada atualmente. Deve-se destacar também a eficiência dinâmica, que usa a palavra "eficiência" em um sentido menos preciso, mas que se refere ao fato de que a inovação tecnológica deve ser incentivada (KERBER, Wolfgang. Should competition law promote efficiency? - Some reflections of an economist on the normative foundations of
} 
teoria, os princípios que regem o mercado também valem para áreas do direito que tradicionalmente não eram entendidas como sendo econômicas, como afirma Posner:

\begin{abstract}
"People act as rational maximizers of their satisfactions in making such nonmarket decisions as whether to marry or divorce, commit or refrain from committing crimes, make an arrest, litigate or settle a lawsuit, drive a car carefully or carelessly, pollute (a nonmarket activity because pollution is not traded in the market), refuse to associate with people of a different race, fix a mandatory retirement age for employees"
\end{abstract}

Este entendimento de que o comportamento dos indivíduos ao tomar decisões nas áreas vistas como "não econômicas" seria o mesmo das áreas "econômicas"," seria completado, seguindo a linha proposta pela Escola de Chicago, pela percepção de que o direito nestas outras áreas imporia aos indivíduos um preço ou atribuiria determinados incentivos a determinados comportamentos ${ }^{111}$. Estes pressupostos seriam válidos nas duas dimensões da análise econômica, isto é, em sua análise positiva ${ }^{112}$ e sua análise normativa. Enquanto a primeira forma de análise se ocuparia com a explicação do direito como ele é, a segunda buscaria justificar através de uma análise econômica, como o direito poderia apresentar um melhor desempenho ${ }^{113}$.

Mesmo não sendo o centro de sua atenção, a Escola de Chicago também desenvolveu uma análise econômica do processo legislativo. Segundo sua visão, o

competition law, in: DREXL, Josef; IDOT, Laurence; MONÉGER, Joël. Economic theory and competition law. Cheltenham: Elgar, 2009, p. 51).

${ }^{109}$ POSNER, Richard A. The law and economics movement, in: The American Economic Review, Vol. 77, $\mathrm{N}^{\circ}$ 2, Papers and proceedings of the ninety-ninth annual meeting of the American Economic Association, maio de 1987, p. 5.

$110 \mathrm{Na}$ verdade, Posner crítica esta nomenclatura e diferenciação entre áreas "econômicas" e "não econômicas", propondo que as áreas "não econômicas" também seriam econômicas: "about the best one can say is that there is an open-ended set of concepts (such concepts as perfect competition, utility maximization, equilibrium, marginal cost, consumers' surplus, elasticity of demand, and opportunity cost), most of which are derived from a common set of assumptions about individual behavior and can be used to make predictions about social behavior; and that when used in sufficient density these concepts make a work of scholarship 'economic' regardless of its subject matter or its author's degree. When economics is 'defined' in this way, there is nothing that makes the study of marriage and divorce less suitable a priori for economics than the study of the automobile industry or the inflation rate" (POSNER, Richard A. The law and economics movement, in: The American Economic Review, Vol. 77, $\mathrm{N}^{\circ}$ 2, Papers and proceedings of the ninety-ninth annual meeting of the American Economic Association, maio de 1987, p. 2).

${ }^{111}$ POSNER, Richard A. The law and economics movement, in: The American Economic Review, Vol. 77, $\mathrm{N}^{\circ}$ 2, Papers and proceedings of the ninety-ninth annual meeting of the American Economic Association, maio de 1987, p. 5; POSNER, Richard A.. Economic analysis of law. 7. ed. Nova Iorque: Aspen, 2007, p. 555.

112 Também denominada descritiva, Cf. SHAVELL, Steven. Foundations of economic analysis of law. Cambridge: Harvard, 2004, p. 1 e 2.

${ }^{113}$ POSNER, Richard A.. Economic analysis of law. 7. ed. Nova Iorque: Aspen, 2007, pp. 24-25. 
mercado normalmente é o responsável pela alocação de recursos, mas excepcionalmente a alocação de recursos pode apresentar custos menores, caso seja realizada por meio judicial ou através da legislação ${ }^{114}$.

Por fim, entre estes dois métodos, a análise econômica do direito, com raízes na common law, tende a preferir a alocação de recursos por meio de decisões judiciais ${ }^{115}$. O motivo para isso seria a possibilidade de a legislação ser utilizada como forma de favorecimento direcionado a um determinado grupo, que tenha ajudado os legisladores a serem eleitos ${ }^{116}$ ou que promovam lobby em relação a alguma política ${ }^{117}$. De maneira contrária, os juízes não estariam sujeitos a sofrerem uma forma tão intensa de pressão por determinados grupos ${ }^{118}$.

Entretanto, a legislação poderia ser mais adequada em determinadas circunstâncias, como, por exemplo, quando houvesse a necessidade de promover uma alteração rápida e profunda nas regras vigentes ${ }^{119}$. Ademais, em relação a objetivos de distribuição de recursos, a legislação apresentaria um conjunto de instrumentos, que seriam mais adequados do que os oferecidos pelo Judiciário à busca deste fim $^{120}$. Por exemplo, as leis de organização sindical, na visão da Escola de Chicago, entrariam nesta categoria,

${ }^{114}$ POSNER, Richard A.. Economic analysis of law. 7. ed. Nova Iorque: Aspen, 2007, p. 555.

115 "Although the correlation is far from perfect, judge-made rules tend to be efficiency-promoting while those made by legislatures, other than those rules that codify common law principles (for example, much of criminal law and many provisions of the Uniform Commercial Code and other uniform laws) tend to be efficiency-reducing" (POSNER, Richard A.. Economic analysis of law. 7. ed. Nova Iorque: Aspen, 2007, p. 560).

116 "An institutional difference worthy of separate consideration is the greater reliance on the electoral process for the selection of legislators than for the selection of judges. That process creates a market for legislation in which legislators 'sell' legislative protection to those who can help their electoral prospects with money or votes" (POSNER, Richard A.. Economic analysis of law. 7. ed. Nova Iorque: Aspen, 2007, pp. 562-563).

${ }^{17}$ Para um outra visão, defendendo em certa medida o lobby, cf. MACCORMICK, Neil. Rhetoric and the rule of law: a theory of legal reasoning. Nova Iorque: Oxford, 2005, pp. 7-9.

${ }^{118}$ POSNER, Richard A.. Economic analysis of law. 7. ed. Nova Iorque: Aspen, 2007, p. 563.

${ }^{119}$ POSNER, Richard A.. Economic analysis of law. 7. ed. Nova Iorque: Aspen, 2007, p. 562.

120 "Above all, the legislative tools for redistributing wealth are much more flexible and powerful than the judicial. Ordinarily, the only way a common law court can redistribute wealth is by means of (in effect) an excise tax of the activity involved in the suit. It is not easy to redistribute wealth by this means. That may be why the modern welfare state did not take off before income taxation was introduced (of course the causality could go in the opposite direction). With an income tax in place, redistribution is more efficiently achieved by raising income tax rates than by adopting inefficient legal rules. Although both excise taxes (or legal rules functioning like excise taxes) and incomes taxes impair the efficient allocation of resources, as we know and let's assume they impair it by the same amount - the deadweight cost of an inefficient legal rule is likely to exceed the deadweight cost of the slight increase in income tax rates that would be necessary to achieve the same amount of redistribution as the legal rule" (POSNER, Richard A.. Economic analysis of law. 7. ed. Nova Iorque: Aspen, 2007, p. 561). Em relação aos efeitos da tributação, conferir também Cooter e Ulen: "Economists disagree among themselvers abou redistributive ends or goals. However, economists generally agree about redistributive means. Many economists believe that redistributive goals can be accomplished better in modern states by progressive taxation than by reshuffling property rights" (COOTER, Robert; ULEN, Thomas. Law and economics. 2. ed. Reading: Addison-Wesley, 1997, pp. 104-105[grifo no original]). 
dado que seu objetivo não seria a maximização da economia, mas sim o aumento dos salários dos trabalhadores, o que seria complementado pela legislação de proteção trabalhista, como a instituição de um salário mínimo ${ }^{121}$.

Não obstante o reconhecimento deste papel da legislação pela Escola de Chicago, como já mencionado, o maior enfoque desta teoria é a aplicação do direito. Esta seção da mencionada teoria passa, pois, a ser analisada a seguir.

\subsection{A aplicação do direito e a análise econômica}

Se a chamada "teoria da eficiência da common law" não se confunde com a "teoria econômica do direito", mas deve ser compreendida como sendo apenas uma parte dela, como defendido por Posner ${ }^{122}$, deve-se considerar que esta parte ocupa significativa proporção daquela teoria que é tomada como o todo ${ }^{123}$. Uma explicação para esta posição de destaque desta parte da teoria seria a concepção de que o direito criado pelos magistrados seria mais eficiente do que o criado pelos legisladores, como freqüentemente a análise econômica do direito defende ${ }^{124}$.

Como argumento desta concepção, como já acima exposto ${ }^{125}$, Posner expõe a menor propensão dos magistrados a pensarem nas preferências individuais dos litigantes, de modo que os juízes poderiam decidir de uma maneira tendente a promover a alocação de recursos, isto é, como haveria uma neutralização política do Judiciário, os integrantes

${ }^{121}$ POSNER, Richard A.. Economic analysis of law. 7. ed. Nova Iorque: Aspen, 2007, p. 352.

122 "The 'economic theory of law' and the 'efficiency theory of the common law' should not be confused. The former tries to explain as many legal phenomena as possible though the use of economics. The latter (which is included in the former) hypothesizes a specific economic goal, that of economic efficiency in the Kaldor-Hicks sense, for a limited subset of legal rules, institutions and so forth" (POSNER, Richard A.. Economic analysis of law. 7. ed. Nova Iorque: Aspen, 2007, p. 26)

${ }^{123}$ Um possível motivo para tanto, poderia ser a origem da Escola de Chicago em um sitema de Common Law, em que o papel do juiz predomina. Talvez isso explique uma maior atenção para a atividade judicial, como se pode perceber no seguinte trecho, em que o papel do juiz é destacado com naturalidade: "In adition to a scientific theory of behavior, economics provides a useful normative standard for evaluating law and policy. Laws are not just arcane technical arguments; they are instruments for achieving important social goals. In order to know the effects of laws on those goals, judges and others lawmakers must have a method of evaluating law's effects on important social values" (COOTER, Robert; ULEN, Thomas. Law and economics. 2. ed. Reading: Addison-Wesley, 1997, p. 3 [nosso grifo]).

${ }^{124}$ Um possível motivo para tanto, poderia ser a origem da Escola de Chicago em um sitema de Common Law, em que o papel do juiz predomina. Talvez isso explique uma maior atenção para a atividade judicial, como se pode perceber no seguinte trecho, em que o papel do juiz é destacado com naturalidade: "In adition to a scientific theory of behavior, economics provides a useful normative standard for evaluating law and policy. Laws are not just arcane technical arguments; they are instruments for achieving important social goals. In order to know the effects of laws on those goals, judges and others lawmakers must have a method of evaluating law's effects on important social values" (COOTER, Robert; ULEN, Thomas. Law and economics. 2. ed. Reading: Addison-Wesley, 1997, p. 3 [nosso grifo]).

${ }^{125}$ Veja item 3.1.2 acima. 
deste estariam menos propensos a decidir de acordo com as preferências individuais, buscando uma decisão que fosse a melhor para a sociedade como um todo. De maneira contrária, os legisladores seriam propensos a atender os interesses individuais daqueles que os elegeram, o que acabaria por comprometer a maximização de eficiência por meio da legislação.

Para além deste argumento, há outra justificativa que os seguidores desta corrente de análise econômica do direito admitem. Trata-se de uma espécie de "darwinismo legislativo", que defende que quando regras ineficientes são instituídas por meio do precedente, elas tendem a serem abandonadas, ao passo que as regras eficientes tendem a ser mantidas ${ }^{126}$. A questão essencial por meio do qual esta evolução legislativa se faria presente seria o interesse que os precedentes despertam, desde que as partes envolvidas em um caso se mostrassem interessadas na regra a respeito do litígio, principalmente em relação ao futuro ${ }^{127}$. Esta condição ficaria atendida quando houvesse organizações que se vêem envolvidas na mesma espécie de casos por diversas vezes, como o governo, sindicatos, ou algumas espécies de empresas - um exemplo para esta categoria seriam as seguradoras $^{128}$. Estas partes teriam interesse na definição do precedente para além do caso que o estabeleceria, dado que uma regra ineficiente imporia custos para o futuro ${ }^{129}$. Para evitar que somente os interesses de uma parte fossem considerados, de modo que a regra estabelecida tenderia a se tornar ineficiente, o sistema judicial preveria diversos mecanismos, como, por exemplo, as ações coletivas ${ }^{130}$.

Este argumento, de que o interesse das partes seria o responsável por promover a eficiência das regras definidas pelos magistrados no sistema da common law, vem a ser posteriormente criticado. Tullock afirma que o mecanismo por traz desta justificativa da eficiência da regra criada pelos magistrados também deveria funcionar para a legislação ou

\footnotetext{
126 "The efficiency of the common law, to the extent that it exists, can be explained by an evolutionary model--a model in which it is more likely that parties will litigate inefficient rules than efficient rules. If decisions are made randomly, there will be a movement in the direction of efficient laws" (RUBIN, Paul H.. Why Is the Common Law Efficient?, in: The Journal of Legal Studies, Vol. 6, N 1, janeiro de 1977, p. 61). 127 "If both parties to a certain type of legal dispute have a substantial interest in future cases of this sort, then precedents will evolve towards efficiency, the common law situation posited by Posner. If rules are inefficient, there will be an incentive for the party held liable to force litigation; if rules are efficient, there will be no such incentive. Thus, efficient rules will be maintained, and inefficient rules litigated until overturned" (RUBIN, Paul H.. Why Is the Common Law Efficient?, in: The Journal of Legal Studies, Vol. 6, $\mathrm{N}^{\circ} 1$, janeiro de 1977, p. 53).

${ }^{128}$ RUBIN, Paul H.. Why Is the Common Law Efficient?, in: The Journal of Legal Studies, Vol. 6, $\mathrm{N}^{\circ} 1$, janeiro de 1977, p. 53.

${ }^{129}$ PRIEST, George L.. The Common Law Process and the Selection of Efficient Rules, in: The Journal of Legal Studies, Vol. 6, № 1, janeiro de 1977, p. 65.

${ }^{130}$ PRIEST, George L.. The Common Law Process and the Selection of Efficient Rules, in: The Journal of Legal Studies, Vol. 6, N 1, janeiro de 1977, p. 75
} 
por regras estabelecidas pelo poder executivo, uma vez que o lobby nestes setores tenderia a promover ao menos os mesmos resultados que os esforços de litigância contínua de uma mesma regra $^{131}$.

Esta crítica chega a ser considerada pelos defensores da eficiência da common $l a w^{132}$, que, apesar de levarem em consideração o argumento, acabam por manter uma defesa de ao menos haver a aparência de que há maior eficiência por parte das regras definidas pelos magistrados em relação às estabelecidas pela legislação ${ }^{133}$. Desse modo a análise econômica do direito como defendida pela Escola de Chicago continua considerando que a common law apresenta maior eficiência do que a determinação de normas a partir da legislação ${ }^{134}$.

\subsection{Análise econômica do direito no direito concorrencial}

Como visto, a Escola de Chicago propõe uma análise econômica do direito para todos os campos jurídicos, incluindo os campos do direito entendidos tradicionalmente como não sendo pautados por princípios econômicos, como o direito de família ou o direito penal. Apesar disso, não há dúvida que o campo em que esta teoria alcança maior repercussão é o campo do direito concorrencial ${ }^{135}$.

O direito concorrencial, antes mesmo da difusão do movimento da Escola de Chicago, já era um campo do direito marcado por uma análise econômica ${ }^{136}$. Nos Estados Unidos, berço da análise concorrencial contemporânea, bem como nos outros países em

\footnotetext{
131 "The lobbyists who approach congressmen or government regulators are only interested in the future, and general, impact of whatever change they are urging; and, hence, the efficiency considerations should play a much larger part in decision making at this level than in judicial decision making" (TULLOCK, Gordon. Trials on trial: the pure theory of legal procedure. Nova Iorque: Columbia, 1980, p. 198).

${ }^{132}$ RUBIN, Paul H.. Common law and statute law, in: The Journal of Legal Studies, Vol. 11, N ${ }^{\circ} 2$, junho de 1982, p. 207.

133 "It does appear that common law is preferable to statute, but this appearance is more a function of the time at which each type of rule dominated the legal system" (RUBIN, Paul H.. Common law and statute law, in: The Journal of Legal Studies, Vol. 11, N², junho de 1982, p. 222).

${ }^{134}$ HOVENKAMP, Herbert. The first great law \& economics movement, in: Stanford Law Review, Vol. 42, $\mathrm{N}^{\circ}$ 4, abril de 1990, p. 1015.

135 "The law and economics movement has affected most branches of law in the United States. But antitrust differs from other legal topics because the subjects with which antitrust deals have always been central to the social science of microeconomics" (SULLIVAN, Lawrence A.; GRIMES, Warren S.. The law of antitrust: an integrated handbook. 2. ed. St. Paul: Thomson West, 2006, p. 19). Neste sentido, a Escola de Chicago predominou na concepção do direito concorrencial, ainda que ela seja crítica pelo pensamento "pós-Chicago" ou encontre divergências no método europeu. Para uma introdução nas diferentes escolas, cf. SALOMÃ̃ FILHO, Calixto. Direito concorrencial - as estuturas. São Paulo: Malheiros, 1998, p. 18 e ss; EMMERICH, Volker. Kartellrecht. 11. ed. Munique: Beck, 2008, .p. 4 e ss.

${ }^{136}$ POSNER, Richard A.. Economic analysis of law. 7. ed. Nova Iorque: Aspen, 2007, p. 23.
} 
que a economia se orienta pelo mercado, este é o núcleo do direito concorrencial ${ }^{137}$. No entanto, o direito concorrencial surge justamente como uma forma de lidar com as chamadas imperfeições do mercado:

"Of the more than 90 nations that have now adopted competition laws, each has to a considerable extent embraced the market as the optimal allocator of productive resources and distributor of the goods and services these resources produce. Although competition laws differ widely in coverage, methods of enforcement, and effectiveness of enforcement, these laws have one clear element in common. Each responds to oppressive use of economic power. When market actors accumulate power, that power can distort allocation and be exercised in a manner society deems oppressive" ${ }^{\text {"138. }}$.

Deste modo, o direito concorrencial assume o mercado como parâmetro, mas também controla os efeitos que podem decorrer do mesmo, quando há concentração de poder econômico, o que poderia impedir que o mercado funcionasse da maneira entendida como adequada ${ }^{139}$. Deve-se destacar, contudo, que especificamente nos Estados Unidos, por meio de uma aplicação extremada das teorias da Escola de Chicago, há uma defesa do pressuposto da eficiência, como uma manifestação a favor da liberdade no mercado, o que acaba por diminuir significativamente, as possíveis intervenções no mercado, que o direito concorrencial poderia justificar $^{140}$.

Feita esta observação, é de se destacar, que este ramo do direito persegue determinados objetivos ligados à proteção ou ao favorecimento da situação do consumidor $^{141}$, seja impedindo a transferência de riquezas que ocorreriam no cenário de

${ }^{137}$ SULLIVAN, Lawrence A.; GRIMES, Warren S.. The law of antitrust: an integrated handbook. 2. ed. St. Paul: Thomson West, 2006, p. 1.

${ }^{138}$ SULLIVAN, Lawrence A.; GRIMES, Warren S.. The law of antitrust: an integrated handbook. 2. ed. St. Paul: Thomson West, 2006, pp. 1-2.

139 "Antitrust's overriding goal is to maintain public confidence in the market mechanism by deterring and punishing instances of economic opretion" (SULLIVAN, Lawrence A.; GRIMES, Warren S.. The law of antitrust: an integrated handbook. 2. ed. St. Paul: Thomson West, 2006, p. 10).

140 "The heart of Chicago School is not its model for finding a violation. The heart is everything else. Chicagoans state what the law reprehends in terms as narrow as possible. Chicago is not fighting a war against inefficiency. Chicago is fighting a war for private freedom of action. Chicago's critical contention and presumption that firms act efficiently is not a descriptive observation that produces the conclusion that almost everything is legal. It is simply argument supporting the normative claim that people (including firms) should be left free to act and that there is almost never a higher social interest" (FOX, Eleanor M.. Consumer Beware Chicago, in: Michigan Law Review, Vol. 84, № 8, Agosto de 1986, pp. 1715-1716).

${ }^{141}$ Destaque-se que "consumidor" não é entendido no sentido estrito da legislação consumerista, de modo que mesmo entidades que não são se valem de um bem ou serviço como destinatários finais, podem vir a ser entendidos como "consumidores". 
monopólio, seja conservando a possibilidade de escolha pelo consumidor $^{142}$, ou ainda promovendo a inovação e incentivando a eficiência dinâmica ${ }^{143}$.

Tendo em vista o vínculo destas questões com a teoria econômica, explica-se o destacado papel que a análise econômica desempenha neste ramo do direito. Com efeito, há a utilização de diversas ferramentas da microeconomia no direito concorrencial. A título de exemplo, pode-se mencionar a questão da determinação de preços, que pode embasar a apuração de prática de preço predatório, ou mesmo a definição de poder de mercado, que pressupõe a delimitação de um mercado relevante para um produto em uma determinada área - o que se dá por meio da análise da elasticidade cruzada de demanda e oferta - para que depois, com base em outros fatores, como às barreiras à entrada (ou à saída) do mercado, se verifique qual é efetivamente o poder que é exercido pela empresa em questão.

No Brasil o direito concorrencial também se mostra como um campo em que há uma intensa área de interseção entre o direito e a economia. A composição do Sistema Brasileiro de Defesa da Concorrência (SBDC) serve de indício comprobatório dessa afirmação. O SBDC, além de ser composto pelo Conselho Administrativo de Defesa Econômica (CADE), também é composto pela Secretaria de Direito Econômico do Ministério da Justiça (SDE) e pela Secretaria de Acompanhamento Econômico (SEAE), órgão ligado ao Ministério da Fazenda.

A interrelação entre direito e economia, além de se mostrar nos nomes das Secretarias e nos órgãos aos quais elas se submetem (Ministério da Justiça e Ministério da Fazenda), também é perceptível na aplicação da Lei 8.884/1994 ${ }^{144}$ à análise de condutas anticoncorrenciais ou na avaliação de contratos que possam ter efeito anticoncorrencial, em que o poder de mercado aparece como um dos principais critérios. Como marco inicial para esta análise impregnada de elementos econômicos na definição de casos concorrenciais, costuma-se apontar o caso Kolynos/Colgate como um momento em que a análise econômica passou a ganhar força, bem como a ser fundada em maior embasamento teórico $^{145}$.

${ }^{142}$ SULLIVAN, Lawrence A.; GRIMES, Warren S.. The law of antitrust: an integrated handbook. 2. ed. St. Paul: Thomson West, 2006, p. 12 e ss.

${ }^{143}$ HOVENKAMP, Herbert; JANIS, Mark D.; LEMLEY, Mark A. IP and antitrust: an analysis of antitrust principles applied to intellectual property law. Austin: Aspen, 2002, p. 1-9 e ss..

${ }^{144}$ Para uma análise da evolução da legislação concorrencial e de sua aplicação no Brasil, Cf. FORGIONI, Paula A. Os fundamentos do antitruste. 3 ed. São Paulo: RT, 2008, p.104 e ss.

145 "O marco inicial de inserção de uma análise econômica mais sofisticada no CADE, que foi o caso da compra da Kolynos pela Colgate, no segmento de higiene bucal, relatado pela então conselheira Lúcia Salgado, e julgado pelo Conselho em 1996. Tendo trabalhado nesse caso como assessor, pude testemunhar, sem me dar conta da transformação que ora se procedia no paradigma de análise antitruste no Brasil, a perplexidade de parte do meio jurídico atuante na área com a complexidade e profundidade da análise 
Além disso, a própria composição do CADE é um indicativo da interação entre direito e economia. De acordo com o caput do Art. 4 da Lei 8.884/1994 ${ }^{146}$, o Conselho pode ser formado por "integrantes de notório saber jurídico ou econômico", de modo que desde $1996^{147}$ normalmente em sua composição convivem economistas e operadores do direito. Deve-se destacar que a atuação do CADE, um órgão administrativo, em muito lembra a atuação desempenhada por um órgão com função jurisdicional ${ }^{148}$, ainda que seus membros não tenham necessariamente formação jurídica ${ }^{149}$.

\subsubsection{A Europa e uma abordagem mais econômica do direito concorrencial}

Como antes mencionado, a Escola de Chicago conseguiu imprimir sua teoria como doutrina dominante do direito concorrencial norte-americano, o que acabou por influenciar outros países. Contudo, a Escola de Chicago historicamente encontrou resistência por parte de determinados países e regiões.

Na União Européia, a aplicação do direito concorrencial historicamente buscava outra base teórica, mais voltada às teorias da Escola de Friburgo, isto é, a teoria do ordoliberalismo $^{150}$. Esta corrente teórica, tendo como principais expoentes o economista

econômica realizada. O que era um adereço subsidiário, que se duvidava pudesse desenhar o formato das decisões nessa área, passava a se tornar essencial no país. A boa teoria econômica vinha para ficar na defesa da concorrência. A 'revolução' apenas se iniciava” (MATTOS, César. Introdução, in: MATTOS, César [Org.]. A revolução do antitruste no Brasil: a teoria econômica aplicada a casos concretos. São Paulo: Singular, 2003, p. 22).

146 "Art. $4^{\circ}$ O Plenário do Cade é composto por um Presidente e seis Conselheiros escolhidos dentre cidadãos com mais de trinta anos de idade, de notório saber jurídico ou econômico e reputação ilibada, nomeados pelo Presidente da República, depois de aprovados pelo Senado Federal".

${ }^{147}$ MATTOS, César. Introdução, in: MATTOS, César (Org.). A revolução do antitruste no Brasil: a teoria econômica aplicada a casos concretos. São Paulo: Singular, 2003, p. 22.

${ }^{148}$ Em análise a respeito de a Autoridade Concorrencial Grega (Epitropi Antagonismou) e sua possibilidade de submeter questões ao Tribunal de Justiça das Comunidades Européias, o que pressuporia uma natureza jurisdicional, o Advogado-Geral Jacobs concluiu que a referida instituição teria "carácter suficientemente judicial para poder ser qualificada como órgão jurisdicional para efeitos do artigo 234. ${ }^{\circ}$ CE" (Conclusões do Advogado-Geral Jacobs de 28 de outubro de 2004, Processo C-53/03, Synetairismos Farmakopoion Aitolias \& Akarnanias [Syfait] e outros contra Glaxosmithkline AEVE, Colectânea de Jurisprudência de 2005, p. I4609 e ss., Parágrafo 32). Contudo, o Tribunal de Justiça das Comunidades Européias não seguiu as conclusões do Advogado-Geral, entendendo que a mencionada instituição "não tem natureza jurisdicional, na acepção do artigo 234. ${ }^{\circ}$ CE" (Acórdão do Tribunal de Justiça das Comunidades Européias de 31 de maio de 2005, Processo C-53/03, Synetairismos Farmakopoion Aitolias \& Akarnanias [Syfait] e outros contra Glaxosmithkline AEVE, Colectânea de Jurisprudência de 2005, p. I-4609 e ss., Parágrafo 37). Deve-se destacar a pertinência desta análise dado que a Autoridade Concorrencial Grega também é composta por economistas e operadores do direito, como o CADE (v. Conclusões do Advogado-Geral Jacobs de 28 de outubro de 2004, Processo C-53/03, Synetairismos Farmakopoion Aitolias \& Akarnanias [Syfait] e outros contra Glaxosmithkline AEVE, Colectânea de Jurisprudência de 2005, p. I-4609 e ss., Parágrafo 23 e ss.), sendo que apenas dois de seus nove membros tem obrigatoriamente formação jurídica.

${ }^{149}$ Para um debate desta questão, vide abaixo item 3.3.1.

150 "The ideas of the so-called 'Freiburg School' were the matrix of a new brand of liberal thought that has much influenced the evolution of social and economic policy in Europe since the war and has played a 
Walter Eucken e os acadêmicos com formação jurídica Franz Böhm e Hans GrossmannDoerth, tem como origem a crítica das condições que levaram a Alemanha do período ente a Primeira e a Segunda Guerras Mundias a promover uma profusão dos cartéis ${ }^{151}$.

Para os ordoliberais, a economia poderia promover a integração da sociedade em torno de valores mais humanos e democráticos, desde que o mercado funcionasse de uma maneira que os membros da sociedade percebessem que fosse justa e que promovesse oportunidades de participação para todos ${ }^{152}$. Neste contexto, o poder econômico deveria ser combatido, pois criaria a impressão de o mercado não ser justo e conseqüentemente não fomentar a integração social ${ }^{153}$. Neste sentido, em vez de seguirem apenas uma economia social (soziale Wirtschaft) como defendido na Alemanha anteriormente por Stammler, como já citado, passam a defender uma economia de mercado social (soziale Marktwirtschaft), isto é uma economia que não fosse governada centralmente ${ }^{154}$.

Com efeito, a concorrência e a política concorrencial passam a desempenhar um papel central para o funcionamento adequado do mercado como promotor de integração social $^{155}$. Nesse sentido, a concorrência era entendida como uma concorrência completa (vollständinger Wettbewerb ou vollständige Konkurrenz), segundo a qual não reinaria o completo laissez-faire, mas na qual haveria uma competição pelos méritos (Leistungswettbewerb) e na qual haveria concorrência tanto na oferta, como na demanda,

central role in the development of competition law" (GERBER. David J. Law and competition in twentieth century Europe: protecting Prometheus. Oxford: Clarendon, 1998, p. 232).

151 "Ordoliberals focused not only on the institutional and political failures of the Weimar and Nazi periods, but on the intellectual failures implicated in them. They saw contemporary economic and legal thought as fundamentally flawed, and a major part of their agenda was to expose those flaws and thereby to avoid them in the future" (GERBER. David J. Law and competition in twentieth century Europe: protecting Prometheus. Oxford: Clarendon, 1998, p. 237).

${ }^{152}$ GERBER. David J. Law and competition in twentieth century Europe: protecting Prometheus. Oxford: Clarendon, 1998, p. 241.

${ }^{153}$ GERBER. David J. Law and competition in twentieth century Europe: protecting Prometheus. Oxford: Clarendon, 1998, p. 241.

${ }^{154}$ Contudo, deve-se observar que para alguns há uma diferença entre a Escola de Friburgo e a defesa da economia de mercado social: "Social market economy supporters agreed on most points of economic policy with the ordoliberals, but they placed greater emphasis on assuring that the benefits of the market be distributed equitably throughout society. From many perspectives, ordoliberal and social market economy doctrine are closely related, and the terms are often used almost interchangeably" (GERBER. David J. Law and competition in twentieth century Europe: protecting Prometheus. Oxford: Clarendon, 1998, p. 237).

155 „Die Wirtschaftspolitik der Wettbewerbsordnung ziel darauf, den Märkten eine solche Ordnung zu geben, daß alle Teile des Wirtschaftsprozesses sinnvoll integriert werden. Der einzelne Landwirt, der Industrielle, der Handwerker und Arbeiter, also der einzelne Betrieb und Haushalt, soll frei planen und handeln. (...) Auch die Arbeiter sind nicht zum Dienst in einer bestimmten Verwendung verpflichtet. Sie haben das Recht der Freizügigkeit und des freien Arbeitsvertrages. Es besteht Konsumfreiheit. Aber es besteht nicht die Freiheit, die Spielregeln oder die Formen, in denen sich der Wirtschaftsprozeß abwickelt, die Marktformen und Geldsysteme nach Willkür zu gestalten. Gerade hier hat die Ordnungspolitik ihr Feld“" (EUCKEN, Walter. Grundsätze der Wirtschaftspolitik. 7. ed. Tübingen: Mohr Siebeck, 2004, pp. 245-246). 
de modo que esta concorrência seria apta a orientar o planejamento das unidades econômicas ${ }^{156}$.

Com esta inspiração ordoliberal ${ }^{157}$, o direito concorrencial europeu passa a considerar a proteção do processo competitivo um elemento essencial. Entretanto, para alguns críticos - cuja maioria era composta por teóricos norte-americanos - desta maneira de aplicação do direito concorrencial europeu, este ramo do direito passaria a não mais promover a proteção da concorrência, mas dos concorrentes ${ }^{158}$. De acordo com a resposta que dão a essa crítica aqueles que defendem a aplicação do direito concorrencial de forma a promover, na visão ordoliberal, a proteção do processo competitivo, esse tipo de ênfase se justificaria como uma forma importante de manter a abertura do mercado, garantindo a possibilidade de entrada de novos concorrentes ${ }^{159}$.

Não obstante, esta crítica referente à proteção aos concorrentes recebeu ressonância parcial na União Européia - com destaque para a Comissão Européia - e o final dos anos 1990 registrou o surgimento de uma tese favorável a uma abordagem mais econômica ("more economic approach") do direito ${ }^{160}$, marcada pela influência da teoria americana $^{161}$. Como principais destaques deste debate ${ }^{162}$, pode-se destacar a elaboração do

156 „Was ist vollständige Konkurrenz? Sie ist eine bestimmte, exakt definierbare Marktform und ist nicht mit dem Laissez-faire zu verwechseln. Sie ist auch etwas ganz anderes als ,Monopolkampf' (...) Vollständige Konkurrenz besteht nicht im Kampf von Mann gegen Mann, sondern vollzieht sich in paralleler Richtung. Sie ist nicht Behinderungs- oder Schädigungswettbewerb, sondern ,Leistungswettbewerb'. (...)

Wenn sowohl Anbieter als auch Nachfrager in Konkurrenz miteinander liegen und wenn sie danach ihre Wirtschaftspläne aufbauen, so ist die Marktform der vollständigen Konkurrenz realisiert. (...)

Die vollständige Konkurrenz dient in der Wettbewerbsordnung nicht nur dazu, die Leistung zu steigern, sondern sie ist die Marktform, deren Preise den Wirtschaftsprozeß lenken“ (EUCKEN, Walter. Grundsätze der Wirtschaftspolitik. 7. ed. Tübingen: Mohr Siebeck, 2004, pp. 247-249).

${ }^{157}$ Para uma exposição do modo - contexto político e acadêmico - pelo qual o pensamento ordoliberal veio a se estabelecer no direito concorrencial europeu, cf. GERBER. David J. Law and competition in twentieth century Europe: protecting Prometheus. Oxford: Clarendon, 1998, p. 261 e ss.

${ }^{158}$ FOX, Eleanor M.. "We protect competition, you protect competitors", in: World Competition, Vol. 26, N 2, 2003, p. 149.

${ }^{159}$ FOX, Eleanor M.. "We protect competition, you protect competitors", in: World Competition, Vol. 26, No 2, 2003, pp. 155-156.

160 "In the late 1990s, the European Commission began to change fundamental components of its competition law. Since them, European competition law has moved toward what is generally described as a "more economic approach. The term is used loosely to refer to increased use of economics in competition law and includes increased reliance on economics science to inform the norms of competition law" (GERBER, David J.. Competition law and the institutional embeddedness of economics, in: DREXL, Josef; IDOT, Laurence; MONÉGER, Joël. Economic theory and competition law. Cheltenham: Elgar, 2009, p. 27).

${ }^{161}$ „Der Diskurs zur Ökonomisierung des Kartellrechts auf europäischer Ebene ist angelsächsisch geprägt, was sich nicht notwendig aus der nationalen Herkunft der Proponenten der Ökonomisierung, sondern eher aus ihrer spezifisch ökonomischen Sozialisierung mit Wurzeln vor allem in den USA ergibt" (DREXL, Josef. Wettbewerbsverfassung, in: BOGDANDY, Armin von; BAST, Jürgen. Europäisches Verfassungsrecht: theorethische und dogmatische Grundzüge. 2. ed. Dordrecht: Springer, 2009, p. 907).

${ }^{162}$ Para uma análise de outras etapas, cf. DREXL, Josef. Wettbewerbsverfassung, in: BOGDANDY, Armin von; BAST, Jürgen. Europäisches Verfassungsrecht: theorethische und dogmatische Grundzüge. 2. ed. Dordrecht: Springer, 2009, p. 921. 
Regulamento $2790 / 1999^{163}$ e do Regulamento $772 / 2004^{164}$, bem como o debate acerca da modernização da aplicação do então Art. 82 do Tratado da Comunidade Européia - atual Art. 102 do Tratado sobre o Funcionamento da União Européia.

O Regulamento 2790/1999, que concede isenção a determinados acordos com possíveis restrições verticais à concorrência ${ }^{165}$, representa o primeiro marco de uma abordagem menos preocupada com a forma e mais atenta aos efeitos gerados pelos contratos. Na aplicação deste diploma, a Comissão, por meio de suas Orientações diploma sem caráter normativo vinculante, mas de grande importância, dado que norteia a atuação da Comissão - já esclarecia este objetivo:

\begin{abstract}
“Ao aplicar as regras comunitárias em matéria de concorrência, a Comissão adoptará uma abordagem económica baseada nos efeitos sobre o mercado; os acordos verticais devem ser analisados no seu contexto jurídico e económico. Contudo, no caso das restrições pelo objecto, tal como indicadas no artigo $4^{\circ}$ do Regulamento de Isenção por Categoria, a Comissão não tem de apreciar os efeitos reais sobre o mercado" 166 .
\end{abstract}

Esta exceção à necessidade de apreciação dos efeitos concretos gerados se refere a determinadas cláusulas que tinham conteúdo que se chocavam frontalmente com o conceito de concorrência proposto, de modo que para elas não seria necessário uma prova dos efeitos. Não obstante esta exceção, o direito concorrencial europeu passava a sinalizar uma orientação clara à análise dos efeitos das práticas a serem submetidos ao escrutínio do direito concorrencial.

Este predomínio da orientação do direito concorrencial pelos efeitos das práticas também se faz presente no segundo marco no processo de "economização" do direito

\footnotetext{
${ }^{163}$ Regulamento (CE) N N $^{\circ} 2790 / 1999$ da Comissão de 22 de Dezembro de 1999 relativo à aplicação do $\mathrm{n}^{\circ} 3$ do artigo $81^{\circ}$ do Tratado CE a determinadas categorias de acordos verticais e práticas concertadas, Jornal Oficial $\mathrm{n}^{\circ} \mathrm{L} 336 / 21$ de 29 de dezembro de 1999.

${ }^{164}$ Regulamento (CE) $N^{\circ} 772 / 2004$ da Comissão de 27 de abril de 2004 relativo à aplicação do $\mathrm{n}^{\circ} 3$ do artigo $8^{\circ}$ do Tratado a categorias de acordos de transferência de tecnologia, Jornal Oficial L123/11 de 27 de abril de 2004.

165 Basicamente, o contrato com um outro agente que atua no mesmo escala do mercado seria um contrato que produziria restrições horizontais (em termo gerais, um acordo entre concorrentes), enquanto que um acordo entre agentes de diferentes escalas seria um contrato que poderia produzir restrições verticais (como por exemplo, o contrato entre o fabricante e o distribuidor).

${ }^{166}$ Comunicação da Comissão - Orientações relativas às restrições verticais, Jornal Oficial n C 291/1, de 13 de outubro de 2000.
} 
concorrencial Europeu ${ }^{167}$. É de se notar que o Regulamento 772/2004, que regula a isenção da aplicação do Art. 101, I do Tratado sobre o Funcionamento da União Européia (antigo Art. 81 do Tratado da Comunidade Européia) a determinados acordos de transferência de tecnologia, promoveu uma reorientação da matéria. De acordo com o diploma anteriormente vigente, o Regulamento $240 / 1996^{168}$, a mencionada isenção se orientava com base principalmente na presença de determinadas cláusulas contratuais, que estariam automaticamente isentas ${ }^{169}$ e na ausência de outras cláusulas, que se presentes, retirariam a isenção atribuída ao contrato ${ }^{170}$. Caso as empresas decidissem pactuar um contrato com cláusulas de conteúdo divergente do explicitado nos Arts. $1^{\circ}$ e $2^{\circ}$ do Regulamento 240/1996, seria necessário que o contrato fosse submetido à análise prévia, o que

167 O termo "economização", de uso freqüente para designar algumas alterações do direito concorrencial europeu , não deixa de ser surpreendente, dado que o direito concorrencial já era um campo orientado por princípios econômicos: „Die Verwendung des Begriffs der Ökonomisierung muss im Bereich des europäischen Wettbewerbsrechts überraschen. Das Wettbewerbs- und Kartellrecht war immer ein Recht, das Telos und Logik zumindest auch aus dem ökonomischen Denken bezogen hat. Die Zusammenarbeit von Juristen und Volkswirten gehört zum Alltag der Kartellämter“ (DREXL, Josef. Die neue Gruppenfreistellungsverordnung über Technologietransfer-Vereinbarungen im Spannungsfeld von Ökonomisierung und Rechtssicherheit, in: Gewerblicher Rechtsschutz und Urheberrecht Internationaler Teil, Vol. 53, N 9, setembro de 2003, p. 717).

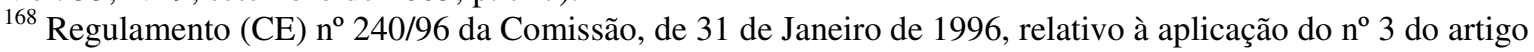
$85^{\circ}$ do Tratado a certas categorias de acordos de transferência de tecnologia, Jornal Oficial $n^{\circ}$ L $31 / 2$ de 9 de fevereiro de 1996.

169 Art. $1^{\circ}$, I do Regulamento 240/96: "Nos termos do no 3 do artigo $85^{\circ}$ [posteriormente renumerado como

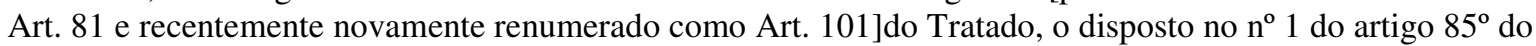
Tratado é declarado inaplicável, nas condições e com as reservas a seguir previstas, aos acordos puros de licença de patente ou de licença de saber-fazer e aos acordos mistos de licença de patente e de saber-fazer, bem como aos acordos que contêm cláusulas acessórias relativas a direitos de propriedade intelectual que não as patentes, em que participem apenas duas empresas e que contenham uma ou mais das seguintes obrigações:

1. A obrigação por parte do licenciante de não a tecnologia licenciada no território objecto de licença;

2. A obrigação por parte do licenciante de não explorar ele próprio a tecnologia licenciada no território objecto da licença;

3. A obrigação por parte do licenciado de não explorar a tecnologia licenciada no território do licenciante no mercado comum;

4. A obrigação por parte do licenciado de não fabricar ou utilizar o produto objecto de licença e de não utilizar o processo objecto de licença nos territórios concedidos a outros licenciados no mercado comum;

5. A obrigação por parte do licenciado de não praticar uma política activa de comercialização do produto objecto de licença nos territórios concedidos a outros licenciados no mercado comum e, especialmente, de não fazer publicidade expressamente destinada a esses territórios, de não estabelecer aí qualquer sucursal nem manter qualquer depósito para a distribuição do produto;

6. A obrigação por parte do licenciado de não comercializar o produto objecto da licença nos territórios concedidos a outros licenciados no mercado comum, em resposta a pedidos de entrega não solicitados;

7. A obrigação por parte do licenciado de apenas utilizar a marca de fábrica do licenciante ou a apresentação determinada por este para distinguir o produto objecto de licença durante o período de validade do acordo, desde que o licenciado não seja impedido de indicar que é o fabricante do produto objecto de licença;

8. A obrigação por parte do licenciado de limitar a sua produção do produto objecto de licença às quantidades necessárias ao fabrico dos seus produtos e de vender o produto objecto de licença unicamente como parte integrante ou como peça sobresselente dos seus produtos, ou enquanto ligado de qualquer outro modo à venda dos seus próprios produtos, desde que tais quantidades sejam livremente determinadas pelo licenciado".

${ }^{170}$ V. Art. $3^{\circ}$ do Regulamento 240/96. 
implicava em uma espera de normalmente quatro meses, até que uma decisão a respeito da conformidade do contrato com o direito concorrencial fosse proferida ${ }^{171}$. Conseqüentemente, o direito anteriormente vigente na Comunidade Européia produzia o chamado efeito de "camisa de força", isto é, as cláusulas listadas no Regulamento acabavam por ser impostas às partes contratantes - mesmo às que não possuíam poder de mercado -, que desse modo não mais podiam determinar livremente - e em consideração às peculiaridades de cada negociação - o conteúdo do contrato a ser estabelecido ${ }^{172}$.

Como forma de alterar esta situação, além de não prever um controle prévio dos contratos, o diploma atualmente em vigor foi introduzido buscando dar uma abordagem mais econômica ao direito concorrencial dos contratos de transferência de tecnologia, de modo que em vez de se pautar tanto na forma - isto é, nas cláusulas contidas no texto do acordo -, passa a se orientar predominantemente nos efeitos gerados no mercado relevante pelo contrato em questão ${ }^{173}$, da mesma maneira que propugnado na análise dos acordos com que promoviam restrições verticais à concorrência. Assim, como critério para se aferir se os contratos de transferência de tecnologia estavam de acordo com o direito concorrencial, aparece com destaque a apuração da quota de participação no mercado (market share) das empresas participantes no mercado relevante a que o contrato se refere.

Fazendo uso desta análise do percentual de participação no mercado, o Regulamento 772/2004, nos termos dos seus artigos $2^{\circ}$ e $3^{\circ}$, determina a isenção aos contratos, desde que as partes contratantes não tenham em conjunto participação superior a $20 \%$ dos mercados relevantes envolvidos, caso sejam concorrentes, ou àquela quota não exceda $30 \%$, para a hipótese de as partes contratantes não serem concorrentes. Ademais o disposto no Regulamento 772/2004 em parte manteve o estabelecido nas disposições

\footnotetext{
${ }^{171}$ DREXL, Josef. Die neue Gruppenfreistellungsverordnung über Technologietransfer-Vereinbarungen im Spannungsfeld von Ökonomisierung und Rechtssicherheit, in: Gewerblicher Rechtsschutz und Urheberrecht Internationaler Teil, Vol. 53, $\mathrm{N}^{\circ}$ 9, setembro de 2003, p. 724.

172 „Diese Regeln galten genauso für Unternehmen ohne Marktmacht. In der Praxis definierten damit die beiden Kataloge zulässiger Klauseln den Inhalt des Verträge und machten andere, ökonomisch sinnvolle Vereinbarungen unmöglich (sog. Zwangsjackeneffekt). Faktisch normierte die Verordnung Nr. 240/96 zwingendes Lizenzkartellrecht“" (DREXL, Josef. Die neue Gruppenfreistellungsverordnung über Technologietransfer-Vereinbarungen im Spannungsfeld von Ökonomisierung und Rechtssicherheit, in: Gewerblicher Rechtsschutz und Urheberrecht Internationaler Teil, Vol. 53, N 9, setembro de 2003, p. 724.). 173 "O presente regulamento deve preencher o duplo requisito de assegurar uma concorrência efectiva e garantir uma segurança jurídica adequada às empresas. A prossecução destes objectivos deve ter em conta a necessidade de simplificar o quadro regulamentar e a sua aplicação. É conveniente renunciar à abordagem que consiste em enumerar as cláusulas isentas e dar maior ênfase à determinação das categorias de acordos isentos até um determinado nível de poder de mercado, bem como à identificação das restrições ou cláusulas que não podem constar desses acordos. Tal coaduna-se com uma abordagem de carácter económico que aprecia o impacto dos acordos no mercado relevante. É igualmente consentâneo com esta abordagem estabelecer uma distinção entre os acordos entre concorrentes e os acordos entre não concorrentes" (Regulamento 772/2004, Considerando $\mathrm{N}^{\circ} 4$ ).
} 
anteriormente vigentes, ao prever que a isenção não será conferida, caso se verifique a presença de determinadas cláusulas nos contratos ${ }^{174}$.

Dentro das inovações trazidas pelo Regulamento 772/2004, um dispositivo que se mostra peculiarmente interessante para o estudo aqui desenvolvido é o Art. 8, II:

\begin{abstract}
"Se a quota de mercado referida nos $n^{\text {os }} 1$ ou 2 do artigo $3^{\circ}$ não for inicialmente superior a $20 \%$ ou $30 \%$, respectivamente, mas vier posteriormente a ultrapassar estes níveis, a isenção prevista no artigo $2^{\circ}$ continuará a ser aplicável durante o período de dois anos civis subsequentes ao ano em que o limiar de $20 \%$ ou $30 \%$ foi excedido pela primeira vez".
\end{abstract}

De acordo com este dispositivo, um contrato que, por ocasião de sua elaboração, esteja de acordo com o direito vigente, pode vir posteriormente a representar uma infração ao direito vigente, sem que o mesmo tenha se alterado. Nesta situação, somente uma alteração da participação do mercado poderia representar uma alteração da qualificação jurídica. Destaque-se que o fato de o contrato não estar mais automaticamente coberto pela isenção não significa que ele representa uma restrição à concorrência, que seja combatida pelo direito concorrencial ${ }^{175}$. Isto é, pode ser que mesmo com alteração da quota de participação no mercado, não haja uma alteração da classificação jurídica. Para que tal situação se configurasse, as disposições contratuais não deveriam representar uma restrição à concorrência, ou caso o fossem, deveriam estar determinadas de modo a serem protegidas por uma isenção da regra geral do Art. 101, III do Tratado sobre o Funcionamento da União Européia (antigo Art. 81, III do Tratado da Comunidade Européia).

Entretanto, caso uma destas hipóteses não esteja prevista, a simples alteração da participação agregada no mercado relevante representará uma alteração da qualificação jurídica de um contrato, que atendia a todos os requisitos de validade estipulados pelo ordenamento jurídico, quando de sua elaboração. Uma solução para evitar que o contrato

\footnotetext{
${ }^{174}$ Entretanto, o conteúdo das cláusulas difere do conteúdo especificado na lista anterior. Cf. Art. $5^{\circ}$ do Regulamento 772/2004.

${ }^{175}$ Destaque-se o Considerando de número 12 do Regulamento 772/2004: "Não se pode presumir que acima destes limiares de quota de mercado os acordos de transferência de tecnologia são abrangidos pelo $n^{\circ} 1$ do artigo $81^{\circ}$ Por exemplo, um acordo exclusivo de concessão de licenças entre empresas não concorrentes muitas vezes não é abrangido pelo $n^{\circ} 1$ do artigo $81^{\circ}$ Também não se pode presumir que, acima destes limiares de quota de mercado, os acordos de transferência de tecnologia abrangidos pelo $\mathrm{n}^{\circ} 1$ do artigo $81^{\circ}$ não satisfazem as condições de isenção. Da mesma forma, também não se pode presumir que conduzem normalmente a benefícios objectivos que pela sua natureza e dimensão compensam as desvantagens provocadas do ponto de vista da concorrência".
} 
seja futuramente declarado como nulo, as partes poderiam se valer do prazo de dois anos para renegociar o contrato.

Após a apresentação destes marcos da "economização" do direito concorrencial europeu, convém passar a análise ao marco seguinte, isto é, o debate acerca da modernização da verificação do abuso de posição dominante. Este debate se originou a partir de proposta da Comissão Européia, que em dezembro de 2005 propôs uma reavaliação da aplicação do então Art. 82 do Tratado da Comunidade Européia para abusos de posição dominante que provocavam a exclusão ${ }^{176}$ - observando-se que o âmbito de aplicação do mencionado artigo incluía práticas não necessariamente exclusionárias, como, por exemplo, a cobrança de preços não equitativos ${ }^{177}$.

Como no Regulamento 2790/1999 e no Regulamento 772/2004, um tópico importante se referia à abordagem enfocada nos efeitos e não mais na forma das condutas e atos a serem analisados pelo direito concorrencial. Este era inclusive o limitador da fronteira entre as práticas cobertas na nova orientação, que deveriam manifestar um efeito exclusionário $^{178}$. Contudo, se o debate a respeito da modernização da aplicação do Art. 82 do Tratado da Comunidade Européia (atual Art. 102 do Tratado sobre o Funcionamento da União Européia) apresentou um caráter de continuidade no debate, também apresentou um caráter de inovação, dado que nele houve grande polêmica a respeito de quais efeitos, que deveriam ser considerados na aplicação do mencionado dispositivo.

De acordo com uma proposta teórica, que ganhou força entre parte dos participantes - principalmente os economistas -, refere-se a uma aproximação entre os critérios do abuso de posição dominante no direito europeu e os critérios para aplicação da figura da Monopolization do direito americano ${ }^{179}$. Dentro desta proposta, o principal ponto debatido seria a indispensabilidade de se demonstrar o prejuízo ao consumidor, como

\footnotetext{
${ }^{176}$ DG Competition discussion paper on the application of Article 82 of the Treaty to exclusionary abuses, 2005, disponível em: http://ec.europa.eu/competition/antitrust/art82/discpaper2005.pdf (último acesso em 14 de dezembro de 2009).

177 Atual Art. 102, lit. a do Tratado sobre o funcionamento da União Européia.

178 "This discussion paper sets out possible principles for the Commission's application of Article 82 of the Treaty to exclusionary abuses. By exclusionary abuses are meant behaviours by dominant firms which are likely to have a foreclosure effect on the market, i.e. which are likely to completely or partially deny profitable expansion in or access to a market to actual or potential competitors and which ultimately harm consumers" (DG Competition discussion paper on the application of Article 82 of the Treaty to exclusionary abuses, 2005, disponível em: http://ec.europa.eu/competition/antitrust/art82/discpaper2005.pdf [último acesso em 14 de dezembro de 2009])

179 DREXL, Josef. Wettbewerbsverfassung, in: BOGDANDY, Armin von; BAST, Jürgen. Europäisches Verfassungsrecht: theorethische und dogmatische Grundzüge. 2. ed. Dordrecht: Springer, 2009, p. 921.
} 
critério para a aplicação do Art. 102 do Tratado sobre o Funcionamento da União Européia $^{180}$.

Entretanto, esta proposta foi alvo de restrições, principalmente por parte daqueles com uma formação jurídica, que propugnavam que a aplicação do abuso de posição dominante não poderia ser dificultada, com a inclusão do critério da indispensabilidade de comprovação de prejuízo ao consumidor ${ }^{181}$. Para estes, dois pontos sofreriam grandes abalos por meio desta economização do direito concorrencial europeu: primeiramente, os critérios propostos seriam de difícil aplicação na prática, de modo que não poderiam atender à necessidade de segurança jurídica ${ }^{182} \mathrm{e}$, além disso, um segundo ponto se referiria à impossibilidade de o direito concorrencial europeu abandonar suas raízes, isto é uma base do pensamento ordoliberal ${ }^{183}$.

\footnotetext{
180 "An economic approach to Article 82 focuses on improved consumer welfare. In so doing, avoids confusing the protection of competition with the protection of competitors and it stresses that the ultimate yardstick of competition policy is in the satisfaction of consumer needs. Competition is a process that forces firms to be responsive to consumers needs with respect to price, quality, variety, etc.; over time it also acts as a selection mechanism, with more efficient firms replacing less efficient ones. Competition is therefore a key element in the promotion of a faster growing, consumer-oriented and more competitive European economy" (REY, Patrick et alii. Report by the EAGCP : "An economic approach to Article 82", 2005, disponível em http://ec.europa.eu/competition/publications/studies/eagcp_july_21_05.pdf [último acesso em 15 de dezembro de 2009]).

${ }^{181}$ EILMANBERGER, Thomas. Verbraucherwohlfahrt, Effizienzen und ökonomische Analyse - neue Paradigmen im europäischen Kartellrecht?, in: Zeitschrift für Wettbewerbsrecht (ZWeR), Vol. 4, N4, 2009, p. 456.

${ }_{182}$ „Worin liegt nach alledem die Zukunft der Missbrauchsaufsicht in einem ökonomisierten Kartellrecht? Aus rechtlicher Sicht muss ein reiner effects based-Ansatz als Grundlage der Kartellrechtsanwendung ausscheiden. Er würde in vieler Hinsicht die Effizienz der administrativen und gerichtlichen Verfahren sowie die für die Rechtsunterworfenen notwendige Rechtssicherheit in Frage stellen. Weiter zeigt sich aber auch, dass das Verhältnis von Recht und Ökonomie bei der Kartellrechtsanwendung keine Einbahnstraße ist. Beide Gebiete sind symbiotisch aufeinander ausgerichtet. So wie einerseits das Recht der Ökonomisierung des Kartellrechts Grenzen setzen muss, sollten andererseits etablierte ökonomische Erkenntnisse in die Kartellrechtsanwendung einfließen können. Um den rechtlichen Gegebenheiten gerecht zu werden, ist dabei vor allem eine Komplexitätsreduzierung erforderlich“ (DREHER, Meinrad. Die Zukunft der Missbrauchsaufsicht in einem ökonomisierten Kartellrecht, in: Wirtschaft und Wettbewerb [WuW], Vol. 58, $\mathrm{N}^{\circ} 1$, janeiro de 2008, p. 27).

${ }^{183}$ „Maßgeblich sind danach die Schutzzwecke der gemeinschaftsrechtlichen Wettbewerbsordnung auf der Basis eines Schutzes unverfälschten Wettbewerbs (Art. 3 lit. g EG) sowie die Verpflichtung zu den Grundsätzen einer offenen Marktwirtschaft mit freiem Wettbewerb (Art. 4 Abs. 1 EG). Diese normierten Schutzzwecke sind im Zusammenhang mit der Verwirklichung des Binnenmarktes sowie den Verkehrsfreiheiten zu sehen. Damit besteht die Aufgabe der Wettbewerbsregeln in der Gewährsleistung eines freien, redlichen, unverfälschten und gleichzeitig wirksamen Wettbewerbs. Die Freiheit des Wettbewerbs wird als unerlässliche Voraussetzung für die Verwirklichung dieser Ziele angesehen. Diesen nicht nur wirtschaftsbezogen Inhalten kann eine Rechtsauslegung nicht entsprechen, die auf ökonomischen Ansätzen beruht und nicht auf die Tatbestände der Normen gegen Wettbewerbsbeschränkungen bezogen ist" (IMMENGA, Ulrich. Ökonomie und Recht in der europäischen Wettbewerbspolitik, in: Zeitschrift für Wettbewerbsrecht (ZWeR), Vol. 4, $\mathrm{N}^{\circ} 4,2006$, p. 365).
} 
Após longo debate, que contou com diversas contribuições ${ }^{184}$, finalmente ao término de 2008 - sendo a versão oficial adotada em todas as línguas comunitárias em fevereiro de 2009 -, a Comissão Européia publicou a versão final do documento, em que expõe suas prioridades na aplicação do dispositivo que regula o abuso de posição dominante ${ }^{185}$. Neste documento, a Comissão Européia aceita que o prejuízo ao consumidor seja um critério para a aferição de um abuso de posição dominante ${ }^{186}$. Contudo, tal critério não é indispensável, podendo o abuso de posição dominante estar configurado, sem que se comprove o prejuízo ao consumidor ${ }^{187}$. Deste modo, pode-se afirmar que o direito concorrencial europeu continua seguindo, ao menos em parte, os princípios colocados pela teoria ordoliberal.

184 Vide os mais de 100 comentários submetidos à Comissão Européia, que podem ser acessados em: http://ec.europa.eu/competition/antitrust/art82/contributions.html (último acesso em 15 de dezembro de 2009).

${ }^{185}$ Orientação sobre as prioridades da Comissão na aplicação do artigo 82. ${ }^{\circ}$ do Tratado CE a comportamentos de exclusão abusivos por parte de empresas em posição dominante, 2009, disponível em: http://ec.europa.eu/competition/antitrust/art82/guidance_pt.pdf (último acesso em 15 de dezembro de 2009).

186 "Na aplicação do artigo $82^{\circ}$ ao comportamento de exclusão por parte de empresas em posição dominante, a Comissão irá privilegiar os tipos de conduta mais prejudiciais para os consumidores. Os benefícios que a concorrência proporciona aos consumidores são preços mais baixos, melhor qualidade e maior variedade de bens e serviços novos ou melhorados. Assim, a Comissão pretende orientar a aplicação da lei no sentido de assegurar o bom funcionamento dos mercados e o benefício por parte dos consumidores da eficiência e produtividade resultantes de uma concorrência efectiva entre as empresas" (Orientação sobre as prioridades da Comissão na aplicação do artigo 82. ${ }^{\circ}$ do Tratado CE a comportamentos de exclusão abusivos por parte de empresas em posição dominante, 2009, disponível em: http://ec.europa.eu/competition/antitrust/art82/guidance_pt.pdf [último acesso em 15 de dezembro de 2009]). 187 “A intervenção da Comissão no âmbito dos comportamentos de exclusão tem sobretudo em vista a salvaguarda da concorrência no mercado interno e a garantia de que as empresas que detêm uma posição dominante não excluirão os seus rivais através de outros meios que não sejam a concorrência com base no mérito dos bens ou serviços que fornecem. Neste contexto, a Comissão reconhece que o mais importante é a protecção de um verdadeiro processo de concorrência e não a mera protecção dos concorrentes" (Orientação sobre as prioridades da Comissão na aplicação do artigo 82. ' do Tratado CE a comportamentos de exclusão abusivos por parte de empresas em posição dominante, 2009, disponível em: http://ec.europa.eu/competition/antitrust/art82/guidance_pt.pdf [último acesso em 15 de dezembro de 2009]). 


\section{TEORIA RETÓRICA DO DIREITO E LIMITES DA APLICAÇÃO JURÍDICA}

O debate a respeito de uma "abordagem mais econômica" para o direito concorrencial europeu, como desenvolvido no capítulo anterior, conduz o presente estudo para a análise de outra questão, isto é, a que se propõe a respeito dos limites e possibilidades da aplicação do direito. Os limites desta aplicação se confundem com os limites da norma ${ }^{188}$, de forma que é essencial que se passe a analisar quais são os limites que uma norma apresenta.

Deve-se destacar inicialmente que a norma não se confunde com o texto normativo. Isto é, a norma decorre de um processo interpretativo que assume o direito como um fenômeno comunicativo e, no caso da legislação, decorre da interpretação que pode ser efetuada a partir do texto normativo. Conseqüentemente, o presente estudo passa a se ocupar da hermenêutica jurídica.

\subsection{O direito como um fenômeno comunicativo}

Para a dogmática jurídica, um conceito de central importância é a norma jurídica $^{189}$. Tal conceito pode ser encontrado em uma diversidade de teóricos, mesmo entre aqueles que apresentam teorias com elevados grau de diferença, como a teoria de Kelsen ${ }^{190}$ ou a teoria de Dworkin ${ }^{191}$, que apresentam diferentes visões da ordem jurídica e da norma

\footnotetext{
188 "From a legal point of view, it has to be pointed out that economic analysis in the application of Art. 82 EC cannot be carried out without limitations. It has to be borne in mind that, after all, the application of Art. $82 \mathrm{EC}$ is the execution of a legal norm. The limits of this norm constitute at the same time the limits of its application" (DREHER; Meinrad; ADAM, Michael. The more economic approach to Art. 82 EC and the legal process, in: Zeitschrift für Wettbewerbsrecht (ZWeR), Vol. 4, N 3, 2006, p. 264).

${ }^{189}$ FERRAZ JR., Tercio Sampaio. Introdução ao estudo do direito: técnica, decisão, dominação. 3. ed. São Paulo: Atlas, 2001, p. 97.

190 "O conhecimento jurídico dirige-se a estas normas que possuem o caráter de normas jurídicas e conferem a determinados fatos o caráter de atos jurídicos (ou antijurídicos). Na verdade, o Direito, que constitui o objeto deste conhecimento, é uma ordem normativa da conduta humana, ou seja, um sistema de normas que regulam o comportamento humano" (KELSEN, Hans. Teoria pura do direito. São Paulo: Martins Fontes, 2000, p. 5).

${ }^{191}$ Este é o ponto de partida de Dworkin: "we live in and by the law. It makes us what we are: citizens and employees and doctors and spouses and people who own things" (DWORKIN, Ronald. Law's empire. Cambridge: Harvard, 1986, p. VII).Mesmo que Dworkin não utilize a expressão "norma", mas "direito" (law), isto pode ser depreendido de uma definição oferecida por Dworkin para o conceito de direito: "I am defending this suggestion about how we might describe our concept of law: for us, legal argument takes place on a plateau of rough consensus that if law exists it provides a justification for the use of collective power against individual citizens or groups" (DWORKIN, Ronald. Law's empire. Cambridge: Harvard, 1986, pp.108-109). Mesmo sua proposta final, (v. DWORKIN, Ronald. Law's empire. Cambridge: Harvard, 1986, p. 410 e ss.) também permite esta leitura.
} 
propriamente dita, mas que nem por isso deixam de destacar a importância da norma para a teoria jurídica.

Certamente o maior grau de diferença entre estas teorias se refere à questão da interpretação e a percepção do direito como um fenômeno comunicativo. Ainda que Kelsen trate da interpretação - e faça importantes observações -, esta não desempenha protagonismo em sua teoria. De maneira contrária, aos poucos, nas últimas décadas, a teoria geral do direito passou a orientar seu debate a partir de questões referentes à hermenêutica.

Não obstante, mesmo não sendo centrais na teoria kelseniana, as observações efetuadas na sua obra Teoria pura do direito tocam pontos extremamente importantes para a hermenêutica. Inicialmente Kelsen diferencia entre a interpretação autêntica e a nãoautêntica ${ }^{192}$. A interpretação autêntica seria aquela que é realizada pelo órgão competente para tanto - e que, de acordo com a teoria kelseniana, teria recebido sua competência através de uma norma superior. A outra definição seria derivada desta, isto é, a interpretação não-autêntica seria definida negativamente, como sendo toda interpretação que não se enquadre na primeira situação. Desse modo, tanto seria uma interpretação nãoautêntica aquela exarada em uma sala de aula por um professor, quanto aquela exposta em um parecer por um promotor, ou aquela realizada por um advogado a orientar seu cliente, ou finalmente a realizada por um cidadão ao promover suas condutas, que supõe, estão de acordo com o previsto pelo direito. Sem ignorar a segunda, Kelsen enfoca sua abordagem na interpretação autêntica.

Segundo aquela relação de validação entre as normas proposta por Kelsen, haveria um grau de concretização ao se passar de um escalão superior de normas (e.g. a Constituição) para um escalão inferior (e.g. Lei). Em outras palavras, uma norma de escalão superior atribuiria uma moldura para uma norma de escalão inferior, podendo esta ocupar qualquer parte da moldura ${ }^{193}$. Neste sentido, haveria um grau de indeterminação na norma a ser interpretada.

Com efeito, na visão de Kelsen, o processo hermenêutico teria duas fases ${ }^{194}$. Em um primeiro momento, haveria um ato de conhecimento, consistindo em delimitar a moldura que comportaria a interpretação. A seguir, haveria um ato de vontade,

${ }^{192}$ KELSEN, Hans. Teoria pura do direito. São Paulo: Martins Fontes, 2000, p. 388.

193 "O Direito a aplicar forma, em todas estas hipóteses, uma moldura dentro da qual existem várias possibilidades de aplicação, pelo que é conforme ao Direito todo ato que se mantenha dentro deste quadro ou moldura, que preencha esta moldura em qualquer sentido possível" (KELSEN, Hans. Teoria pura do direito. São Paulo: Martins Fontes, 2000, p. 390).

${ }^{194}$ KELSEN, Hans. Teoria pura do direito. São Paulo: Martins Fontes, 2000, p. 392 e ss. 
determinando para aquela situação, qual seria o sentido que deveria ser adotado na norma de escalão inferior. À ciência jurídica, pela teoria kelseniana, competiria somente o primeiro momento, pois ao adentrar no momento do ato de vontade e defender uma interpretação como mais correta que outra, a interpretação perderia o caráter científico e tornar-se-ia política ${ }^{195}$.

Dentre os pontos analisados por Kelsen, a diferenciação da interpretação autêntica das outras interpretações, bem como a questão de a interpretação comportar uma moldura que eventualmente não seria respeitada pelo aplicador do direito ${ }^{196}$ - são problemas teóricos que repercutiram no debate posterior referente a um fortalecimento do papel da hermenêutica para a teoria jurídica. Neste processo, outros aspectos da teoria kelseniana passam a ser questionados, como a afirmativa de o papel da teoria jurídica se limitar à delimitação da moldura e a um ato de conhecimento. Podendo a teoria jurídica ir além da mera análise da moldura, a hermenêutica começa a ganhar um papel de destaque para a teoria jurídica.

Para esta colocação da hermenêutica como questão central da teoria geral do direito, uma das obras que tiveram maior contribuição - considerando sua influência no meio jurídico -, para tanto, foi a obra de Hart. Este expôs a chamada "textura aberta do direito", isto é, as regras jurídicas - seja pela forma do precedente, seja pela forma da legislação - são elaboradas por meio da linguagem jurídica, que apresentaria um núcleo em que os significados das palavras seriam claros, sendo que após este núcleo passaria a haver uma zona de incerteza sobre a aplicação do significado ${ }^{197}$.

Para Hart, uma conseqüência dessa textura aberta, seria que parte da definição do direito seria criada pelos aplicadores do direito, dentre os quais se destacariam os

\footnotetext{
195 "Na medida em que, na aplicação da lei, para além da necessária fixação da moldura dentro da qual se tem de manter o ato a pôr, possa ter ainda lugar uma atividade cognoscitiva do órgão aplicador do Direito, não se tratará de um conhecimento do Direito positivo, mas de outras normas, que, aqui, no processo da criação jurídica podem ter a sua incidência: normas de Moral, normas de Justiça (...). Do ponto de vista do Direito positivo, nada se pode dizer sobre a sua validade e verificabilidade. Deste ponto de vista, todas as determinações desta espécie apenas podem ser caracterizadas negativamente: são determinações que não resultam do próprio Direito positivo" (KELSEN, Hans. Teoria pura do direito. São Paulo: Martins Fontes, 2000, p. 393)

196 "Pela via da interpretação autêntica, quer dizer, da interpretação de uma norma pelo órgão jurídico, que a tem de aplicar, não somente se realiza uma mesma norma, como também se pode produzir uma norma que se situe completamente fora da moldura que a norma a aplicar representa" (KELSEN, Hans. Teoria pura do direito. São Paulo: Martins Fontes, 2000, p. 394).

197 "Seja qual for o processo escolhido, precedente ou legislação, para a comunicação de padrões de comportamento, estes, não obstante a facilidade com que actuam sobre a grande massa de casos correntes, revelar-se-ão como indeterminados em certo ponto em que a sua aplicação esteja em questão; possuirão aquilo que foi designado como textura aberta" (HART, Herbert L.A. O conceito de direito. 5.ed. Lisboa: Fundação Calouste Gulbekian, 2007, pp. 140-141 [grifo no original]).
} 
magistrados ${ }^{198}$. Desse modo, a interpretação do direito a ser efetuada pelos que o aplicam, passa a ganhar um papel de notável importância ${ }^{199}$.

Com efeito, o aspecto comunicativo do direito e o estudo da interpretação difundem-se cada vez mais entre os teóricos do direito. Neste sentido, ainda que entre eles haja significantes diferenças teóricas, podem-se destacar diversos autores que promovem o estudo do direito a partir desta perspectiva. Citando apenas alguns nomes, a mero título exemplificativo da difusão dessa abordagem: Herbert L.A. Hart ${ }^{200}$, Ronald Dworkin ${ }^{201}$, Genaro Carrió $^{202}$, Tercio Sampaio Ferraz Jr. ${ }^{203}$, Robert Alexy ${ }^{204}$, Neil MacCormick ${ }^{205}$.

Como uma conseqüência desta concepção do direito como um fenômeno comunicativo, decorre por um lado, que toda norma jurídica depende de um processo interpretativo para ser fixada ${ }^{206}$ e por outro, que o direito também está sujeito às limitações que os fenômenos com este traço característico apresentam. Desse modo, para um bom entendimento do direito, convém fazer uso de teorias que estudam a comunicação em geral, isto é, a comunicação não apenas restrita ao sistema jurídico.

198 “A textura aberta do direito significa que há, na verdade, áreas de conduta em que muitas coisas devem ser deixadas para serem desenvolvidas pelos tribunais ou pelos funcionários, os quais determinavam o equilíbrio, à luz das circunstâncias, entre interesses conflituantes de caso para caso. (...) Aqui, na franja das regras e no campo deixado em aberto pela teoria dos precedentes, os tribunais preenchem uma função criadora de regras que os organismos administrativos executam de forma centralizada na elaboração de padrões variáveis" (HART, Herbert L.A. O conceito de direito. 5.ed. Lisboa: Fundação Calouste Gulbekian, 2007, pp.148-149).

${ }^{199}$ Ao se tratar de um ordenamento jurídico em que há uma Constituição, que estabelece limites à legislação, deve-se destacar que a aplicação do direito não se refere somente à interpretação do juiz, mas à própria elaboração legislativa, como acima apontado ao se descrever a teoria kelseniana. Não obstante, um fator a ser considerado é que a aplicação do direito por meio do Legislativo apresenta menores limitações que a aplicação pelo Judiciário.

${ }^{200}$ HART, Herbert L.A. O conceito de direito. 5.ed. Lisboa: Fundação Calouste Gulbekian, 2007.

201 "If law is an interpretive concept, any jurisprudence worth having must be built on some view of what interpretation is" (DWORKIN, Ronald. Law's empire. Cambridge: Harvard, 1986, p. 50).

${ }^{202}$ CARRIÓ, Genaro R. Notas sobre derecho y lenguaje. 4. ed. Buenos Aires: Abeledo - Perrot, 1994.

203 “As normas só não bastam. Sua ambigüidade e vagueza (afinal elas se expressam por palavras) exigem também regras de interpretação. É preciso saber dizer não só qual é a norma, mas também o que ela significa" (FERRAZ JR., Tercio Sampaio. Introdução ao estudo do direito: técnica, decisão, dominação. 3. ed. São Paulo: Atlas, 2001, p. 49).

204 „Der Begriff der Norm ist einerd der Grundbegriffe der Jurisprudenz, wenn nicht der Grundbegriff dieser Wissenschaft überhaupt“ (ALEXY, Robert. Theorie der Grundrechte. Suhrkamp: Baden-Baden, 1994, p. 40). Complementando tal afirmativa e esclarecendo a diferença entre o texto normativo e a norma: „Daß zwischen Normsatz und Norm zu unterscheiden ist, lässt sich daran erkennen, dass dieselbe Norm durch verschiedene Normsätze ausgedrückt werden kann“ (ALEXY, Robert. Theorie der Grundrechte. Suhrkamp: Baden-Baden, 1994, p.43)

205 "So in the end, it is not the legal syllogism that alone determines the outcome of the case. Some or all of the terms in the statute will have to be interpreted, and the facts of the case must be interpreted and evaluated to see if they really count, if they really fit the statute. Reasons can and should be given for preferred interpretations that are decisive in a case. The rest of this book explores the issue, 'What sorts of reasons are appropriate to this task?' The reasons for reading the syllogism in a certain way are, it may be said, the real reasons of the case. They belong in a logic of probabilities, not certainties, so that is in the end the decisive logic of the matter" (MACCORMICK, Neil. Rhetoric and the rule of law: a theory of legal reasoning. Nova Iorque: Oxford, 2005, p. 42).

${ }^{206}$ FERRAZ JR., Tercio Sampaio. Introdução ao estudo do direito: técnica, decisão, dominação. 3. ed. São Paulo: Atlas, 2001, p. 260. 


\subsection{As funções da linguagem}

Se no campo do direito a comunicação e a linguagem usualmente são entendidas como sendo a expressão de um imperativo, isto é, uma comunicação voltada a atribuir um comando, a comunicação e a linguagem apresentam evidentemente diversos usos além deste. Dentre os outros usos da linguagem, pode-se mencionar, por exemplo, o uso da linguagem para descrever um objeto, o uso da linguagem para transmitir as emoções sentidas, ou até mesmo o uso da linguagem fazendo referência a ela mesma.

Mesmo sendo usos tão diferentes, todos apresentam uma forma de comunicação. Neste sentido, seria interessante que uma investigação a respeito destes usos da linguagem apontasse o fundamento para sua semelhança e diferença. Uma teoria que apresenta uma base satisfatória para tanto, segundo o nosso entendimento, é a teoria elaborada por Roman Jakobson, que se vale de trabalhos de outros teóricos, como Karl Bühler e Bronislaw Malinowski.

É possível começar a explanação desta teoria a partir dos fundamentos elaborados por Karl Bühler. Este parte de uma afirmação de Platão, segundo a qual, por meio da linguagem, um indivíduo se comunicaria com outro a respeito das coisas ${ }^{207}$. Desenvolvendo esta afirmação de Platão ${ }^{208}$, Bühler propõe o seguinte modelo ${ }^{209}$ :

207 "Creo que fue una buena presa de Platón la indicación que hace en el Cratilo de que el lenguaje es un organum para comunicar uno a otro algo sobre las cosas" (BÜHLER, Karl. Teoría del lenguaje. Madrid: Revista de Occidente, 1950, p. 36).

${ }^{208}$ Outro teórico - como o próprio Bühler aponta (BÜHLER, Karl. Sprachtheorie. 3.ed. Stuttgart: Lucius \& Lucius, 1999 p. 25) - que também desenvolveu essa idéia de Platão, foi Alan Gardiner, com seu The theory of speech and language de 1932.

${ }^{209}$ BÜHLER, Karl. Teoría del lenguaje. Madrid: Revista de Occidente, 1950, p. 40. 


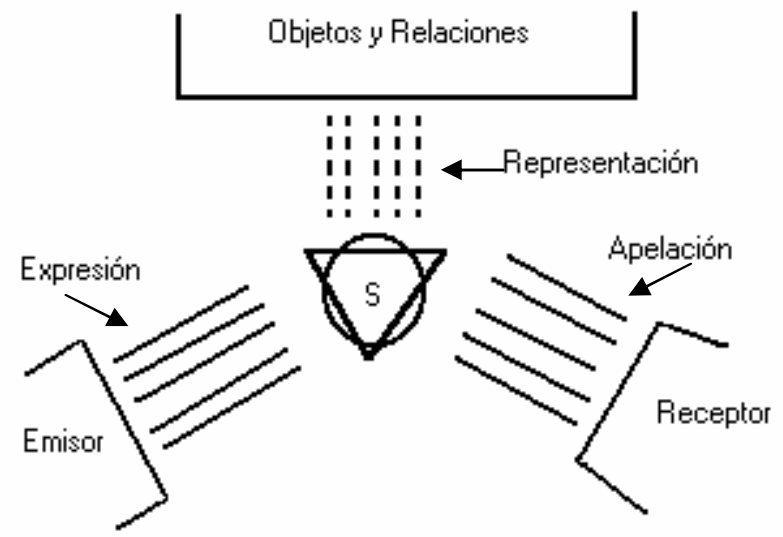

No modelo acima, o círculo representa o fenômeno acústico concreto. Seguindo a descrição daquele modelo, o triângulo se refere ao fato deste fenômeno ser um signo (e como tal, nesta concepção, pode ser um símbolo, um sintoma ou um sinal, como a seguir será exposto). Assim, o triângulo sob um aspecto compreende menos que o círculo, pois pode representar menos que este (princípio da relevância abstrativa). Por outro lado, compreende mais sob outro ponto de vista, indicando que a percepção pode acrescentar algo ao fenômeno acústico ${ }^{210}$. Finalmente, os grupos de linhas simbolizam as funções semânticas do signo lingüístico (apelação, expressão e representação ${ }^{211}$ ).

O signo, de acordo com essa visão, pode ser então um símbolo se fizer menção a “as coisas" (termo utilizado por Platão, o qual Bühler trata como "objetos e relações"212), será um sintoma se fizer referência ao emissor (Sender) e ou será um sinal se fizer relação receptor (Empfänger $)^{213}$. A cada um desses liga-se, respectivamente, uma função de

210 „Der Kreis in der Mitte symbolisiert das konkrete Schallphänomen. Drei variable Momente an ihm sind berufen, es dreimal verschieden zum Rang eines Zeichens zu erheben. Die Seiten des eingezeichneten Dreiecks symbolisieren diese drei Momente. Das Dreieck umschließt in einer Hinsicht weniger als der Kreis (Prinzip der abstraktiven Relevanz). In anderer Richtung wieder greift es über den Kreis hinaus, um anzudeuten, daß das sinnlich gegebene stets eine apperzeptive Ergänzung erfährt. Die Linienscharen symbolisieren die semantischen Funktionen des (komplexen) Sprachzeichens. Es ist Symbol kraft seiner Zuordnung zu Gegenständen und Sachverhalten, Symptom (Anzeichen, Indicium) kraft seiner Abhängigkeit vom Sender, dessen Innerlichkeit es ausdrückt, und Signal kraft seines Appells an den Hörer, dessen äußeres oder inneres Verhalten es steuert wie andere Verkehrszeichen“ (BÜHLER, Karl. Sprachtheorie. 3.ed. Stuttgart: Lucius \& Lucius, 1999 p. 28).

${ }^{211}$ No original, Appell, Ausdruck e Darstellung, respectivamente (BÜHLER, Karl. Sprachtheorie. 3.ed. Stuttgart: Lucius \& Lucius, 1999 p. 28).

${ }^{212}$ No original, Gegenstände und Sachverhalte, que poderia ser traduzida livremente como "objetos e situações" (BÜHLER, Karl. Sprachtheorie. 3.ed. Stuttgart: Lucius \& Lucius, 1999 p. 28).

213 "Es símbolo [grifo do autor] en virtud de su ordenación a objetos y relaciones; síntoma [grifo do autor] (indicio), en virtud de su dependencia del emisor, cuya interioridad expresa, y señal [grifo do autor] en virtud 
representação, expressão e apelação. Assim, pode-se construir esquematicamente o seguinte quadro:

\begin{tabular}{|c|c|c|}
\hline Elemento & Espécie de signo & Função \\
\hline Emissor & Sintoma & Expressiva \\
\hline Receptor & Sinal & Apelativa \\
\hline Objetos e relações & Símbolo & Representativa \\
\hline
\end{tabular}

No tocante à função de expressão, Bühler, em suas obras anteriores, denominavaa como "manifestação", enquanto a nomenclatura anterior para "apelação" era "repercussão",214. Aspecto interessante da teoria de Bühler e que deve ser ressaltado, referese à sua afirmação, que a comunicação apresentava simultaneamente aspectos de diferentes funções, sendo que haveria, contudo, um predomínio de uma delas (que na maior parte dos casos seria a representativa, segundo Bühler), o que acabaria por caracterizar, pois, a função de determinada comunicação. Ao predomínio da função expressiva corresponderia a lírica, enquanto ao predomínio da apelativa, corresponderia a retórica. Desse modo, tanto a lírica quanto a retórica seriam objeto da lingüística. Deve ser notado que Bühler apresenta em seu modelo um elemento (o signo) ao qual não atribui uma função específica.

Não obstante possíveis críticas à teoria em análise $\mathrm{e}^{215}$, deve-se destacar que Bühler não só cria uma base para o modelo de Jakobson, como será visto adiante, mas também acaba por ter repercussão na teoria jurídica ${ }^{216}$.

Outro pilar da teoria de Jakobson é colocado com a obra de Bronislaw Malinowski, que com base em sua pesquisa de campo realizada na Oceania, escreve o suplemento $O$ problema do significado em linguagens primitivas ${ }^{217}$ (The problem of

de se apelación al oyente, cuya conducta externa o interna dirige como otros signos de tráfico". BÜHLER, Karl. Teoría del lenguaje. Madrid: Revista de Occidente, 1950, p. 41.

${ }^{214}$ Argumenta Bühler, "la palabra latina appellare (inglés, appeal; alemán, ansprechen) es acertada para lo segundo [referência ao termo "apelação"]; hay, como hoy sabe todo el mundo, un sex-appeal, junto al cual el speech appeal me parece un hecho igualmente tangible" (BÜHLER, Karl. Teoría del lenguaje. Madrid: Revista de Occidente, 1950., p. 41).

${ }^{215}$ Por exemplo em relação ao predomínio da comunicação oral (fenômeno acústico) em seu modelo e à classificação dos signos, que apresenta uma certa tautologia (e.g. o signo é um sintoma porque a função é expressiva e esta é uma função expressiva porque o signo é um sintoma).

${ }^{216}$ Cf. CARRIÓ, Genaro R. Notas sobre derecho y lenguaje. 4. ed. Buenos Aires: Abeledo - Perrot, 1994, p. 39-41; FERRAZ JR., Tercio Sampaio. Direito, retórica e comunicação: subsídios para uma pragmática do discurso jurídico. 2. ed. São Paulo: Saraiva, 1997, pp. 13 e 74.

${ }^{217}$ MALINOWSKI, Bronislaw. O problema do significado em linguagens primitivas, in: OGDEN, C. K.; RICHARDS, I. A.. O significado de significado. Rio de Janeiro: Zahar, 1972, pp. 295-330. 
meaning in primitive languages ${ }^{218}$ ) para a obra $O$ significado de significado $^{219}$ (The meaning of meaning ${ }^{220}$ ). Neste suplemento, Malinowski além de criar as bases do conceito de função fática, acaba por criar uma interessante definição de contexto de situação. Segundo Malinowski, para traduzir a linguagem praticada por um grupo de nativos das ilhas Trobriand para o inglês, além de conhecer a tradução de uma palavra específica, seria necessário conhecer o conjunto de costumes e práticas locais das pessoas que praticam a língua em questão ${ }^{221}$.

Desse modo, Malinowski entende que nas linguagens "primitivas", o entendimento do significado de uma palavra seria muito dependente do seu contexto ${ }^{222}$. Para definir a que espécie de contexto que se refere, Malinowski apresenta uma definição específica. Segundo ele o "contexto de situação” (“context of situation”) seria:

\begin{abstract}
"an expression which indicates on one hand that the conception of context has to be broadened and on the other that the situation in which words are uttered can never be passed over as irrelevant to the linguistic expression. We see how the conception of context must be substantially widened, if it is to furnish us with its full utility. In fact it must burst the bonds of mere linguistics and be carried over into the analysis of the general conditions under which a language is spoken" ${ }^{, 223}$.
\end{abstract}

No entender de Malinowski, este contexto de situação seria aplicável somente à comunicação oral ${ }^{224}$ - e principalmente às linguagens primitivas -, de modo não serviria de

218 MALINOWSKI, Bronislaw. The problem of meaning in primitive languages, in: OGDEN, C. K.; RICHARDS, I. A. The meaning of meaning: a study of the influence of language upon thought and of the science of symbolism. Londres: Routledge, 1994, pp. 435-496;

${ }^{219}$ OGDEN, C. K.; RICHARDS, I. A. O significado de significado. Rio de Janeiro: Zahar, 1972.

${ }^{220}$ OGDEN, C. K.; RICHARDS, I. A. The meaning of meaning: a study of the influence of language upon thought and of the science of symbolism. Londres: Routledge, 1994.

221 "Instead of translating, of inserting simply an English word for a native one, we are faced by a long and not altogether simple process of describing wide fields of customs, of social psychology and of tribal organisation which correspond to one term or another" (MALINOWSKI, Bronislaw. The problem of meaning in primitive languages, in: OGDEN, C. K.; RICHARDS, I. A. The meaning of meaning: a study of the influence of language upon thought and of the science of symbolism. Londres: Routledge, 1994, p. 443).

${ }^{222}$ MALINOWSKI, Bronislaw. The problem of meaning in primitive languages, in: OGDEN, C. K.; RICHARDS, I. A. The meaning of meaning: a study of the influence of language upon thought and of the science of symbolism. Londres: Routledge, 1994, p. 449.

${ }^{223}$ MALINOWSKI, Bronislaw. The problem of meaning in primitive languages, in: OGDEN, C. K.; RICHARDS, I. A. The meaning of meaning: a study of the influence of language upon thought and of the science of symbolism. Londres: Routledge, 1994, p. 450 (grifo no original).

224 "Exactly as in the reality of spoken or written languages, a word without linguistic context is a mere fragment and stands for nothing by itself, so in the reality of a spoken living tongue, the utterance has no meaning except in the context of situation" (MALINOWSKI, Bronislaw. The problem of meaning in primitive languages, in: OGDEN, C. K.; RICHARDS, I. A. The meaning of meaning: a study of the influence 
referência aos textos escritos, que deveriam "conter" a mensagem no limite do texto ${ }^{225}$. Ademais, a linguagem em sua forma "primitiva" estaria mais relacionada à ação - isto é, como um comportamento humano em questões práticas - do que ao uso como instrumento de reflexão ou como forma de se refletir um pensamento ${ }^{226}$.

Outra forma de uso da linguagem, que poderia se verificar - não só nas linguagens "primitivas" - seria aquele em que a troca das palavras seria quase um fim em si mesmo ${ }^{227}$. Nesta forma de linguagem, Malinowski afirma que há uma aparência de as palavras estarem livres de qualquer contexto de situação ${ }^{228}$. Segundo a análise de Malinowski, as frases de polidez não estariam relacionadas a uma transmissão de pensamento e o significado das palavras seria quase irrelevante ${ }^{229}$.

$\mathrm{O}$ uso destas formas de linguagem estaria relacionado à tendência humana de se congregar, pois para um indivíduo, o silêncio de outro representaria algo inquietante e perigoso, de modo que a troca de palavras simples seria uma forma de romper o silêncio e

of language upon thought and of the science of symbolism. Londres: Routledge, 1994, p. 452 [grifo no original]).

225 "In fact, written statements are set down with the purpose of being self-contained and self-explanatory. A mortuary inscription, a fragment of primeval laws or precepts, a chapter or statement in a sacred book, or to take a more modern example, a passage from a Greek or Latin philosopher, historian or poet - one and all of these were composed with the purpose of bringing their message to posterity unaided, and they had to contain this message within their own bounds" (MALINOWSKI, Bronislaw. The problem of meaning in primitive languages, in: OGDEN, C. K.; RICHARDS, I. A. The meaning of meaning: a study of the influence of language upon thought and of the science of symbolism. Londres: Routledge, 1994, pp. 450-451).

${ }^{226}$ MALINOWSKI, Bronislaw. The problem of meaning in primitive languages, in: OGDEN, C. K.; RICHARDS, I. A. The meaning of meaning: a study of the influence of language upon thought and of the science of symbolism. Londres: Routledge, 1994, p. 459.

${ }^{227}$ MALINOWSKI, Bronislaw. The problem of meaning in primitive languages, in: OGDEN, C. K.; RICHARDS, I. A. The meaning of meaning: a study of the influence of language upon thought and of the science of symbolism. Londres: Routledge, 1994, p. 460.

228 "When a number of people sit together at a village fire, after all the daily tasks are over, or when they accompany some mere manual work by gossip quite unconnected with what they are doing - it is clear that here we have to do with another using in language, another type of speech function. Language here is not dependent upon what happens at that moment, it seems to be even deprived of any context of situation" (MALINOWSKI, Bronislaw. The problem of meaning in primitive languages, in: OGDEN, C. K.; RICHARDS, I. A. The meaning of meaning: a study of the influence of language upon thought and of the science of symbolism. Londres: Routledge, 1994, p. 461). Não parece plausível esta afirmação de Malinowski, segundo a qual esta forma de linguagem estaria livre de um contexto de situação, pois para a própria caracterização deste uso, Malinowski precisou "contextualizar" em que situação esta forma de uso da linguagem se verificaria. Assim, entendemos que mesmo este uso da linguagem é dependente de um contexto de situação, que não seria meramente criado pela troca de palavras, como sugerido por Malinowski (MALINOWSKI, Bronislaw. The problem of meaning in primitive languages, in: OGDEN, C. K.; RICHARDS, I. A. The meaning of meaning: a study of the influence of language upon thought and of the science of symbolism. Londres: Routledge, 1994, p. 464)

229 "A mere phrase of politeness, in use as much among savage tribes as in a European drawing room, fulfils a function to which the meaning of its words is almost completely irrelevant. Enquiries about health, comments on weather, affirmations of some supremely obvious state of things - all such are exchanged nor in order to inform, not in this case to express any thought" (MALINOWSKI, Bronislaw. The problem of meaning in primitive languages, in: OGDEN, C. K.; RICHARDS, I. A. The meaning of meaning: a study of the influence of language upon thought and of the science of symbolism. Londres: Routledge, 1994, p. 461). 
aproximar os indivíduos ${ }^{230}$. Para esta forma de uso da linguagem, Malinowski acaba cunhando uma nova expressão: comunhão fática (phatic communion ${ }^{231}$ ). Deve-se destacar que "fática" não se refere à palavra "fato", tendo origem no grego phatos (falado) ou phatikos (afirmando) ${ }^{232}$. No presente estudo é utilizada a palavra com a grafia "fática" em vez de "phática", dado que já existe uma série de trabalhos, como a tradução do texto de Jakobson, que acabaram utilizando esta forma de tradução - destaque-se que a tradução do texto de Malinowski por vezes se refere à "prática",233 ou a "pática",234, sendo ambas traduções equivocadas.

Baseando-se nestes estudos de Bühler e de Malinowski, Jakobson elabora, pois, sua teoria das funções da linguagem em seu estudo Línguística e poética ${ }^{235}$ (Closing statement: linguistics and poetics $\left.{ }^{236}\right)$, em que procura mostrar que a poética seria uma função da linguagem e deste modo integraria a lingüística ${ }^{237}$. Ao lado desta função, haveria outras funções, sendo que cada uma delas estaria relacionada a um determinado elemento da comunicação.

\footnotetext{
230 "Speech is the intimate correlate of this tendency, for, to a natural man, another man's silence is not a reassuring factor, but, on the contrary, something alarming and dangerous. The stranger who cannot speak the language is to all savage tribesmen a natural enemy. To the primitive mind, whether among savages or own uneducated classes, taciturnity means not unfriendliness but directly a bad character. This no doubt varies greatly with the national character but remains true as a general rule. The breaking of silence, the communion of words is the first act to establish links of fellowship, which is consummated only by the breaking of bread and the communion of food" (MALINOWSKI, Bronislaw. The problem of meaning in primitive languages, in: OGDEN, C. K.; RICHARDS, I. A. The meaning of meaning: a study of the influence of language upon thought and of the science of symbolism. Londres: Routledge, 1994, p. 462).

${ }^{231}$ MALINOWSKI, Bronislaw. The problem of meaning in primitive languages, in: OGDEN, C. K.; RICHARDS, I. A. The meaning of meaning: a study of the influence of language upon thought and of the science of symbolism. Londres: Routledge, 1994, p. 463.

${ }^{232}$ Confira a definição de "phatic" apresentada pelo dicionário Oxford: "phatic. adj. (of language) used for general social interaction rather to convey specific meaning, e.g. nice morning, isn't it?

Origin 1920s: from Gk phatos 'spoken' or phatikos 'affirming"'(PEARSALL, Judy [Ed.]. Concise oxford english dictionary. 10. ed. Nova Iorque: Oxford, 2002, p. 1071).

${ }^{233}$ MALINOWSKI, Bronislaw. O problema do significado em linguagens primitivas, in: OGDEN, C. K.; RICHARDS, I. A.. O significado de significado. Rio de Janeiro: Zahar, 1972, p. 295.

${ }^{234}$ MALINOWSKI, Bronislaw. O problema do significado em linguagens primitivas, in: OGDEN, C. K.; RICHARDS, I. A.. O significado de significado. Rio de Janeiro: Zahar, 1972, p. 311.

${ }^{235}$ JAKOBSON, Roman. Lingüística e poética, in: JAKOBSON, Roman. Lingüística e comunicação. São Paulo: Cultrix, 2001, pp. 118-162.

${ }^{236}$ JAKOBSON, Roman. Closing statement: linguistics and poetics, in: SEBEOK, Thomas [Org.]. Style in language. Nova Iorque: Wiley, 1960, pp. 350-377.

237 "Insistence on keeping poetics apart from linguistics is warranted only when the field of linguistics appears to be illicitly restricted, for example, when the sentence is viewed by some linguists as the highest analyzable construction or when the scope of linguistics is confined to grammar alone or uniquely to nonsemantic questions of external form or to the inventory of denotative devices with no reference to free variations" (JAKOBSON, Roman. Closing statement: linguistics and poetics, in: SEBEOK, Thomas [Org.]. Style in language. Nova Iorque: Wiley, 1960, p. 352).
} 
Estes elementos presentes na comunicação seriam, segundo a teoria mais elaborada de Jakobson ${ }^{238}$, uma mensagem, produzida por um remetente, em um determinado código e certo contexto, endereçada a um destinatário, sendo que haveria um contato entre o emissor e o destinatário ${ }^{239}$. Em conjunto, poderiam ser assim esquematicamente representados ${ }^{240}$ :

\section{Contexto}

Remetente Destinatário
Contacto
Código

Neste modelo, Jakobson se aproveita de alguns elementos propostos por Bühler remetente, destinatário -, além de outros dois elementos, que sofrem alterações. O "signo" no modelo de Bühler se torna a "mensagem", no modelo proposto por Jakobson, enquanto que o "contexto" se refere às "objetos e relações" propostos anteriormente. A estes elementos, Jakobson integra o "contato", que havia sido proposto por Malinowski e acrescenta o "código".

Sendo estes os elementos da comunicação, Jakobson segue também a proposta de Bühler e relaciona a cada um deles uma função da linguagem. Como Bühler, Jakobson também afirma que dificilmente a comunicação se restringiria somente a uma função ${ }^{241}$,

\footnotetext{
${ }^{238}$ Em uma elaboração prévia de sua teoria (JAKOBSON, Roman. A linguagem comum dos lingüistas e dos antropólogos, in: JAKOBSON, Roman. Lingüística e comunicação. São Paulo: Cultrix, 2001, p. 19), Jakobson expõe somente cinco elementos, sem mencionar o contato entre o emissor e o destinatário. Além de ser prévia, esta teoria não foi a que veio a ser consagrada, dado que o modelo incluindo o contato é o mais difundido.

239 "Before discussing the poetic function we must define its place among the other functions of language. An outline of these functions demands a concise survey of the constitutive factors in any speech event, in any act of verbal communication. The ADDRESSER sends a MESSAGE to the ADDRESSEE. To be operative, the message requires a CONTEXT ('referent' in another, somewhat ambiguous nomenclature), seizable by the addressee, and either verbal or capable of being verbalized; a CODE fully or at leas partially, common to the addresser and addressee (or in other words, to the encoder and the decoder of the message); and finally, a CONTACT, a physical channel and psychological connection between the addresser and the addressee, enabling both of them to enter and stay in communication" (JAKOBSON, Roman. Closing statement: linguistics and poetics, in: SEBEOK, Thomas [Org.]. Style in language. Nova Iorque: Wiley, 1960, p. 353).

${ }^{240}$ JAKOBSON, Roman. Lingüística e poética, in: JAKOBSON, Roman. Lingüística e comunicação. São Paulo: Cultrix, 2001, p. 123.

241 "Each of these six factors determines a different function of language. Although we distinguish six basic aspects of language, we could, however, hardly find verbal messages that would fulfil only one function" (JAKOBSON, Roman. Closing statement: linguistics and poetics, in: SEBEOK, Thomas [Org.]. Style in language. Nova Iorque: Wiley, 1960, p. 353)
} 
sendo que normalmente apresentaria elementos de outras funções, tendo apenas um pendor (Einstellung) para um ou outro elemento.

De acordo com a nomenclatura proposta por Jakobson, este pendor para cada elemento se ligaria a uma determinada função, como pode ser indicado resumidamente na tabela abaixo.

\begin{tabular}{|c|c|}
\hline Elemento da comunicação & Função correspondente \\
\hline Remetente & Emotiva \\
\hline Destinatário & Conativa \\
\hline Contexto & Referencial \\
\hline Contato & Fática \\
\hline Mensagem & Poética \\
\hline Código & Metalingüística \\
\hline
\end{tabular}

Como se percebe, Jakobson renomeia as funções da linguagem que Bühler havia anteriormente identificado: "expressiva" se torna "emotiva", "apelativa" passa a ser denominada "conativa", "representativa" ganha a nomenclautura "referencial”. Em relação à função fática, Jakobson faz menção à "comunhão fática” proposta por Malinowski ${ }^{242}$. Já a função metalingüística seria inspirada na diferenciação proposta por Niels Bohr entre linguagem-objeto e metalinguagem ${ }^{243}$. Finalmente, entre as funções da linguagem resta uma função, isto é, a função poética, que vem a ser justamente o centro da análise do capítulo de Jakobson.

Após estas observações iniciais, pode-se abordar de maneira sucinta cada uma das funções da linguagem. Dentre as funções da linguagem, a que mais se relacionaria ao direito, de acordo com a noção difundida de a norma ser um comando ou imperativo, é a função conativa. Esta tem um pendor no destinatário da mensagem e sua forma mais usual

\footnotetext{
${ }^{242}$ Em relação aos usos da linguagem, Malinowski apresenta uma outra classificação, diferenciando entre o ativo o narrativo e o ritual, sendo que este útlimo corresponderia à magia (MALINOWSKI, Bronislaw. $O$ problema do significado em linguagens primitivas. In: OGDEN, C. K.; RICHARDS, I. A.. O significado de significado. Rio de Janeiro: Zahar, 1972, p. 319)

243 JAKOBSON, Roman. Aspectos lingüísticos da tradução, in: JAKOBSON, Roman Lingüística e comunicação. São Paulo, Cultrix, 2001, p. 67.
} 
é o imperativo, cuja veracidade, ao contrário das orações declarativas, não é passível de ser questionada $^{244}$.

Em oposição à maior facilidade de se encontrar a função conativa no direito, a função da linguagem que seria mais difundida em geral - isto é, não somente no discurso jurídico - seria a função referencial ${ }^{245}$, isto é que teria um predomínio do elemento do contexto. Isto se verificaria, por exemplo, quando a comunicação descrevesse o que acontece ao redor dos participantes.

Ainda relacionada aos elementos inicialmente apontados por Bühler, haveria a função emotiva, isto é, aquela que teria o foco no remetente. Uma forma de manifestação da função emotiva seria a interjeição. Outra forma possível seria o remetente deixar o discurso marcado por ironia ou ainda pelo uso particularizado de algumas expressões, isto é, em vez de se utilizar a palavra "grande", destacar o tamanho utilizando-se a expressão "graaande" 246 .

No que concerne à função fática, Jakobson se refere a Malinowski e indica que seu uso serviria para estabelecer ou prolongar um contato ou para verificar o canal entre o remetente e o destinatário, bem como para chamar a atenção. Assim, Jakobson acaba por relacionar a função fática ao elemento do contato entre o remetente e o destinatário. Ademais, o mencionado autor afirma que a função fática também se verificaria em bebês que teriam uma tendência de se comunicar antes de serem capazes de transmitir ou receber informação - ou até mesmo em aves ${ }^{247}$. Destaque-se que após os estudos empreendidos por Jakobson, houve desenvolvimentos na teoria da comunicação fática, segundo o qual uma interpretação seria considerada fática, se a partir dela fossem tiradas conclusões que não dependessem do conteúdo explícito de uma determinada manifestação ${ }^{248}$. Outra

\footnotetext{
${ }^{244}$ The imperative sentences cardinally differ from declarative sentences: the latter are and the former are not liable to a truth test. When in O'Neil's play The Fountain, Nano, '(in a fierce tone of command)', says 'Drink!' - the imperative cannot be challenged by the question 'is it true or not?' which may be, however, perfectly well asked after such sentences as 'one drank', 'one will drink', 'one would drink'” (JAKOBSON, Roman. Closing statement: linguistics and poetics, in: SEBEOK, Thomas [Org.]. Style in language. Nova Iorque: Wiley, 1960, p. 355)

${ }^{245}$ JAKOBSON, Roman. Closing statement: linguistics and poetics, in: SEBEOK, Thomas [Org.]. Style in language. Nova Iorque: Wiley, 1960, p. 353.

${ }^{246}$ JAKOBSON, Roman. Closing statement: linguistics and poetics, in: SEBEOK, Thomas [Org.]. Style in language. Nova Iorque: Wiley, 1960, p. 354.

${ }^{247}$ JAKOBSON, Roman. Closing statement: linguistics and poetics, in: SEBEOK, Thomas [Org.]. Style in language. Nova Iorque: Wiley, 1960, pp. 355-356.

248 "An interpretation is phatic to the extent that it contains implicated conclusions which do not depend on the explicit content of the utterance" (ŽEGARAC, Vlad; CLARK, Billy. Phatic interpretations and phatic communication, in: Journal of Linguistics, Vol. 35, N 2, Julho de 1999, p. 331).
} 
observação em relação à comunicação fática, que, contudo, não é pacífica ${ }^{249}$, refere-se ao fato de a probabilidade de a função fática ser maior, caso a relação entre o remetente e o destinatário não esteja plenamente estabelecida ${ }^{250}$.

Com foco em outro elemento da comunicação, qual seja, o código, destaca-se a função metalingüística no modelo de Jakobson. O traço característico da função metalingüística seria sua comunicação referente à própria linguagem e a ela estaria oposto o uso da linguagem-objeto. Além de seu uso pelos lingüistas e lógicos, a função metalingüística, teria seu uso no dia a dia, quando é necessário que os participantes de um diálogo verifiquem se utilizam o mesmo código, o que poderia ocorrer, por exemplo, quando um deles fizesse uso de uma gíria ou expressão que o outro não conhecesse e tivesse que explicar qual o significado da expressão ${ }^{251}$.

Finalmente, em relação à função destacada por Jakobson - a função poética -, é de se notar que seu pendor está relacionado à própria mensagem. Esta função não seria a limitada à poesia e nem mesmo a única forma de arte verbal ${ }^{252}$. Nela, haveria uma preocupação entre a combinação de seleção de palavras que se referem ao mesmo tópico. Por exemplo, para o tópico ao qual a palavra "animal" se refere, poderiam ser utilizadas, além desta palavra, outras semelhantes como "bicho", "criatura", "ser" ou "fera", que poderiam ser combinadas a outras expressões de outro tópico, "se alimentar", "devorar", “comer", "encher o bucho", entre outras. Na função poética, assim a preocupação com a seleção recairia sobre a combinação entre as palavras, isto é, a característica da função poética seria a projeção do "princípio de equivalência do eixo de seleção sobre o eixo de

\footnotetext{
249 Veja a crítica (falta de apoio empírico) em WARD, Greogory; HORN, Laurence R.. Phatic communication and relevance theory: a reply to Žegarac \& Clark, in: Journal of Linguistics, Vol. 35, Novembro de 1999, p. 560. Para a resposta (necessidade de utilização de uma parcela de intuição), veja ŽEGARAC, Vlad; CLARK, Billy. Phatic communication and Relevance Theory: a reply to Ward \& Horn, in: Journal of Linguistics, Vol. 35, N 3, Novembro de 1999, p. 569.

250 ŽEGARAC, Vlad; CLARK, Billy. Phatic interpretations and phatic communication, in: Journal of Linguistics, Vol. 35, $\mathrm{N}^{\circ}$ 2, Julho de 1999, p. 329.

${ }^{251}$ Metalanguage is not only a necessary scientific tool utilized by logicians and linguists; it plays also an important role in our everyday language. Like Molière's Jourdain who used prose without knowing it, we practice metalanguage without realizing the metalingual character of our operations. Whenever the addresser and/or the addressee need to check up whether they use the same code, speech is focused on the CODE: it performs a METALINGUAL (i.e. glossing) function. 'I don't follow you - what do you mean' asks the addressee (...). And the addresser in anticipation of such recapturing questions inquiries: 'Do you know what I mean?"' (JAKOBSON, Roman. Closing statement: linguistics and poetics, in: SEBEOK, Thomas [Org.]. Style in language. Nova Iorque: Wiley, 1960, p. 356).

${ }^{252}$ JAKOBSON, Roman. Closing statement: linguistics and poetics, in: SEBEOK, Thomas (Org.). Style in language. Nova Iorque: Wiley, 1960, p. 356.
} 
combinação" ${ }^{\text {253 }}$. Desse modo, além de estar parcialmente presente nos diálogos cotidianos, a função poética também poderia se verificar nos slogans ${ }^{254}$.

\subsection{A linguagem jurídica e o contexto}

Para a utilização destas funções da linguagem no âmbito jurídico, é necessário adotar cautela, dado que a linguagem jurídica apresenta diferenças significativas em relação à forma de linguagem acima abordada. Uma primeira diferença refere-se ao fato de os estudos acima mencionados se referirem principalmente à comunicação entre remetente e destinatário que se encontram fisicamente em contato. De maneira contrária, a linguagem jurídica, que é o foco da presente análise - isto é, a legislação -, caracteriza-se por ser primordialmente uma comunicação por meio escrito, em que o remetente e o destinatário não se encontram em contato direto ${ }^{255}$.

Ademais, a linguagem jurídica busca ser técnica, tentando reduzir a vagueza apresentada pela linguagem natural ${ }^{256}$. Desse modo, ao menos em parte, a linguagem do direito estaria neutralizada e seria possível determinar a sua aplicação independentemente de particularidades. Entretanto, ainda que haja uma redução das imprecisões da linguagem natural pela linguagem jurídica, esta redução não chega ao ponto de ser uma completa eliminação, de modo que a análise desenvolvida para a linguagem natural pode ser considerada de forma mitigada para a linguagem jurídica ${ }^{257}$.

253 JAKOBSON, Roman. Lingüística e poética, in: JAKOBSON, Roman. Lingüística e comunicação. São Paulo: Cultrix, 2001, p. 130. Ou no original: "what is the empirical linguistic criterion of the poetic function? In particular, what is the indispensable feature inherent in any piece of poetry? To answer this question we must recall the two basic modes of arrangement used in verbal behaviour, selection and combination. If 'child' is the topic of the message, the speaker selects one among the extant, more or less similar, nouns like child, kid, youngster, tot, all of them equivalent in a certain respect, and then, to comment on this topic, he may select one of semantically cognate verbs - sleeps, dozes, nods, naps. Both chosen words combine in the speech of chain. The selection is produced on the base of equivalence, similarity and dissimilarity, synonymity and antonymity, while the combination, the build up of the sequence is based on contiguity. The poetic function projects the principle of equivalence from the axis of selection into the axis of combination. Equivalence is promoted to the constitutive device of the sequence" (JAKOBSON, Roman. Closing statement: linguistics and poetics, in: SEBEOK, Thomas [Org.]. Style in language. Nova Iorque: Wiley, 1960, p. 358).

${ }^{254}$ Um exemplo de slogan com origem na política norte-americana, que é mencionado por Jacobson é "I like Ike" (JAKOBSON, Roman. Closing statement: linguistics and poetics, in: SEBEOK, Thomas [Org.]. Style in language. Nova Iorque: Wiley, 1960, p. 357). Em relação à política brasileira, entendemos um exemplo de slogan em que a função poética estaria presente seria a expressão "Lula lá".

${ }^{255}$ Mesmo a linguagem jurídica pode ser oral e ocorrer quando remetente e destinatário e se encontram em contato direto. Exemplo disso é a celebração de um contrato de compra e venda para o qual não haja forma prescrita, podendo o mesmo ser celebrado verbalmente.

${ }^{256}$ Vide acima 4.1 .

${ }^{257}$ Neste sentido, Malinowski em seu estudo já entendia que o uso "científico" da linguagem estaria marcado por traços do desenvolvimento da linguagem: "Of course the more highly developed a language is and the 
No que se refere ao argumento da ausência de contato, como visto acima ${ }^{258}$, Malinowski indica que os textos escritos deveriam conter a sua mensagem por si próprios, isto é, de maneira independente do contexto. A este argumento, pode-se contrapor que mesmo um texto escrito pode vir a ser entendido de maneira inadequada, caso seu contexto não seja considerado. Por exemplo, um texto escrito nos Estados Unidos no começo do século XX, utilizando as palavras "negro" ou "black", para se referir aos indivíduos com origem no continente africano, deverá ser entendido de maneira diferente, caso o mesmo texto fosse escrito nos dias atuais - que, para não transmitir uma mensagem racista, provavelmente utilizaria "African-American" ou "Afro-American". Note-se que se o termo "black" poderia gerar dúvidas e poderia mesmo eventualmente ser aceito, a adoção do termo "negro" seria uma menção clara a uma orientação preconceituosa, não sendo aceito de forma alguma na atualidade. O mesmo ocorre na Alemanha com a palavra "Reichstag", que deverá ser entendida de um modo, caso contida em um escrito do final do século XIX, ou de outra, caso contida em um escrito atual que não se refira ao prédio histórico do parlamento alemão, mas ao parlamento alemão - neste último caso indicaria uma conotação neonazista.

No que concerne aos textos jurídicos, a importância do contexto também não pode ser ignorada. Desse modo, a visão que limita a importância do contexto para o texto normativo, pode ser tida como superada, ainda que haja eventualmente alguém que defenda uma aplicação literal da legislação. Neste sentido, mesmo a doutrina que não é exatamente recente já reconhecia que a interpretação jurídica deveria atentar para o contexto em que a legislação havia sido elaborada:
"A fim de descobrir o alcance eminentemente prático do texto, coloca-se o intérprete na posição do legislador: procura saber por que despontou a necessidade e qual foi primitivamente o objeto provável da regra, escrita ou consuetudinária; põe a mesma em relação com todas as circunstâncias determinantes do seu aparecimento, as quais, por isso mesmo fazem ressaltar as exigências morais,

\footnotetext{
longer its evolutional history, the more structural strata it will embody. The several stages of culture savage, barbarous, semi-civilised and civilised; the various type of use - pragmatic, narrative, ritual, scholastic, theological - will each have left its mark. And even the final, powerful, but by no means omnipotent purification by scientific use, will in no way be able to obliterate the previous imprints. The various structural peculiarities of a modern, civilised language carry (...) an enormous dead-weight of archaic use, of magical superstition and of mystical vagueness" (MALINOWSKI, Bronislaw. The problem of meaning in primitive languages, in: OGDEN, C. K.; RICHARDS, I. A. The meaning of meaning: a study of the influence of language upon thought and of the science of symbolism. Londres: Routledge, 1994, p. 483). ${ }^{258}$ Vide acima 4.2.
} 
políticas e sociais, econômicas e até mesmo técnicas, a que os novos dispositivos deveriam satisfazer; estuda, em suma o ambiente social e jurídico em que a lei surgiu; os motivos da mesma, a sua razão de ser; as condições históricas apreciáveis como causa imediata da promulgação, ${ }^{, 259}$.

Desse modo, ao menos o contexto do remetente passa a ser considerado. Há teóricos do direito que defendem que somente este contexto deveria ser considerado, a partir do qual a intenção original (original intent) dos que criaram o texto poderia ser compreendida. Entre estes teóricos, destaca-se Bork, que sustenta que esta forma de interpretação, em especial com relação à interpretação da constituição, seria a única forma de limitar o poder judicial ${ }^{260}$. Desse modo, ao julgar um caso, o magistrado poderia extrair uma premissa maior do contexto em que a constituição havia sido elaborada ${ }^{261}$ e deste modo não adentraria no papel do legislador ${ }^{262}$.

Um bom exemplo de como o contexto em que a mensagem é emitida é extremamente relevante para a interpretação normativa é fornecido por Warat. Segundo seu exemplo, a expressão "proibido usar tanga", apresentada em uma praia de Ipanema - e segundo o nosso entendimento, em uma placa afixada em um estabelecimento praiano, como um restaurante - traz um conteúdo normativo, enquanto a mesma expressão, em uma praia de nudismo, fará alusão à norma totalmente diferente ${ }^{263}$.

Entretanto, como nos textos escritos não há necessariamente nem contato direto entre remetente e destinatário, nem um contexto comum aos dois, é provável que o contexto do destinatário também possa influenciar a percepção da comunicação normativa.

\footnotetext{
${ }^{259}$ MAXIMILIANO, Carlos. Hermenêutica e interpretação do direito. 19. ed. Rio de Janeiro: Forense, 2004, p. 122 .

260 "The only way in which the Constitution can constrain judges is if the judges interpret the document's words according to the intentions of those who drafted, proposed and ratified its provisions and its various amendments" (BORK, Robert H.. The Constitution, original intent and economic rights, in: BORK, Robert H.. A time to speak: selected writings and arguments. Wilmington: ISI Books, 2008, p. 262).

261 "In short, all an intentionalist requires is that the text, structure, and history of the Constitution provide him not with a conclusion, but with a major premise. That premise states a core value that the Framers intended to protect" (BORK, Robert H.. The Constitution, original intent and economic rights, in: BORK, Robert H.. A time to speak: selected writings and arguments. Wilmington: ISI Books, 2008, p. 263)

262 "The conclusion, I think, must be that only by limiting themselves to the historic intentions underlying each clause of the Constitution can judges avoid becoming legislators, avoid enforcing their own moral predilections, and ensure that the Constitution is law. For the subject of economic rights, that means we must turn away from the glamour of abstract of philosophic discourse and back to the mundane and difficult task of discovering what the framers were trying to accomplish with the Contract Clause and the Takings Clause" (BORK, Robert H.. The Constitution, original intent and economic rights, in: BORK, Robert H.. A time to speak: selected writings and arguments. Wilmington: ISI Books, 2008, p. 269)

${ }^{263}$ WARAT, Luis Alberto. O direito e sua linguagem. 2. ed. Porto Alegre: Fabris, 1995, p. 67.
} 
Neste sentido, Ferraz Jr. integra o intérprete ao processo comunicativo, colocando-o em uma posição privilegiada em relação aos demais participantes ${ }^{264}$.

Deste modo, o contexto do destinatário também passa a importar para a interpretação normativa. Entretanto, faz-se mister caracterizar a qual contexto se faz referência. Diversos autores aludem a um "contexto" na interpretação, sem detalhar com maior precisão, a que "contexto" fazem referência. Por exemplo, Canotilho faz menção a um "contexto socioeconômico",265 e a um "contexto de situação",266 , mas não define estas expressões.

Com efeito, entendemos que a definição de "contexto" é extremamente importante. Inicialmente, entendemos que uma palavra apresenta um "significado de base", isto é um núcleo de situações e objetos ao qual faz referência, de maneira independente de contexto.

A seguir, esta palavra apresenta em seu uso um "contexto lingüístico", isto é o contexto da palavra em uma consideração da mensagem e das mensagens que a ela fazem referência. Assim, se uma palavra for definida em um significado específico ${ }^{267}$, este será o seu contexto linguiístico. Se o contexto a ser considerado não for o lingüístico, mas a realidade em que o discurso ocorre, este será o "contexto de situação". Este seria o caso, por exemplo, em que uma pessoa em um prédio em chamas grita "água", fazendo um pedido para que o fogo seja apagado, pouco importando se isso ocorra por meio de água ou com um extintor com base em outro princípio. Deste modo, podemos nos valer de definição por nós anteriormente apresentada:

“Definimos 'significado de base' como o significado central de um termo, sem consideração de nenhum contexto; 'contexto lingüístico' como o conjunto de termos e frases que se relacionam a um termo e que podem interferir em seu significado de base e 'contexto de situação', como a relação entre o texto e a

\footnotetext{
264 “A situação comunicativa normativa é, pois, caracterizada pela presença de três comunicadores, sendo que entre os comunicadores sociais e o terceiro se instaura uma interação, cujas regras fundamentais privilegiam a posição do último" (FERRAZ JR., Tercio Sampaio. Teoria da norma jurídica: ensaio da pragmática da comunicação normativa. Rios de Janeiro: Forense, 1978, p. 39).

${ }^{265}$ CANOTILHO, José Joaquim Gomes. Constituição dirigente e vinculação do legislador: contributo para a compreensão das normas constitucionais programáticas. 2.ed. Coimbra: Coimbra, 2001, p. 29.

${ }^{266}$ CANOTILHO, José Joaquim Gomes. Constituição dirigente e vinculação do legislador: contributo para a compreensão das normas constitucionais programáticas. 2.ed. Coimbra: Coimbra, 2001, p. 424.

${ }^{267} \mathrm{O}$ que pode se dar por meio da função metalingüística. Isto ocorreria quando um texto fixasse a definição de uma determinada palavra ( pela palavra "X", entenda-se "Y").
} 
realidade para a qual este vai ser aplicado - evidentemente, se ao longo do tempo a realidade sofrer alterações, sua relação com o texto também se modificará,268.

Como anteriormente mencionado, deve-se destacar que pode haver uma diferença entre o contexto de situação que existia à época em que o texto foi produzido e aquele que existe quando da interpretação do texto, o que deve ser notado pela interpretação ${ }^{269}$. Ademais, uma alteração do contexto lingüístico também pode ocorrer. Como ambos o contextos são importantes para a definição da função da linguagem, uma explicação mais detalhada desta questão conduz a abordagem para o próximo tópico.

\subsection{As funções da linguagem aplicadas ao direito}

Em continuidade a análise acima exposta, deve-se atentar que a aplicação das funções da linguagem pressupõe cautela. Procedendo desta maneira, é possível perceber que o texto normativo pode apresentar diferentes funções da linguagem, de acordo com a análise do contexto lingüístico e do contexto de situação do remetente e do destinatário.

Neste sentido, é importante atentar para quais são os elementos presentes na comunicação normativa, em especial para a comunicação fundada pela legislação em sentido amplo, isto é, abrangendo também outras formas de diplomas legislativos, como a Constituição, Decretos, Regulamentos, Portarias, entre outros. Nesta forma de comunicação, o primeiro elemento que pode ser destacado é o remetente.

Este elemento, em um caso de uma Portaria ou Circular, pode ser caracterizado pela posição ser ocupada por um remetente singular. No entanto, o remetente pode se referir a um conjunto que representa uma concreta multiplicidade de emissores, como ocorre no caso de uma Lei, que mesmo sendo proposta por um membro do Congresso, depende da concordância de um conjunto de pessoas (o Congresso) e, na maioria dos casos, de outros envolvidos (e.g. Presidente da República, que pode vetar em parte ou completamente um projeto de lei aprovado no Congresso).

\footnotetext{
${ }^{268}$ FISCHMANN, Filipe. A função fática na Constituição Federal. Tese de Láurea apresentada à Faculdade de Direito da Universidade de São Paulo. São Paulo: 2006, p. 54.

${ }^{269}$ Esta consideração da alteração de contexto de situação também pode alterar não só a interpretação da legislação, mas também a interpretação de precedentes: "The cyclical and political nature of the IP-antitrust interface makes it difficult to know exactly what the law is. Many of the cases discussed in this treatise are relatively old, and belong to an era very different than the one in which we currently find ourselves. They are nonetheless often the only cases that discuss a particular practice. These cases should therefore be read with caution, not because they are necessarily bad law, but because they need to be understood in their historical and economic context" (HOVENKAMP, Herbert; JANIS, Mark D.; LEMLEY, Mark A. IP and antitrust: an analysis of antitrust principles applied to intellectual property law. Austin: Aspen, 2002, p. 1-17).
} 
Entretanto, mesmo nestas hipóteses em que há mais de um envolvido na emissão da mensagem normativa, costuma-se falar em apenas um "legislador". Desse modo, quando se menciona que o "legislador" é o remetente da mensagem normativa, faz-se alusão ao legislador racional, isto é, uma construção dogmática da "língua hermenêutica",270.

O segundo elemento da comunicação em geral é o destinatário. A posição deste elemento no modelo da comunicação normativa pode ser ocupado por ao menos duas espécies diferentes de participantes da comunicação. O primeiro participante a que a norma pode se referir é o próprio cidadão ou indivíduo que se encontra no âmbito de vigência da mensagem normativa, por exemplo, um estrangeiro que se encontre em território nacional, que também deve ser portar de acordo com o ordenamento jurídico pátrio, sob pena de arcar com o imputado pela norma. Outro destinatário possível de uma mensagem normativa é algum órgão estatal, que pode receber competência para aplicar o direito - e que, desta forma, também poderá ser remetente de mensagem normativas, que poderão ter como destinatário outro órgão ou os cidadãos e outros indivíduos.

Em relação ao elemento do código, este corresponde à linguagem criada pelo direito. Como acima apontado, a linguagem normativa se vale de aspectos da linguagem natural, mas apresenta contornos próprios. Este aspecto da linguagem normativa ficará mais claro abaixo, quando se exemplificar a função da linguagem que a ela se liga, isto é, a função metalingüística.

O correspondente para o elemento da mensagem na comunicação em geral, é o texto normativo no modelo da comunicação normativa. Deve-se destacar que a mensagem não é a norma, porque esta depende de uma análise de todos os fatores envolvidos na comunicação. Pelas características da comunicação normativa, o elemento da mensagem (o texto normativo) acaba por influenciar de maneira usualmente preponderante a percepção da própria norma. Entretanto, tal característica não justifica que se identifique a norma como o elemento da mensagem, pois tal postura acabaria por evidenciar uma confusão entre "texto normativo" e "norma", sendo que esta já é uma diferenciação consolidada para a teoria hermenêutica jurídica.

No que se refere ao elemento do contexto, como exposto acima, este pode se referir ao contexto lingüístico, ao contexto de situação do remetente e ao contexto de situação do destinatário, sendo que estes últimos podem ser idênticos. O contexto

${ }^{270}$ FERRAZ JR., Tercio Sampaio. Introdução ao estudo do direito: técnica, decisão, dominação. 3. ed. São Paulo: Atlas, 2001, pp. 275-276. 
lingüístico na comunicação normativa seria aquele que se refere ao texto normativo considerado como um todo - isto é o conjunto do texto normativo de um ordenamento jurídico. O contexto de situação do remetente aponta para as condições existentes que se pretende regular e que fundamentam o surgimento do texto normativo, enquanto o contexto de situação do destinatário se refere às condições existentes à época de aplicação da norma.

Finalmente, o elemento do contato na comunicação normativa se refere à relação entre remetente e destinatário. Para a caracterização do elemento do contato na comunicação normativa, convém destacar o modelo proposto por Ferraz Jr., com apoio nos estudos desenvolvidos por Watzlawick, Beavin e Jackson ${ }^{271}$. Ferraz Jr. afirma que a norma apresenta dois níveis de comunicação, o cometimento e o relato ${ }^{272}$. Neste modelo teórico, o cometimento corresponde a relação entre o emissor e o receptor das mensagens, sendo que esta relação é uma relação de autoridade/sujeito ${ }^{273}$. Para que apresente caráter jurídico, é necessário que esta relação ${ }^{274}$ de autoridade seja institucionalizada ${ }^{275}$, isto é, esteja garantida contra a desconfirmação ${ }^{276}$.

Desse modo, os elementos presentes na comunicação normativa foram expostos, restando entender quais são as funções da linguagem se relacionam a eles. Desenvolvendo esta análise, em estudo anterior já apontamos que a função fática poderia ser encontrada na Constituição Federal brasileira ${ }^{277}$. De maneira sintética, o que expusemos anteriormente, refere-se à circunstância de a função fática ser vinculada ao elemento do contato, de modo que um exemplo de mensagem normativa que, no contexto atual é entendido como função fática, é a determinação constitucional do salário mínimo:

271 WATZLAWICK, Paul; BEAVIN, Janet Helmick; JACKSON, Don D. Pragmática da Comunicação humana: um estudo dos padrões, patologias e paradoxos da interação. São Paulo: Cultrix, 2001, p. 47 e ss.

${ }^{272}$ FERRAZ JR., Tercio Sampaio. Introdução ao estudo do direito: técnica, decisão, dominação. 3. ed. São Paulo: Atlas, 2001, p. 105.

273 "Essa relação, no caso do cometimento das normas ou comunicação normativa, é baseada na diferença (entre os comunicadores), e é uma relação complementar (um manda, outro obedece; um recomenda, outro acata; um coordena, outro se enquadra etc.). A relação complementar manifesta uma espécie de controle do receptor pelo emissor" (FERRAZ JR., Tercio Sampaio. Introdução ao estudo do direito: técnica, decisão, dominação. 3. ed. São Paulo: Atlas, 2001, p. 106 [grifo no original]).

${ }^{274}$ Destaque-se que para apresentar o caráter jurídico, a norma também precisa apresentar uma conformidade de conteúdo (FERRAZ JR., Tercio Sampaio. Introdução ao estudo do direito: técnica, decisão, dominação. $3^{\mathrm{a}}$ ed. São Paulo: Atlas, 2001, p. 108 e ss.). Neste tópico da análise, contudo, há um foco no elemento da relação entre remetente e destinatário, de modo que esta é desenvolvida com maior minúcia.

${ }^{275}$ No que concerne à institucionalização, vide o exposto a respeito da teoria desenvolvida por Luhmann no item 2.1.

${ }^{276}$ FERRAZ JR., Tercio Sampaio. Introdução ao estudo do direito: técnica, decisão, dominação. 3. ed. São Paulo: Atlas, 2001, pp. 106-107.

${ }^{277}$ FISCHMANN, Filipe. A função fática na Constituição Federal. Tese de Láurea apresentada à Faculdade de Direito da Universidade de São Paulo. São Paulo: 2006. 


\title{
Constituição da República Federativa do Brasil
}

Título II - Dos Direitos e Garantias Fundamentais

Capítulo II - Dos Direitos Sociais

\begin{abstract}
Art. $7^{\circ}$ São direitos dos trabalhadores urbanos e rurais, além de outros que visem à melhoria de sua condição social:

IV - salário mínimo, fixado em lei, nacionalmente unificado, capaz de atender a suas necessidades vitais básicas e às de sua família com moradia, alimentação, educação, saúde, lazer, vestuário, higiene, transporte e previdência social, com reajustes periódicos que lhe preservem o poder aquisitivo, sendo vedada sua vinculação para qualquer fim.
\end{abstract}

Em relação à parte que define que o salário mínimo deve atender às necessidades vitais básicas do trabalhador e de sua família, deve-se destacar que no atual contexto sócioeconômico, esta mensagem é entendida como função fática. Isto é, dado que seu valor ${ }^{278}$ fica longe de poder satisfazer todas as necessidades de um trabalhador e mais longe ainda de poder atender às necessidades de uma família, a disposição constitucional é entendida por seus aplicadores como um aspecto a promover uma aproximação entre o remetente (constituinte) e o destinatário (camadas menos favorecidas da população ${ }^{279}$ ).

Destaque-se que se o salário mínimo fosse fixado em valor que pudesse atender a todos os parâmetros elencados pelo texto constitucional (saúde, educação, lazer, etc) por uma simples alteração legislativa que ocorresse de uma só vez, tal fixação teria repercussões negativas que trariam problemas para que se observasse outras medidas constitucionais. Este valor elevado por esta simples alteração legislativa, que aumentasse o salário brutalmente - e no caso atual, mesmo que o valor fosse dobrado, ele continuaria a não ser suficiente para satisfação dos parâmetros enumerados -, geraria dificuldades não só para as empresas arcarem com os salários, o que poderia aumentar o número de

\footnotetext{
${ }^{278}$ Atualmente fixado em $\mathrm{R} \$ 510,00$ pelo Art. $1^{\circ}$, inciso I da Medida Provisória 474 de 23 de dezembro de 2009.

${ }^{279}$ Ainda que haja outros destinatários (e.g. Executivo Federal e Legislativo Federal, que devem fixar o valor do salário mínimo), o contato é enfocado na relação com os possíveis beneficiários da medida, que ao menos poderiam se sentir como reconhecidos na Constituição.
} 
trabalhadores empregados informalmente, ou até mesmo levar ao aumento no desemprego. Ademais, o próprio Estado teria dificuldades para atender ao referido valor, dado que por força do Art. 201, §2 da Constituição Federal é notório o impacto causado na Previdência Social pelo aumento do salário mínimo. O referido aumento também afetaria o Poder Público de outra maneira, já que principalmente os Municípios com pequeno orçamento teriam dificuldade de arcar com um salário elevado para seus funcionários. Ademais, outros impactos negativos, que poderiam inclusive anular os benefícios do aumento, seriam possíveis de se verificar, como um aumento acentuado na inflação.

Deste modo, percebe-se que o contexto de situação promove uma alteração do significado, que poderia ser abstraído do significado de base das palavras do texto constitucional ou mesmo do significado considerado o contexto lingüístico, de modo que a aplicação do texto constitucional acaba por caracterizar a função fática ${ }^{280}$.

Passando para a análise de outra função da linguagem, poderia se destacar a presença da função conativa no direito, isto é, aquela que apresenta o foco no destinatário. Como o maior exemplo desta função da linguagem é o imperativo, um dispositivo como o Art. 121 do Código Penal ${ }^{281}$ poderia caracterizar a função conativa, seja entendido como um imperativo aos membros da população para que não cometam o homicídio, seja como um imperativo aos aplicadores do direito (no caso do homicídio, em primeira instância o Tribunal do Júri), para que verificada a ocorrência de um homicídio, deveriam aplicar a pena cominada pelo Código Penal (reclusão de seis a vinte anos).

Já a função emotiva, isto é, a função com foco no remetente, não é fácil de encontrar na legislação em geral. Contudo, ao menos como uma função presente lembrando que a comunicação pode (e costuma) apresentar aspectos concomitantes de diversas funções da linguagem - no Preâmbulo da Constituição Federal brasileira:

"Nós, representantes do povo brasileiro, reunidos em Assembléia Nacional Constituinte para instituir um Estado Democrático, destinado a assegurar o exercício dos direitos sociais e individuais, a liberdade, a segurança, o bem-estar, o desenvolvimento, a igualdade e a justiça como valores supremos de uma sociedade fraterna, pluralista e sem preconceitos, fundada na harmonia social e

\footnotetext{
${ }^{280}$ Exemplo da dificuldade em se lidar com a questão da aplicação deste dispositivo pode ser verificada em Acórdão do STF, prolatada por ocasião do julgamento da Medida Cautelar na Ação Direta de Inconstitucionalidade 1439/DF, julgada em 22 de maio de 1996, publicada no DJ de 30 de maio de 2003, cujo relator foi o Ministro Celso de Mello.

281 "Homicídio simples - Art 121. Matar alguém:

Pena - reclusão, de seis a vinte anos".
} 
comprometida, na ordem interna e internacional, com a solução pacífica das controvérsias, promulgamos, sob a proteção de Deus, a seguinte CONSTITUIÇÃO DA REPÚBLICA FEDERATIVA DO BRASIL” (nosso grifo).

Outra função dificilmente encontrada no direito seria a função poética, dado que normalmente a preocupação com a seleção das palavras não está relacionada à combinação entre elas, mas a uma maior precisão terminológica. Não obstante, a função poética poderia ser verificada ao menos em parte no Art. 600 do revogado Código Civil de 1916:

"Pertence ao pescador o peixe, que pescar, e o que arpoado ou farpado, perseguir, embora outrem o colha".

Neste dispositivo, percebe-se que há uma repetição da letra "p", o que acaba atribuindo um certo ritmo à mensagem. Mensagem de semelhante conteúdo normativo também poderia ter sido emitida, sem que a referida repetição ocorresse. Exemplo disso seria uma formulação como: “O peixe que for pescado caberá àquele que o pescou, assim como o peixe atingido que for seguido por aquele que o atingiu, ainda que outrem o colha". Deste modo, ao menos em parte é possível de se identificar uma preocupação em projetar o princípio de equivalência do eixo da seleção de palavras para o eixo da combinação das mesmas.

Quanto à função metalingüística, pode-se afirmar que a mesma é empregada freqüentemente no ordenamento jurídico. Esta, caracterizada por ser uma linguagem a respeito da própria linguagem, estaria presente no direito em todos os dispositivos que fazem referência à definições e redefinições jurídicas. Exemplo disso pode ser encontrado nos Arts. $2^{\circ}$ e $3^{\circ}$ da Lei 8078 de 11 de setembro de 1990:

“Art. $2^{\circ}$ Consumidor é toda pessoa física ou jurídica que adquire ou utiliza produto ou serviço como destinatário final.

Parágrafo único. Equipara-se a consumidor a coletividade de pessoas, ainda que indetermináveis, que haja intervindo nas relações de consumo.

Art. $3^{\circ}$ Fornecedor é toda pessoa física ou jurídica, pública ou privada, nacional ou estrangeira, bem como os entes despersonalizados, que desenvolvem atividade de produção, montagem, criação, construção, transformação, importação, exportação, distribuição ou comercialização de produtos ou prestação de serviços.

$\S 1^{\circ}$ Produto é qualquer bem, móvel ou imóvel, material ou imaterial. 
$\S 2^{\circ}$ Serviço é qualquer atividade fornecida no mercado de consumo, mediante remuneração, inclusive as de natureza bancária, financeira, de crédito e securitária, salvo as decorrentes das relações de caráter trabalhista".

Com efeito, para a legislação consumerista, "consumidor" não é qualquer pessoa ou entidade que tire proveito de um "produto" ou "serviço", sendo "consumidor" somente aquele que o fizer como destinatário final - destaque-se que, ao valer-se da palavra "consumidor", a teoria do direito concorrencial o faz em sentido diferente. Neste sentido, a definição de "consumidor" na legislação de proteção ao consumidor acaba por apresentar um significado próprio, caracterizando a função metalingüística. É de se ressaltar que uma alteração no que foi definido pela função metalingüística é de fundamental importância, dado que, pelo contexto lingüístico, semelhante mudança pode repercutir em vários dispositivos que se valham da definição apresentada. Assim, ainda que por si só a mera definição de "consumidor" não apresente relevância prática, esta definição é de fundamental importância se considerada em conjunto com as outras disposições. Deste modo, a aplicação da referida Lei poderia ser ampliada ou reduzida, dependendo de apenas uma alteração da definição apresentada.

Finalmente, resta analisar a função referencial, isto é, a função da linguagem que apresenta um pendor para o contexto. Usualmente, esta função apresenta um caráter descritivo, de modo que, na comunicação normativa, poderia ser caracterizada nas mensagens que apresentassem caráter meramente declarativo, sem apresentar caráter constitutivo. Como alguma espécie de caráter constitutivo costuma estar presente, esta função da linguagem também deve ser analisada na comunicação normativa em conjunto com outras funções, como a função referencial. Considerada deste modo, poderia se entender que dispositivos que enunciassem o contexto em que determinada disposição surge, como os "Considerandos" de um Tratado ou Regulamento na União Européia representariam uma forma de função referencial. 


\section{ANÁLISE ECONÔMICA DO DIREITO DIANTE DA TEORIA RETÓRICA}

O capítulo anterior, buscando empreender uma discussão dos limites e possibilidades da aplicação do direito, apresentou uma análise do direito como fenômeno comunicativo, discutindo as funções da linguagem, bem como a questão do contexto, oferecendo algumas das relações dessas funções com a norma jurídica, apresentando assim um modelo desenvolvido com base em diversos autores, e que será empregado a seguir no tratamento do foco deste trabalho. Assim, este capítulo procura investigar como este modelo a respeito da comunicação normativa pode ser compatível com uma análise econômica do direito e, como o fazendo, acaba por impor limites a esta análise. Com efeito, a próxima etapa deste estudo passa a se ocupar com a questão dos limites impostos por uma teoria retórica do direito a uma análise econômica do direito.

5.1 Limites de uma interpretação pautada pela análise econômica do direito

Como anteriormente exposto, a vertente de análise econômica do direito atualmente mais difundida defende que o direito deve se pautar pela eficiência, sendo esta entendida primordialmente segundo o modelo de Kaldor-Hicks. Este modelo foi mais desenvolvido para a interpretação de precedentes, mas isso não significa que esta corrente teórica não tenha desenvolvido um método de interpretação para a legislação. Neste sentido, para se apurar os limites que a análise econômica do direito pode apresentar, convém destacar a teoria de interpretação proposta por Posner, para, em um momento seguinte, compará-la com o modelo desenvolvido no capítulo anterior.

Iniciando a explanação de seu modelo, Posner afirma que a interpretação judicial é um fator intrínseco à teoria econômica da legislação ${ }^{282}$. Em um primeiro desenvolvimento teórico a respeito da interpretação judicial, Posner sustenta que os magistrados não teriam como apurar os motivos que deram origem a uma lei, por não

\footnotetext{
282 "That the economist takes statutes to be complete when enacted is striking to a lawyer, who realizes that the meaning of a statute is not fixed until the courts have interpreted the statute. Judicial interpretation of statutes is thus an intrinsic part of a complete economic theory of legislation, though whether an important part remains to be seen" (POSNER, Richard A.. Economics, politics, and the reading of statutes and the Constitution, in: The University of Chicago law review, Vol. 49, $\mathrm{N}^{\circ} 2$, primavera de 1982, p. 264).
} 
terem os instrumentos necessários para tanto ${ }^{283}$, devendo se limitar a apurar a intenção (intent) da lei, como anteriormente mencionado. Uma exceção ocorreria quando a própria legislação, ou ao menos os registros do debate histórico fossem explícitos em apontar uma orientação para a futura interpretação do dispositivo legal em questão ${ }^{284}$.

Em outro artigo em que desenvolve o tema da interpretação, Posner apresenta uma versão mais aprofundada a respeito da análise do texto normativo. Segundo seu entendimento do que aconteceria efetivamente na prática, o "cânone" segundo o qual o juiz deveria partir do texto normativo para efetuar sua interpretação não se justificaria, pois raramente um magistrado começaria sua análise a partir deste elemento, sendo que freqüentemente este elemento seria até mesmo ignorado ${ }^{285}$, uma vez que na prática da common law, muitas vezes os magistrados se reteriam somente aos precedentes ${ }^{286}$. Entretanto, Posner não nega a importância que o texto normativo possa ter para a interpretação, reconhecendo que usualmente este seria o meio mais adequado para se entender qual era o próposito da legislação, sendo que sua crítica se dirigiria principalmente à necessidade de começar a interpretação sempre a partir do texto normativo $^{287}$.

283 "Courts look to the language of the statute, to the legislative history, and to other evidence of legislative intent, but they do not speculate on the motives of the legislators in enacting the statute. 83 They do not, in short, conduct the kind of economic or political science inquiry that might reveal the pattern of interest group pressures behind the statute. (...)

At first glance it may seem diametrically opposed to a realistic view of the political process and may seem to place the judiciary in opposition to the legislative will, even when there is no issue of constitutionality. In fact it is merely inevitable. Courts do not have the research tools that they would need to discover the motives behind legislation" (POSNER, Richard A.. Economics, politics, and the reading of statutes and the Constitution, in: The University of Chicago law review, Vol. 49, N², primavera de 1982, p. 272 [notas de rodapé omitidas]).

284 "If the legislature wants to indicate the lines of political pressure along which the law should be interpreted, it has to say so explicitly, either in the statute or in the legislative history materials to which courts have ready access. No matter how faithfully judges wish to carry out the will of Congress, they are limited to public materials in divining that will" (POSNER, Richard A.. Economics, politics, and the reading of statutes and the Constitution, in: The University of Chicago law review, Vol. 49, $\mathrm{N}^{\circ} 2$, primavera de 1982 , p. 273).

285 "The judge rarely starts his inquiry with the words of the statute, and often, if the truth be told, he does not look at the words at all" (POSNER, Richard A.. Statutory interpretation: in the classroom and in the courtroom, in: The University of Chicago law review, Vol. 50, $\mathrm{N}^{\circ} 2$, primavera de 1983, pp. 807-808).

286 "There are many statutes of which this is also true. The one I know best is the Sherman Act. Lawyers and judges do not begin their analyses of a challenged practice by comparing the practice with the language of the Act and, only if they have satisfied themselves that there is some relationship, then proceed to analyze the case law. They start with the case law and may never return to the statutory language-to 'restrain trade or commerce' or to 'attempt or conspire to monopolize"' (POSNER, Richard A.. Statutory interpretation: in the classroom and in the courtroom, in: The University of Chicago law review, Vol. 50, $\mathrm{N}^{\circ} 2$, primavera de 1983, p. 808 [notas de rodapé omitidas]).

287 "Of course the words of a statute are always relevant, often decisive, and usually the most important evidence of what the statute was meant to accomplish. I merely object to the proposition that one must always begin with the words, and I am reasonably confident that more often than not the judge - the good judge as well as the bad judge - in fact begins somewhere else" (POSNER, Richard A.. Statutory 
Deste modo, Posner propõe que a atividade interpretativa judicial deveria se pautar em uma reconstrução imaginária que buscasse o que o legislador teria querido como aplicação da $1 \mathrm{e}^{288}$ - esta seria aquela busca pela intenção (intent) da lei, que não se confundiria com os seus motivos (e.g. interesses de um determinado grupo de pressão). Adotando esta postura, o juiz estaria atento ao texto normativo, bem como aos registros do debate de surgimento da lei, mas também passaria a enfocar outros critérios, sendo o primeiro deles os valores e atitudes que estavam presentes na época de elaboração da lei, de modo que diferenças entre os valores atuais e os valores daquela época fossem levados em consideração ${ }^{289}$. Já o segundo elemento, que também seria levado em consideração seria a tentativa de perceber traços no texto normativo, que indicassem se a proposição poderia ser interpretada com maior ou menor liberdade ${ }^{290}$.

Desse modo, o texto do Sherman Act tenderia a indicar uma maior liberdade de interpretação para o conceito de restrição aos negócios (restraint of trade), enquanto o dispositivo que determina a idade mínima de 35 anos para o Presidente tenderia a ser interpretado mais restritivamente ${ }^{291}$. Mesmo neste caso do requisito da idade mínima, Posner sustenta que as palavras do dispositivo deveriam ser entendidas em seu contexto ${ }^{292}$. Outro elemento que poderia dar uma maior liberdade para a interpretação seria o tempo transcorrido entre sua elaboração e sua interpretação, pois seria difícil de reconstruir todas

interpretation: in the classroom and in the courtroom, in: The University of Chicago law review, Vol. 50, $\mathrm{N}^{\circ}$ 2, primavera de 1983, p. 808).

288 "I suggest that the task for the judge called upon to interpret a statute is best described as one of imaginative reconstruction. The judge should try to think his way as best he can into the minds of the enacting legislators and imagine how they would have wanted the statute applied to the case at bar" (POSNER, Richard A.. Statutory interpretation: in the classroom and in the courtroom, in: The University of Chicago law review, Vol. 50, $\mathrm{N}^{\circ}$ 2, primavera de 1983, p. 817 [nota de rodapé omitida]).

289 "One is the values and attitudes, so far as they are known today, of the period in which the legislation was enacted. It would be foolish to ascribe to legislators of the 1930's or the 1960's and early 1970's the scepticism regarding the size of government and the efficacy of regulation that is widespread today, or to impute to the Congress of the 1920's the current conception of conflicts of interest. It is not the judge's job to keep a statute up to date in the sense of making it reflect contemporary values; it is his job to imagine as best he can how the legislators who enacted the statute would have wanted it applied to situations that they did not foresee" (POSNER, Richard A.. Statutory interpretation: in the classroom and in the courtroom, in: The University of Chicago law review, Vol. 50, $\mathrm{N}^{\circ} 2$, primavera de 1983, p. 818).

${ }^{290}$ POSNER, Richard A.. Statutory interpretation: in the classroom and in the courtroom, in: The University of Chicago law review, Vol. 50, $\mathrm{N}^{\circ}$ 2, primavera de 1983, p. 818.

${ }^{291}$ POSNER, Richard A.. Statutory interpretation: in the classroom and in the courtroom, in: The University of Chicago law review, Vol. 50, $\mathrm{N}^{\circ} 2$, primavera de 1983, p. 818.

292 "It is not that the words are plain; it is that the words, read in context as words must always be read in order to yield meaning, do not authorize any interpretation except the obvious one" (POSNER, Richard A.. Statutory interpretation: in the classroom and in the courtroom, in: The University of Chicago law review, Vol. 50, $\mathrm{N}^{\circ}$ 2, primavera de 1983, p. 819). 
as condições que deram ensejo à legislação, de modo que a interpretação judicial destes dispositivos tenderia a ser entendida como sendo mais "desprendida" ("loose") ${ }^{293}$.

Um elemento ao qual a interpretação deveria dar pouca ou nehuma importância seria uma eventual manifestação por parte de algum participante do processo legislativo, após a lei ser promulgada. O motivo para isso seria que o acordo entre os participantes do processo legislativo já teria sido concluído e uma manifestação posterior não poderia ser considerada em peso diferente ao que havia obtido quando da negociação para a aprovação do documento legal em questão ${ }^{294}$.

Outro aspecto ao qual o juiz deveria atentar ao interpretar um dispositivo legal seria a possibilidade de o mesmo ser fruto de um compromisso entre grupos diferentes que não conseguiram chegar a um acordo específico. Nestes casos, inicialmente Posner defende que o compromisso deveria ser considerado quando da aplicação legal, de modo que o magistrado atribuísse uma solução intermediária ao dispositivo ${ }^{295}$, isto é, em vez de aplicar um determinado ponto de vista de um grupo de legisladores, a interpretação deve seguir à solução de compromisso ${ }^{296}$. Eventualmente uma solução de compromisso não apresentaria uma decisão a um determinado caso, sendo que nestas hipóteses o juiz poderia tomar uma decisão sem se referir ao processo legislativo, dado que esta atitude seria inevitável ${ }^{297}$.

Em relação à interpretação de documentos que expressem uma solução de compromisso, Posner manifesta entendimento diferente em outro estudo. O ponto de partida desta abordagem seria o fato de que o processo legislativo apresentaria elevados

293 "It is extraordinarily difficult to ascertain the intent of a document drafted two hundred years ago or, as in the case of the fourteenth amendment, even one hundred years ago. The cultural, political, and even linguistic setting is so altered that reconstructing the intent behind the constitutional provisions becomes a task of historical research. Judges do not have the time or the training to do such difficult research; even when it is done by competent legal historians it often yields highly uncertain results. If the intended meaning of a provision is difficult to recover because of the passage of time, any construction of the provision (except one that denies it any contemporary application at all) will seem 'loose' to opponents of that construction" (POSNER, Richard A.. Economics, politics, and the reading of statutes and the Constitution, in: The University of Chicago law review, Vol. 49, $\mathrm{N}^{\circ} 2$, primavera de 1982, p. 283).

${ }^{294}$ POSNER, Richard A.. Economics, politics, and the reading of statutes and the Constitution, in: The University of Chicago law review, Vol. 49, $\mathrm{N}^{\circ}$ 2, primavera de 1982, p. 275.

295 "Another facet of the same point, which I have discussed elsewhere, is that the absence of effective statutory remedies for violations of statutory commands should not automatically be considered an invitation to judges to create such remedies. The statute may reflect a compromise between those who wanted it to be fully effective in achieving its stated objective and those who wanted a less effective statute; if so, it should be enforced according to that compromise" (POSNER, Richard A.. Economics, politics, and the reading of statutes and the Constitution, in: The University of Chicago law review, Vol. 49, $\mathrm{N}^{\circ} 2$, primavera de 1982, $\mathrm{p}$. 809).

${ }^{296}$ POSNER, Richard A.. Economics, politics, and the reading of statutes and the Constitution, in: The University of Chicago law review, Vol. 49, $\mathrm{N}^{\circ}$ 2, primavera de 1982, p. 820.

${ }^{297}$ POSNER, Richard A.. Economics, politics, and the reading of statutes and the Constitution, in: The University of Chicago law review, Vol. 49, $\mathrm{N}^{\circ}$ 2, primavera de 1982, p. 820. 
custos de transação, dado que pressuporia uma negociação entre diversas partes (destacadamente os membros do legislativo) ${ }^{298}$. Deste modo, uma forma de reduzir os custos para se chegar a um acordo, seria reduzir a profundidade do mesmo - o que Posner denomina de "agree on less" -, o que acabaria deixando necessariamente uma parte das questões a ser resolvida pela interpretação judicial ${ }^{299}$. Como consequiência, caso os magistrados adotassem uma interpretação literal do texto normativo, eles acabariam por aumentar os custos de transação do processo legislativo e, na visão de Posner, em vez de aumentar a influência do legislativo, tenderiam a diminuí-la, pois o âmbito de aplicação das leis ficaria reduzido ${ }^{300}$.

Uma vez exposta este modelo de interpretação judicial segundo a visão de Posner, é interessante proceder ao questionamento relativo, se esta concepção de interpretação judicial poderia ser operacionalizada em um ordenamento jurídico como o brasileiro com a finalidade de promover a eficiência - como preceituado pelo aspecto normativo da análise econômica do direito preceituada pela Escola de Chicago. Isto é, passa-se, a seguir, à investigação da possibilidade de implementação prática dos resultados defendidos pela vertente normativa de análise ecônomica do direito, no ordenamento jurídico brasileiro, sem que esta análise normativa desconsidere aspectos positivos da análise econômica do direito. Em outras palavras, questiona-se se os principais preceitos da interpretação judicial no Brasil permitem uma promoção da eficiência segundo o critério de Kaldor-Hicks ou, alternativamente, segundo o critério de Pareto.

No Brasil a interpretação judicial costuma dedicar maior atenção ao texto normativo do que aos casos anteriormente decididos. Deve-se destacar, contudo, que a jurisprudência passou a ganhar mais destaque nos últimos anos por meio de instrumentos variados, como, por exemplo, a Súmula Vinculante ${ }^{301}$ e o requisito da Repercussão Geral

\footnotetext{
298 "The production of statutes may seem a straightforward process compared to the production of precedents as by-product of litigation. But then why has so much law remained judge-made rather than statutory? In fact, the costs of statutory production of rules are high. The enactment of a statute requires the agreement of a majority of the legislators, and transaction costs are high when there are hundreds of parties to the transaction" (POSNER, Richard A.. Economic analysis of law. 7. ed. Nova Iorque: Aspen, 2007, p. 586).

299 "The costs of legislative enactment imply that statures will often be ambiguous. After all, one way to reduce the cost of agreement is to agree on less - to leave difficult issues for future resolution by the courts" (POSNER, Richard A.. Economic analysis of law. 7. ed. Nova Iorque: Aspen, 2007, p. 586).

300 "This implies in turn that if courts adopt a policy of narrow interpretation of legislation (strict construction), they will reduce the effective output of the legislature by the reducing the scope of each statute. Thus judicial literalists, rather than being faithful servants of the legislature as they pretend to be, increase the cost of the legislative process by making legislators have to legislate more to cover the same ground. A related paradox is that the more costly legislative enactment is, the broader are statutory rules likely to be and hence the greater the judges latitude of interpretation" (POSNER, Richard A.. Economic analysis of law. 7. ed. Nova Iorque: Aspen, 2007, p. 586).

${ }^{301}$ Vide o Art. 103-A da Constituição Federal e a Lei 11417 de 19 de dezembro de 2006.
} 
como critério para a admissão de Recurso Extraordinário ${ }^{302}$ no Supremo Tribunal Federal, como também a súmula impeditiva de recursos, segundo a qual até mesmo a análise do tribunal de segunda instância pode ser dispensada ${ }^{303}$. Não obstante, a importância da legislação ainda é superior à atribuída a jurrisprudência, de modo que o texto normativo também desempenha um papel de destaque.

É de se observar, nesse sentido, que a análise do registro histórico do processo legislativo não é usual na interpretação judicial. Em outras palavras, esta análise pode até mesmo eventualmente ocorrer, mas tal atenção ao processo legislativo não ocorre com freqüência. Deste modo, no que concerne ao critério da reconstrução imaginária do legislador, a interpretação judicial no Brasil estaria em parte adequada à forma de interpretação proposta por Posner, por dar atenção ao texto legal, mas não satisfaria o critério de maior atenção ao registro histórico do processo legislativo, que poderia oferecer subsídios para compreender o contexto do remetente, contando assim com mais subsídios para reconstruir sua intenção.

No que se refere ao elemento de indicações no texto normativo a respeito da maior ou menor liberdade em sua interpretação, é de se destacar que este é um elemento que se encontra usualmente na legislação e que costuma ser observado pelos magistrados em sua interpretação. Assim freqüentemente se encontram expressões que indicam que a interpretação deve ser mais restritiva, ou também expressões que buscam ampliar o âmbito de aplicação da legislação. Este último poderia ser exemplificado por meio de menção a condutas não especificadas (e.g. caput do Art. $21^{304}$ da Lei 8884 de 11 de junho de 1994), enquanto um exemplo da primeira categoria seria uma interpretação restritiva dos negócios jurídicos envolvendo direitos autorais (Art. 4º da Lei 9610 de 19 de fevereiro de 1998).

Ademais, no Brasil também se encontram disposições no texto normativo que por si só tendem a reduzir a possibilidade de diversidade na interpretação, como a própria disposição que estabelece a idade mínima de 35 anos para o Presidente da República (Art. $14, \S 3^{\circ}$, inciso VI, a da Constituição Federal $^{305}$ ). Entretanto, mesmo uma disposição como

\footnotetext{
${ }^{302}$ Vide o Art. $102, \S 3^{\circ}$ da Constituição Federal, bem como o Arts. 543-A e 543-B do Código de Processo Civil.

${ }^{303}$ Vide o Arts. 518, $\$ 1^{\circ}$ do Código de Processo Civil.

304 “Art. 21. As seguintes condutas, além de outras, na medida em que configurem hipótese prevista no art. 20 e seus incisos, caracterizam infração da ordem econômica" (nosso grifo).

305 "Art. 14. A soberania popular será exercida pelo sufrágio universal e pelo voto direto e secreto, com valor igual para todos, e, nos termos da lei, mediante: (...)

$\S 3^{\circ}$ - São condições de elegibilidade, na forma da lei: (...)

VI - a idade mínima de:

a) trinta e cinco anos para Presidente e Vice-Presidente da República e Senador".
} 
esta possibilita a abertura de um debate interpretativo, como, por exemplo, ao se questionar qual seria o marco importante (por exemplo, data da inscrição da candidatura, dia da eleição, data da diplomação ou somente o dia da posse?) para que a idade mínima de 35 anos seja aferida.

Além destas disposições, o ordenamento jurídico brasileiro também possui dispositivos que indicam uma postura a ser adotada pelo magistrado ao interpretar a legislação em geral. Como principais dispositivos com este caráter, destaca-se o Art. 126 do Código de Processo Civil ${ }^{306}$, que determina que o juiz é obrigado a decidir mesmo em caso de lacuna ou obscuridade, além de determinar que os julgamentos se pautem na aplicação de "normas legais" e, em sua ausência, na analogia, nos costumes e nos princípios gerais do direito. Resumidamente, pode-se afirmar que o dispositivo mencionado positiva os princípios do pensar dogmático, isto é, a inegabilidade dos pontos de partida (aplicação das "normas legais") e vedação ao non liquet ou a compulsoriedade de uma decisão (o que no dispositivo se dá pela obrigação de uma decisão, mesmo nos casos de lacuna ou obscuridade) $)^{307}$.

Para o caso de omissão, os critérios elencados pelo art. 126 do Código de Processo Civil também são estabelecidos pelo Art. $4^{\circ}$ do Decreto-Lei No 4657 de 4 de setembro de 1942 (Lei de Introdução ao Código Civil) ${ }^{308}$. Este mesmo diploma legal também traz outro dispositivo, que indica critérios para a aplicação da lei. Trata-se de seu Art. $5^{0309}$, que determina que a aplicação judicial deverá se pautar pela busca dos "fins sociais" a que a lei se dirige, bem como observar os ditames do "bem comum".

Ainda que não se confunda com o critério de reconstrução imaginária do legislador proposto por Posner, a busca dos "fins sociais" aos quais a lei se dirige, pode se aproximar deste critério, se for entendido que a busca de intenção do legislador se confunde com os fins destinados pela lei. Feita esta aproximação, o método de interpretação proposto por Posner poderia ser considerado adequado à conciliação da busca da eficiência - como preceituado pela análise normativa - com o respeito aos limites interpretativos propostos por aquele autor, desde que se pudesse identificar uma igualdade

\footnotetext{
306 “Art. 126. O juiz não se exime de sentenciar ou despachar alegando lacuna ou obscuridade da lei. No julgamento da lide caber-lhe-á aplicar as normas legais; não as havendo, recorrerá à analogia, aos costumes e aos princípios gerais de direito".

${ }^{307}$ Para este dois parâmetros do pensamento dogmático, vide FERRAZ JR., Tercio Sampaio. Introdução ao estudo do direito: técnica, decisão, dominação. 3. ed. São Paulo: Atlas, 2001, p. 260.

308 "Art. $4^{\circ}$ Quando a lei for omissa, o juiz decidirá o caso de acordo com a analogia, os costumes e os princípios gerais de direito".

${ }^{309}$ Art. $5^{\circ}$ do Decreto-Lei N 4657 de 4 de setembro de 1942 (Lei de Introdução ao Código Civil): "Na aplicação da lei, o juiz atenderá aos fins sociais a que ela se dirige e às exigências do bem comum”.
} 
de significados entre as exigências do bem comum e a busca pela maximização de eficiência.

Porém uma aproximação entre estes dois critérios apresenta-se como problemática. Ainda que o "bem comum" possa ser apontado como um topoi - isto é, um lugar comum de caráter persuasivo $0^{310}$-, de modo que um pensamento nele fundado não busca uma demonstração, justificando, eventualmente, uma certa abertura interpretativa, esta, contudo, não seria suficiente para fazer alusão à eficiência ${ }^{311}$.

Isto ocorre porque o critério da eficiência não apresenta um caráter generalizante capaz de satisfazer as condições de "bem comum" em abstrato, como se demonstrará abaixo. Deve-se destacar que tanto o critério de Kaldor-Hicks, quanto o critério proposto por Pareto não conseguem servir como mecanismo norteador da interpretação.

A eficiência entendida no sentido formulado por Kaldor e Hicks, que costuma ser o critério usualmente mais difundido entre os economistas, busca oferecer um critério para superar a necessidade de realizar comparações interpessoais ${ }^{312}$. Contudo, como este critério pressupõe somente uma possibilidade de compensação hipotética, isto é, como a compensação dos prejudicados pelos beneficiados por uma determinada medida não precisa necessariamente ocorrer, não há como se garantir que houve realmente um aumento no bem-estar (welfare), sem que uma comparação interpessoal seja efetivamente dispensada ${ }^{313}$. Caso o critério exigisse que a compensação de fato ocorresse, todos os envolvidos em uma transação - e os terceiros que por ela fossem afetados - estariam ao menos na situação igual à anterior, de modo que não haveria necessidade de fato de se realizar a comparação interpessoal.

Contudo, como isto não ocorre, um aumento no bem-estar geral só poderia ser verificado caso fosse pressuposto que cada pessoa valorasse um bem conforme outra o fizesse, ou, em outras palavras, que cada unidade monetária fosse valorada igualmente por

${ }^{310}$ FERRAZ JR., Tercio Sampaio. Introdução ao estudo do direito: técnica, decisão, dominação. 3. ed. São Paulo: Atlas, 2001, p. 322 e ss.

311 „Aus dem Blickwinkel der Rhetorik sehen die Topoi dagegen anders aus. Sie sind in der pragmatischen Sprachdimension verständlich zu machen. Sie eröffnen als pragmatische und situative Suchformeln ein kontrollierbares Kreationsspiel“" (VIEHWEG, Theodor. Rhetorik, Sprachpragmatik, Rechtstheorie, in: VIEHWEG, Theodor. Rechtsphilosophie und Rhetorische Rechtstheorie: gesammelte kleine Schriften. Baden-Baden: Nomos, 1995, p. 209).

${ }^{312}$ Vide acima item 3.1.1.

313 "The Kaldor-Hicks criterion is unscientific as the positivist defines the term. First, as a premise about the amount of satisfaction a dollar creates in one person or another, the Kaldor-Hicks criterion requires an interpersonal comparison of subjective welfare precisely like the one made by welfare economists. The fact that compensation is not actually paid under the Kaldor-Hicks criterion renders it impossible to conclude that a Kaldor-Hicks improvement is actually an improvement in welfare without such an assumption" (HOVENKAMP, Herbert. The first great law \& economics movement, in: Stanford Law Review, Vol. 42, $\mathrm{N}^{\circ}$ 4, abril de 1990, p. 1041). 
todos os indivíduos - o que se choca frontalmente com a idéia de utilidade marginal exposta anteriormente -, segundo a qual esta valoração tende a ser decrescente ${ }^{314}$. Esta postura de valorar a primeira unidade monetária igualmente à bilionésima unidade monetária é adotada pelo critério de Kaldor-Hicks, sem que, contudo, seja oferecida uma justificativa para este pressuposto ${ }^{315}$. Deste modo, o critério de Kaldor-Hicks não consegue cumprir sua principal meta, que era oferecimento de um instrumento capaz de valorar as transações independentemente de se realizar uma comparação interpessoal ${ }^{316}$.

Em relação ao critério de Pareto, além de ele ser difícil de verificar na prática, como já mencionado, uma vez que a maior parte das alterações sociais acabam tendo alguma forma de impacto negativo para algum indivíduo, o mesmo, ao contrário do que uma análise preliminar pode sugerir, não consegue apresentar uma fundamentação moral para um ordenamento jurídico. Quem oferece uma crítica, que demonstra uma falta de moralidade do critério paretiano, é o próprio Posner, desenvolvendo seu raciocínio por meio da explicação de dois exemplos.

No primeiro deles, supõe-se a existência de duas famílias, tendo cada uma delas um filho ${ }^{317}$. A primeira é uma família de poucas posses e o seu filho sofre de nanismo. Já a

${ }^{314}$ HOVENKAMP, Herbert. The first great law \& economics movement, in: Stanford Law Review, Vol. 42, $\mathrm{N}^{\circ} 4$, abril de 1990, p. 1041.

315 "The recommendations that flow from Kaldor's principle are sometimes different from the recommendations of the material welfare school. Suppose we are considering the desirability of a redistribution policy that raises marginal tax rates at low incomes and lowers marginal tax rates at high incomes. This policy is expected to raise the national income the increase accruing to the rich. Suppose further that their eventual gain in income exceeds the loss in the income of the poor. Using Kaldor's criterion, we would say that the policy results in an economic gain, even if the rich do not compensate the poor. However Pigou's criterion yields no definite result in this case. (Although it would agree with Kaldor's criterion if compensation were paid). Alternatively, if the eventual money gain to the rich were exactly equal to the loss of the poor, Kaldor's criterion would evaluate the two situation equally, whereas the original situation would dominate under Pigou's rules. The difference in conclusions occurs because Kaldor's approach requires the economist to proceed as if a dollar were equally valuable to everyone, whereas Pigou's requires the economist to proceed as if a dollar were more valuable to the poor than to the rich. Thus, Kaldor made a different conventional judgment from Pigou, rather than no judgment. However most subsequent discussion of compensation criteria did not consider this point. This suggest that a generation of economists was trained to believe that science treats a dollar as equally valuable to everyone, whereas a non-scientific approach treats a dollar as more valuable to the poor than to the rich" (COOTER, Robert; RAPPOPORT, Peter. Were the ordinalists wrong about welfare economics?, in: Journal of Economic Literature, Vol. 22, junho de 1984, p. 526 [grifo no original; nota de rodapé omitida]).

${ }^{316}$ HOVENKAMP, Herbert. The first great law \& economics movement, in: Stanford Law Review, Vol. 42, $\mathrm{N}^{\circ}$ 4, abril de 1990, p. 1042.

317 "Suppose that pituitary extract is in very short supply relative to the demand and is therefore very expensive. A poor family has a child who will be a dwarf if he doesn't get some of the extract, but the family cannot afford the price and could not even if it could borrow against the child's future earnings as a person of normal height, because the present value of those earnings net of consumption is less than the price of the extract. A rich family has a child who will grow to normal height, but the extract will add a few inches more and his parents decide to buy it for him. In the sense of value used in this book, the pituitary extract is more valuable to the rich family than to the poor one, because value is measured by willingness to pay; but the 
segunda é uma família abastada e que possui um filho que atingirá um tamanho considerado normal. Caso houvesse um extrato extremante raro que agisse sobre a glândula pituitária (hipófise), este extrato poderia atribuir ao filho que sofre de nanismo um tamanho considerado normal, enquanto o mesmo extrato só seria capaz de atribuir alguns poucos centímetros ao filho que possuía estatura padrão. Como a substância em questão é extremamente rara, seu preço acaba sendo elevado, de modo que a família menos abastada não o poderia comprar, enquanto a outra família poderia adquiri-lo sem maiores dificuldades. Neste cenário, o valor da substância é maior para a família mais abastada, já que o valor se refere à disposição de pagar (willingness to pay), ainda que seu efeito prático possa ser menor, caso seja adquirida por esta família e não pela outra, que poderia curar o nanismo de seu filho.

O segundo caso é uma espécie de variação deste. Nele supõe-se que um indíviduo A possui um artesanato de madeira, que ele avalia em cinquenta dólares, enquanto outro indivíduo, B, atribui ao mesmo objeto o valor de cento e vinte dólares. Assim, caso A venda o artefato para $\mathrm{B}$, esta transação pode gerar um benefício de setenta dólares - isto é, o preço de cem dólares pode gerar cinquenta dólares de benefício para A, enquanto B percebe um benefício de vinte dólares. Caso eventuais prejudicados por esta transação sob a condição de que seu prejuízo não seja superior a setenta dólares - fossem compensados, a mesma poderia satisfazer o critério de Pareto ${ }^{318}$. Todavia, é possível que a valoração que A e B fizeram do artefato de madeira não fosse fundada em sua preferência pelo mesmo, mas devido a outras condições. É possível que A adore sua peça de artesanato de madeira, mas seja obrigado a vendê-la porque está carente de recursos, de modo que precisa do dinheiro para poder se alimentar, enquanto que é possível que B não goste da mencionada peça, pretendendo apenas diversificar sua riqueza e para tanto comece a adquirir uma variedade de objetos colecionáveis. Deste modo, ainda que se encontre uma justificativa para a transação ocorrer, a mesma acaba por minar uma fundamentação moral para o critério de Pareto. O motivo para tanto seria o fato de o critério de Pareto não avaliar

extract would confer greater happiness in the hands of the poor family than in the hands of the rich one" (POSNER, Richard A.. Economic analysis of law. 7. ed. Nova Iorque: Aspen, 2007, p. 11).

318 "If A values the wood carving at $\$ 50$ and B at $\$ 120$, so that at any price between $\$ 50$ and $\$ 120$ the transaction creates a total benefit of $\$ 70$ (at a price of $\$ 100$, for example, A considers himself $\$ 50$ better off and B considers himself $\$ 20$ better off), it is an efficient transaction provided that the harm (if any) done to third parties (minus any benefit to them) does not exceed $\$ 70$. The transaction would not be Pareto superior unless A and B actually compensated the third parties for any harm suffered by them" (POSNER, Richard A.. Economic analysis of law. 7. ed. Nova Iorque: Aspen, 2007, p. 13). 
a distribuição de riqueza inicial, de modo que o critério de Pareto por si só não poderia servir como critério orientador ${ }^{319}$.

Deste modo, ainda que a análise econômica do direito tente explicar princípios jurídicos por meios econômicos ${ }^{320}$, o próprio Posner acaba por admitir que o critério econômico da eficiência não é suficiente para uma fundamentação da justiça, isto é, que outros critérios também devem ser levados em consideração, mesmo na vertente normativa da análise econômica do direito $^{321}$. Com efeito, haveria dificuldade para que um ordenamento jurídico, como o brasileiro, pudesse adotar o método proposto por Posner para a interpretação das leis e promover deste modo a eficiência como critério orientador. Isto não significa que o método de interpretação proposto por Posner não poderia ser aplicado para interpretar o ordenamento jurídico brasileiro, mas indica que o aludido método não seria adequado para utilizar a eficiência como critério norteador da aplicação judicial, o que é um dos objetivos da Escola de Chicago.

Em outras palavras, seguir primordialmente um método de interpretação voltado para a análise da vontade do legislador - isto é, um método subjetivo ${ }^{322}$-, como proposto por Posner, acaba por impedir que os objetivos defendidos pela análise econômica do direito sejam implementados por meio do processo interpretativo para qualquer ordenamento jurídico. A esta corrente, uma consideração de um elemento externo à vontade do legislador poderia em tese promover esta tarefa.

\footnotetext{
319 "Praticalities to one side, the dependence of Pareto superiority on the distribution of wealth - willingness to pay, and hence value, being a function of that distribution - further limits the normative adequacy of the efficiency criterion. A in our example may have valued the wood carving at only $\$ 70$ and B at $\$ 120$ not because A likes wood carvings less than B - he may like them much more - and not because there is any appealing concept of desert that B might invoke to validate his claim to be able to buy the wood carving; A may simple be destitute and have to sell his wood to carving in order to eat, while B, rather than being passionate about wood carvings, merely wants to diversify his wealth by holding a variety of collectibles. These circumstances (which make this a variant of the pituitary-extract case) are not inconsistent with the sale's making both A and B better off; on the contrary, they explain why it makes both better off. But the circumstances undermine the moral foundations of a social system oriented to Pareto superiority, let alone Pareto superiority. The general point is that the pattern of consumption and production is determined by the distribution of wealth, so that if that distribution is unjust, the pattern of economic activities derived from it will not have a strong claim to be regarded as just either. And insofar as the distribution of wealth is itself largely determined by the market, the justice of the market cannot be derived from some independent notion of the just distribution" (POSNER, Richard A.. Economic analysis of law. 7. ed. Nova Iorque: Aspen, 2007, p. 13 [grifo no original]).

320 "The idea of the rule of law originated in Aristotle's concept of 'corrective justice', a concept itself rich in economic significance" (POSNER, Richard A. Economic analysis of law. 7. ed. Nova Iorque: Aspen, 2007, p. 267).

321 "An effort will be made in this book to explain some of these prohibitions in economic terms, but many cannot be. Evidently there is more to justice than economics, and this is a point the reader should keep in mind evaluating normative statements in this book" (POSNER, Richard A. Economic analysis of law. 7. ed. Nova Iorque: Aspen, 2007, p. 27)

${ }^{322}$ FERRAZ JR., Tercio Sampaio. Introdução ao estudo do direito: técnica, decisão, dominação. 3. ed. São Paulo: Atlas, 2001, p. 262.
} 
Neste sentido, resta ainda a se analisar, se e como a eficiência pode se adeqüar ao modelo interpretativo anteriormente apresentado no presente trabalho ${ }^{323}$. De acordo com o modelo anteriormente proposto para a intepretação de um dispositivo normativo, além do signficado de base deve ser considerado o contexto lingüístico e o contexto de situação, não só do remetente, como também do destinatário.

Deste modo, como no método interpretativo proposto por Posner, a análise do debate legislativo é importante para este modelo de interpretação, pois ajuda a compor uma análise do contexto de situação do remetente. Assim, o significado de base das palavras deve ser lido não só no contexto lingüístico - o que pode ocorrer por meio de outras disposições, por exemplo, as que apresentam função metalingüística, como as definições e redefinições legislativas -, mas também o contexto de situação. Dando destaque para esta análise do contexto, pode-se buscar então indícios de uma busca do ordenamento jurídico pela eficiência.

Neste sentido, no ordenamento jurídico brasileiro, desde a Emenda Constitucional 19 de 4 de junho de 1998, há a enunciação expressa no Art. 37 da Constituição Federal ${ }^{324}$ de que a administração pública deve se pautar pelo "princípio da eficiência". Entretanto, este princípio não costuma ser entendido no sentido de fazer referência ao critério de Pareto ou ao critério de Kaldor-Hicks. Seu entendimento costuma se dar no sentido de que a administração pública deve buscar o "melhor desempenho" de suas atribuições, para que o agente público atinja os melhores resultados e para que o serviço público seja prestado também com os melhores resultados ${ }^{325}$, isto é, que a atividade administrativa seja pautada pelo resultado ${ }^{326}$. Destaque-se que, mesmo em relação a esta forma de entendimento da eficiência, a doutrina também percebe que poderia haver um choque com o princípio da legalidade, devendo este último ser resguardado ${ }^{327}$.

Como o dispositivo trata de todos os Poderes em todos as esferas administrativas - União, Estados e Municípios -, o Poder Judiciário certamente estaria incluso e ainda pode-se depreender que a atuação dos magistrados deve se dar de um modo a garantir que a prestação jurisdicional seja eficiente, ou como entendido pela doutrina, que apresenta os

\footnotetext{
${ }^{323}$ Vide o item 4.2 e ss.

324 “Art. 37. A administração pública direta e indireta de qualquer dos Poderes da União, dos Estados, do Distrito Federal e dos Municípios obedecerá aos princípios de legalidade, impessoalidade, moralidade, publicidade e eficiência e, também, ao seguinte (...)" (nosso grifo).

${ }^{325}$ DI PIETRO, Maria Sylvia Zanella. Direito administrativo. 15. ed. São Paulo: Atlas, 2003, p. 83.

${ }^{326}$ FERRAZ JR., Tercio Sampaio. Princípio da eficiência, in: FERRAZ JR., Tercio Sampaio. Direito Constitucional: liberdade de fumar, privacidade, Estado, direitos humanos e outros temas. Barueri: Manole, 2007, p. 379.

${ }^{327}$ DI PIETRO, Maria Sylvia Zanella. Direito administrativo. 15. ed. São Paulo: Atlas, 2003, p. 84.
} 
melhores resultados. Contudo, ainda que a atividade jurisdicional deva ser eficiente, desta assertiva não se pode deduzir que cada decisão por si só deva promover a eficiência segundo o critério de Pareto ou o de Kaldor-Hicks.

Com efeito, a principal menção expressa no ordenamento jurídico brasileiro ao princípio da eficiência não faz menção aos referidos critérios. Neste sentido, pode-se afirmar que o siginificado de base e o contexto lingüístico do ordenamento jurídico brasileiro não permitem uma interpretação judicial que desenvolva os pârametros de uma análise econômica do direito segundo a visão da Escola de Chicago. Resta, pois, analisar se o mesmo pode ser depreendido de um contexto de situação do remetente ou do destinatário.

Para a análise do contexto de situação do remetente, convém analisar a origem do dispositivo que trata do princípio da eficiência, que foi inserido pela Emenda Constitucional 19 de 4 de junho de 1998. A origem desta Emenda foi a Proposta de Emenda à Constituição 173 de 23 de agosto de 1995, que foi apresentada pelo Poder Executivo. Para o processo de elaboração desta, é esclarecedora a Exposição de Motivos Interministerial $\mathrm{N}^{\circ} 49$ de 18 de Agosto de 1995. Neste documento, preparado pelos Ministros da Justiça, da Fazenda, da Previdência e Assistência Social, da Educação e do Desporto, da Administração Federal e Reforma do Estado e do Planejamento e do Orçamento, há o esclarecimento de que a adoção do princípio da eficiência deverá aprimorar o aparelho do Estado, que deveria trazer mais benefícios aos cidadãos na utilização dos recursos disponíveis ${ }^{328}$.

Deste modo, ainda que o dispositivo esteja ligado a uma análise da aplicação de recursos escassos, os elementos disponíveis do contexto de situação do remetente indicam que o referido dispositivo não se relaciona a uma aplicação dos critérios de Pareto ou de Kaldor-Hicks, como anteriormente já havia sido apontado ao se referir que o método de reconstrução das intenções do legislador não permitiria promover uma generalização interpretativa do método de eficiência. Com efeito, restaria como alternativa uma análise

\footnotetext{
328 “Acreditamos que as Emendas Constitucionais ora apresentadas venham a contribuir decisivamente para o revigoramento da administração pública, com impactos positivos sobre o conjunto da ação governamental e sobre a sociedade. Como resultados esperados da reforma administrativa, vale destacar o seguinte:

- incorporar a dimensão da eficiência na administração pública: o aparelho do Estado deverá se revelar apto a gerar mais benefícios na forma de prestação de serviços à sociedade com os recursos disponíveis em respeito ao cidadão contribuinte"

(Exposição de Motivos Interministerial Nº 49 de 18 de Agosto de 1995, in: Diário do Congresso Nacional de 18 de Agosto de 1995 [grifo no original], disponível em http://imagem.camara.gov.br/dc_20.asp?selCodColecaoCsv=D\&Datain=18/8/1995\&txpagina=18849\&altura $=700 \&$ largura $=800$, último acesso em 9 de janeiro de 2010).
} 
do contexto de situação do destinatário, como forma de tentar promover a vertente normativa da análise econômica do direito na visão da Escola de Chicago. Contudo, é de se relembrar que os limites deste método interpretativo já diferem dos delineados no método de Posner.

Dando seguimento à pesquisa com a análise do contexto de situação do destinatário, é de ser destacado que esta normalmente faz referência a uma alteração das condições sócio-econômicas que existiam quando da emissão da mensagem normativa, em relação às vigentes quando de seu recebimento. No caso em tela não se trata de uma alteração das condições sócio-econômicas, podendo no máximo ser uma alteração das concepções vigentes, o que também poderia ter impactos profundos no funcionamento do ordenamento jurídico.

Um exemplo que ilustra esta situação - ainda que também seja apoiado por alterações nas condições sócio-econômicos - é fornecido por Weber. Segundo este autor, um ordenamento jurídico fundado na propriedade e na liberdade contratual poderia teoricamente passar a orientar uma ordem de produção socialista, desde que uma estatização dos meios de produção se desse por meio de contratos concluídos livremente $^{329}$. Ainda que como o próprio autor do exemplo reconheça que este exemplo seria extremamente improvável de se verificar na prática, o exemplo mostra que uma alteração das concepções a respeito da orientação da economia poderia alterar o modo como que os institutos jurídicos passassem a ser praticados.

Todavia, para que a referida situação ocorresse, deveria ser passível de se verificar que as concepções atuais convergissem para o proposto pela vertente normativa da Escola de Chicago, o que é um critério que não se verifica na prática. Deste modo, uma reorientação do ordenamento jurídico seguindo os preceitos da Escola de Chicago não pode ocorrer, sem que haja uma brutal alteração nos preceitos que regulam a interpretação judicial no ordenamento jurídico.

\footnotetext{
329 „Eine Rechtsordnung kann unter Umständen unverändert bestehen bleiben, obwohl die Wirtschaftsbeziehungen sich radikal ändern. Theoretisch - und in der Theorie operiert man zweckmäßig mit extremen Beispiele - könnte ohne die Aenderung auch nur eines einzigen Paragraphen unserer Gesetze eine , sozialistische' Produktionsordnung durchgeführt werden, wenn man einen sukzessiven Erwerb der Produktionsmittel durch die politische Gewalt im Wege freier Verträge sich durchgeführt denkt, - ein gewiß höchst unwahrscheinlicher, aber (was theoretisch genügt) keineswegs sinnloser gedankt. Die Rechtsordnung würde dann mit ihrem Zwangsapparat nach wie vor bereitstehen müssen für den Fall, dass zur Erzwingung den für die privatwirtschaftliche Produktionsordnung charakteristischen Verpflichtungen ihre Hilfe angerufen würde. Nur würde dieser Fall tatsächlich nie eintreten“ (WEBER, Max. Wirtschaft und Gesellschaft: Grundriss der verstehenden Soziologie. 5. ed. Tübingen: Mohr Siebeck, 1980, p. 196).
} 
Apesar de o aspecto normativo da análise econômica do direito não poder fornecer um critério central para a interpretação judicial, outros elementos da teoria proposta pela Escola de Chicago podem ser úteis na aplicação do direito. Assim, a seguir passa-se a analisar como isto pode ocorrer.

\subsection{Dircurso jurídico diante do discurso econômico}

Para entender esta relação entre o discurso jurídico e o discurso econômico, convém retomar alguns pontos da análise desenvolvida até aqui. Como visto, no início do século XX Stammler propunha que o direito seria apenas um instrumento humano que deveria se adequar às condições econômicas, que apresentariam uma força natural ${ }^{330}$. Este pensamento a respeito da naturalidade da economia, como aponta Irti, também é compartilhado pelos que defendem um liberalismo econômico extremado ${ }^{331}$.

Mesmo postulando esta naturalidade do fenômeno econômico, estas duas correntes extremadas apontam que o direito pode servir de barreira ao desenvolvimento econômico, o que justificaria sua mudança ${ }^{332}$. Caso esta naturalidade da economia se verificasse, a alteração do direito não seria necessária, pois não teria efeito algum na economia, como aconteceria com os fenômenos naturais - por exemplo, se o direito postulasse que dois corpos não mais se atraíssem, o magnetismo entre os corpos continuaria existindo.

Desta maneira percebe-se que o direito pode interferir na economia, de modo que o discurso jurídico não é totalmente condicionado pelo discurso econômico. Entretanto, não seria correto afirmar que o discurso jurídico predomina sobre o discurso econômico, uma vez que o direito não é onipotente, isto é, o direito também está sujeito a condicionantes sócio-econômicas ${ }^{333}$. Desta forma, pode-se destacar que em determinadas situações há um entrelaçamento entre estas duas formas de discurso.

\footnotetext{
330 „Die ökonomischen Phänomene sind, nach dieser Lehre, von Natur; - die rechtliche Regelung aber ist ein daneben Hülfsmittel der Menschen“ (STAMMLER, Rudolf. Wirtschaft und Recht nach der materialistischen Geschichtsauffassung: eine sozialphilosophische Untersuchung. 2. ed. Leipzig: Veit, 1906, p. 43).

${ }^{331}$ IRTI, Natalino. A ordem jurídica do mercado, in: Revista de Direito Mercantil, industrial, econômico e financeiro (RDM), Vol. 46, $\mathrm{N}^{\circ} 145$, janeiro-março de 2007, p. 44.

${ }^{332}$ STAMMLER, Rudolf. Wirtschaft und Recht nach der materialistischen Geschichtsauffassung: eine sozialphilosophische Untersuchung. 2. ed. Leipzig: Veit, 1906, p. 45; IRTI, Natalino. A ordem jurídica do mercado, in: Revista de Direito Mercantil, industrial, econômico e financeiro (RDM), Vol. 46, $\mathrm{N}^{\circ} 145$, janeiro-março de 2007, p. 46.

333 "Law is but a part of social and cultural engineering. Today the questions about the limits of legislative action, about its relation to political force and economic efficiency, about its ability to create new types of man and new types of culture, are as practically cogent as they are theoretically illuminating"
} 
Uma destas formas de entrelaçamento é apontada por Ferraz Jr.. Apoiando-se em Weber, Ferraz Jr. acaba por diferenciar uma interpretação de bloqueio - que corresponderia à hermenêutica tradicional - da interpretação de legitimação, que seria menos atenta ao formalismo tradicional ${ }^{334}$. Segundo nosso entendimento, esta possibilidade de interpretação poderia ser desenvolvida considerando uma análise do contexto de situação do remetente e do destinatário.

Esta interpretação, que considera os dois contextos de situação, pode promover uma atualização do direito ${ }^{335}$. Um exemplo disso ocorreria quando uma mensagem normativa, que em um determinado contexto era entendida como sendo expressão de função conativa - como tratado em capítulo anterior -, passa em outro contexto a ser entendida como função fática. E o inverso também pode vir a ocorrer, o que seria demonstrado pelo caso do salário mínimo: atualmente as condições sócio-econômicas do Brasil não permitem que o dispositivo constitucional que determina os padrões para o salário mínimo (Art. $7^{\circ}$, IV da Constituição Federal) seja entendido como função conativa, mas no futuro isto pode vir a ocorrer, sem que haja uma alteração do texto normativo.

Contudo, esta interpretação que adota uma postura menos formal deve ficar atenta a um requisito presente no contexto - lingüístico (se expresso) ou de situação: o direito deve promover a decidibilidade dos conflitos com um mínimo de perturbação social, como visto anteriormente. Para tanto, é necessário que o direito consiga servir como orientador das condutas sociais, o que pressupõe uma certa estabilidade e uma certa previsibilidade, de modo a resguardar um mínimo de segurança jurídica. Isto é, ainda que a interpretação não observe uma formalidade estrita, alguma espécie de limite será inerente a ela, para que assim possa satisfazer o mencionado papel do direito.

Desse modo, quando a interpretação se distanciar do significado de base e do contexto lingüístico de um texto normativo, ela deverá apresentar uma justificativa mais minuciosa para tanto. Com efeito, o controle da racionalidade da decisão poderá ser feito por esta argumentação, garantindo um mínimo de previsibilidade das decisões. Sendo esta garantida, um mínimo de estabilidade também estará assegurado, pois uma alteração do entendimento normativo por meio de uma interpretação que altere a atribuição de uma

(MALINOWSKI, Bronislaw. A new instrument for the interpretation of law - especially primitive, in: The Yale Law Journal, Vol. 51, 1941-1942, p. 1247).

${ }^{334}$ FERRAZ JR., Tercio Sampaio. Hermenêutica constitucional: interpretação de bloqueio e de legitimação, in: FERRAZ JR., Tercio Sampaio. Direito Constitucional: liberdade de fumar, privacidade, Estado, direitos humanos e outros temas. Barueri: Manole, 2007, p. 14 e ss.

${ }^{335}$ GRAU, Eros Roberto. Ensaio e discurso sobre a interpretação/aplicação do direito. 2. ed. São Paulo: Malheiros, 2003, p. 110. 
determinada função da linguagem a um dispositivo, só se verificará, caso haja uma profunda alteração do contexto de situação, que possa embasar uma justificativa racional para tanto.

Exposto o entrelaçamento entre o discurso jurídico e o discurso econômico na interpretação em geral, pode-se passar para o estudo de outro ponto, que ajuda a entender a diferença entre o discurso jurídico e o econômico. Trata-se da questão de a análise econômica, bem como seu discurso, normalmente ser mais prognóstica, enquanto que o enfoque jurídico tradicional ser mais retrospectivo.

Este enfoque jurídico tradicional se relaciona com a visão de o direito ser caracterizado pela sanção, que seria imputada, uma vez que hipótese de incidência normativa fosse verificada. Ora esta análise da verificação da hipótese de incidência de uma determinada norma é uma análise tipicamente preocupada com os acontecimentos passados, isto é, retrospectiva.

De maneira contrária, quando o Estado não mais apenas garante a segurança, mas também passa a oferecer prestações positivas, outro tipo de análise se faz necessário. Para apurar qual é o salário mínimo adeqüado a ser fixado, qual o depósito compulsório que os bancos deverão efetuar ou mesmo qual a taxa de juros a ser fixada, a mera reconstrução do passado não é suficiente. Não que ela não seja importante, mas ela não é a única necessária, como acontecia no caso de aplicação da sanção para um delito.

Deste modo, o operador do direito se vê diante de uma necessidade de efetuar uma análise prognóstica, para qual o instrumentário da análise econômica pode se mostrar proveitoso. Neste sentido a análise interdisciplinar surge como tentativa de que um campo do conhecimento ofereça respostas para as questões que são colocadas por outra área do conhecimento $^{336}$.

Anteriormente, os próprios economistas reconheciam que o seu desenvolvimento teórico ainda estava longe de oferecer um conjunto de ferramentas que permitisse realizar previsões com uma margem de segurança ${ }^{337}$. Entretanto, atualmente há quem defenda que

336 „Der methodische Grund für die Forderung nach interdisziplinärer Forschung liegt darin, daß jede Wissenschaft Fragen produziert, die sie selber nicht beantworten kann, von denen sie aber hofft, daß andere Wissenschaften sie beantworten können, die sie selber nicht stellen“ (NOLL, Peter. Gesetzgebungslehre. Reinbek bei Hamburg: Rowohlt, 1973, pp. 64-65).

337 "It is in their fundamental aspect as an organon of laws, and not in their superficial aspect as a description of facts, that the realistic sciences have bearing upon the conduct of affairs. The establishment of such an organon adapted and ready for application to particular problems is the ideal at which they aim.

To say this without saying something more would, however, be very misleading. It is not pretended that, at the present stage of its development, economic science is able to provide an organon even remotely approaching to what it imagines for itself as ideal" (PIGOU, A. C.. The economics of welfare. 4. ed. Londres: Macmillan, 1952, p. 8). 
a teoria econômica venha se aproximando deste ideal, como Posner, que sustenta que a teoria econômica tem se mostrado capaz de prever acontecimentos e também promover intervenções efetivas, ainda que o faça com menos sucesso do que, por exemplo, a física $^{338}$.

De todo modo, é reconhecido que a análise econômica ainda é incapaz de fornecer uma resposta única para diversas questões que são colocadas pelo direito. Mesmo em relação ao direito concorrencial, a área em que a análise econômica apresenta maior tradição, como já acima apontado, pode não se verificar a "análise econômica", mas “análises econômicas" - no plural, que podem até mesmo ser conflitantes ${ }^{339}$. Isto ocorreria, porque a teoria econômica ainda se apresenta em constante desenvolvimento e também porque ainda não há um consenso a respeito de muitas conclusões ${ }^{340}$.

Ademais, deve-se destacar que a transposição da análise econômica para instituições econômicas apresenta outro tipo de limitações. Gerber aponta que a análise econômica está sujeita a diferentes limitações institucionais e de procedimento, que moldam a maneira de influência desta forma de análise ${ }^{341}$. Antes de explicitar como as

\footnotetext{
338 "An important test of a theory is its ability to explain reality. If it does a lousy job, the reason may be that assumptions are insufficiently realistic. But we need no try to evaluate the assumptions directly in order to evaluate it. Judged by the test of explanatory power, economic theory is a significant (although only partial) success; so perhaps the assumption that people are rational maximizers of their satisfactions is not so unrealistic as the noneconomist might at first think. (...)

Another (and stronger-why?) test of a scientific theory is its predictive power. Here, too, economics has had its share of success, most dramatically in recent decades. (...)

Still another test of a scientific theory is its ability to underwrite effective interventions in the world of action. The most dramatic example is the atomic bomb, which showed that modern atomic theory was no just another clever speculation about invisible entities. In this respect, too, economics has had successes, albeit more modest ones than the natural sciences have had. (...). These interventions have worked, suggesting that economic theory is more than just pretty math." (POSNER, Richard A. Economic analysis of law. 7. ed. Nova Iorque: Aspen, 2007, p. 16).

339 "Um aspecto diferenciador do presente livro em relação em relação ao de Kwoka e White, foi o fato de aqui haver artigos com visões opostas sobre os mesmos casos com o objetivo de apresentar, com base na boa teoria econômica, perspectivas diferentes sobre o mesmo objeto, o que reafirma o entendimento de que, assim como em outras matérias, não há uma fórmula rígida e pré-concebida para o antitruste" (MATTOS, César. Introdução, in: MATTOS, César (Org.). A revolução do antitruste no Brasil: a teoria econômica aplicada a casos concretos. São Paulo: Singular, 2003, p. 21).

340 "Although the specific limitations of various economic approaches are best left until the substantive topics are addressed, there are four noteworthy limits on the use of economics in antitrust analysis: (1) economic learning is an evolving and incomplete source, in part because the target of this study - the economy - is itself an everchanging phenomenon; (2) many conclusions even by leading economists are not a matter of consensus and some are highly controverted; (3) two of the most basic models of neo-classical economic analysis - the model of monopoly and the model of perfect competition - are based upon assumptions that are never fully met in real life markets; and (4) the assumptions that underlie economic analysis are often difficult or impossible to prove in an agency investigation or litigated case" (SULLIVAN, Lawrence A.; GRIMES, Warren S.. The law of antitrust: an integrated handbook. 2. ed. St. Paul: Thomson West, 2006, p.
} 20).

${ }^{341}$ GERBER, David J.. Competition law and the institutional embeddedness of economics, in: DREXL, Josef; IDOT, Laurence; MONÉGER, Joël. Economic theory and competition law. Cheltenham: Elgar, 2009, pp. 21-22. 
limitações institucionais e procedimentais operam, é importante destacar que, no direito concorrencial, elas acabam por interferir tanto na influência dos dispositivos normativos pela análise econômica - isto é, quando os conceitos econômicos são incorporados como padrão pelo ordenamento jurídico ${ }^{342}$-, quanto na influência da aplicação do método econômico para se apurar questões de fato - por exemplo, a aferição de poder de $\operatorname{mercado}^{343}$.

Tendo em mente estas duas dimensões da influência da economia no direito, Gerber afirma as instituições podem influenciar como o ordenamento jurídico recepcionára os conceitos econômicos, dado que, de acordo com o tipo de sistema jurídico, pode ser que o Judiciário tenha maior liberdade para definir esta questão, enquanto em outros sistemas isto dependerá de uma lei ${ }^{344}$. Já a aplicação do instrumentário econômico para a apuração de fatos pode ser sensível a questões de procedimento, como ocorreria ao se determinar qual a quantidade de dados a respeito de um caso que estará disponível, qual o acesso e a quem será dado acesso a estes dados, além de se enfatizar quais são os elementos que devem ser destacados a respeito dos dados levantados ${ }^{345}$. Assim, uma comparação entre os processos no sistema dos Estados Unidos e no sistema continental europeu, mostra que os advogados têm maior liberdade de produção de provas no primeiro, enquanto que no segundo o juiz acaba por exercer um maior controle a respeito de quais testemunhas serão ouvidas, quais perguntas serão feitas a ela, etc ${ }^{346}$. Deste modo, as instituições e os procedimentos acabam por condicionar a transposição dos conceitos econômicos, que

\footnotetext{
342 "Concepts and categories drawn from economic science - such as, for example, 'efficiency' -become operative standards of the legal system. This requires some mechanism for relating the economics concepts and language to those of the legal system. In effect, it requires that the economics be grafted onto the authoritative legal-political basis for decisions in the competition-law system" (GERBER, David J.. Competition law and the institutional embeddedness of economics, in: DREXL, Josef; IDOT, Laurence; MONÉGER, Joël. Economic theory and competition law. Cheltenham: Elgar, 2009, p. 25).

${ }^{343}$ GERBER, David J.. Competition law and the institutional embeddedness of economics, in: DREXL, Josef; IDOT, Laurence; MONÉGER, Joël. Economic theory and competition law. Cheltenham: Elgar, 2009, p. 25.

344 GERBER, David J.. Competition law and the institutional embeddedness of economics, in: DREXL, Josef; IDOT, Laurence; MONÉGER, Joël. Economic theory and competition law. Cheltenham: Elgar, 2009, pp. $25-26$.

345 GERBER, David J.. Competition law and the institutional embeddedness of economics, in: DREXL, Josef; IDOT, Laurence; MONÉGER, Joël. Economic theory and competition law. Cheltenham: Elgar, 2009, p. 26.

${ }^{346}$ GERBER, David J.. Competition law and the institutional embeddedness of economics, in: DREXL, Josef; IDOT, Laurence; MONÉGER, Joël. Economic theory and competition law. Cheltenham: Elgar, 2009, p. 34.
} 
neste sentido, quando aplicados por operadores do direito acabam por ganhar um contorno diferente daquele que os economistas atribuem a eles ${ }^{347}$.

Em relação à segunda dimensão mencionada, cabe notar que o emprego do método econômico para auxiliar na aferição de um fato se enquadra na categoria de utilização pelo direito dos préstimos de outras áreas do conhecimento. Destaque-se que o conhecimento técnico é expressamente mencionado como uma das formas de apreciação das provas ${ }^{348}$, mas o magistrado não está vinculado a uma conclusão técnica. Um exemplo disso ocorreria quando um teste de paternidade apontasse o vínculo biológico entre duas pessoas e mesmo diante disso o magistrado rejeitasse o reconhecimento de um vínculo jurídico de parentesco, caso o pai biológico tivesse doado esperma para um banco de sêmen. Isto é, mesmo que tecnicamente seja apurado um determinado fato, o magistrado ainda pode fazer uma análise valorativa do mesmo. No caso do método econômico, os dados que por meio dele vierem a ser apurados, também podem ser valorados pelo direito, de modo que a decisão jurídica não necessariamente coincidirá com a econômica.

De maneira mais complexa, quando os critérios econômicos se misturam com os jurídicos, as alterações no entendimento da teoria econômica acabam conduzindo a alterações no ordenamento jurídico. Como esta dimensão da interrelação entre direito e economia também está sujeita a influências institucionais e procedimentais, estas também podem conduzir a alterações no direito, conforme apontado pelo modelo hermenêutico que considera o contexto de situação do remetente e do destinatário. Contudo, como anteriormente apontado, as alterações normativas relacionadas à mudança no contexto de situação do destinatário devem ser conduzidas com cautela, sob pena de sacrificar a própria pacificação social objetivada pelo direito.

\footnotetext{
347 GERBER, David J.. Competition law and the institutional embeddedness of economics, in: DREXL, Josef; IDOT, Laurence; MONÉGER, Joël. Economic theory and competition law. Cheltenham: Elgar, 2009, p. 43.

${ }^{348}$ Art. 335 do Código de Processo Civil: "Em falta de normas jurídicas particulares, o juiz aplicará as regras de experiência comum subministradas pela observação do que ordinariamente acontece e ainda as regras da experiência técnica, ressalvado, quanto a esta, o exame pericial".
} 


\section{CONCLUSÃO}

O entendimento a respeito da relação entre o direito e a economia foi se alterando, como exposto ao longo do presente trabalho, de acordo não só pelos desenvolvimentos puramente teóricos, mas também pela orientação política, dos envolvidos no debate, a respeito da economia, bem como a respeito do papel do direito. Anteriormente o debate envolvia as premissas básicas da teoria econômica, e era corrente o entendimento de que o objeto da economia seria a riqueza e não a escassez.

Neste contexto, postulava-se até mesmo a alteração do modo de aquisição de bens, que era marcado pela propriedade privada. Alternativamente, pleiteava-se que a teoria econômica deveria pautar a diminuição das desiguladades sociais, o que ocorreria por meio da redistribuição de riqueza a ser operada principalmente pela tributação, além de se instituir padrões de segurança para o trabalhador, que também teria seus interesses protegidos pela introdução de um salário mínimo.

Contudo, as bases científicas desta teoria passam a ser questionadas, limitando-se o papel que a utilidade marginal - que se pautava em comparações interpessoais de preferências - poderia ter no debate, o que naquele momento também se mostrava conveniente, dado que assim uma orientação socialista poderia ser refutada. Esta nova concepção a respeito da teoria econômica acaba por estabelecer que o seu objeto central seria a escassez de recursos disponíveis, que deveria orientar o comportamento humano, o que passa a gozar de consenso entre os economistas.

Desse modo, postula a teoria econômica, que os arranjos que maximizem a eficiência devem ser buscados, sendo a eficiência entendida preferencialmente de acordo com o critério desenvolvido por Kaldor e por Hicks e não mais exclusivamente segundo o critério de Pareto. Entretanto, como já apontado, este critério não consegue superar por completo a dificuldade que resulta da comparação interpessoal de preferências.

Estas alterações na teoria econômica acabam por ter impacto no direito, cuja função já havia sofrido alteração: de mero garantidor da segurança por meio da imposição de sanções, o direito passa a promotor de organização social e implementador de políticas públicas. Assim, no desenvolvimento desta nova função, e com fundamento no primeiro entendimento exposto a respeito da economia, inicialmente se entendia que o direito deveria disciplinar a distribuição de riqueza, o que se daria por meio da tributação, mas 
também por meio daquela proteção ao trabalhador, além de haver a promoção de educação, saúde, etc, como já exposto.

Entretanto, na reorientação promovida pelo novo papel do direito, a atuação estatal deve se restringir ao mínimo, garantindo a liberdade dos indíviduos e empresas. A garantia da liberdade se torna uma questão central, dado que, de acordo com esta concepção, as transações consentidas representam a principal forma de promoção de maximização da eficiência, de forma que, maximizando-se a garantia da liberdade, também estará se garantindo a maximização da eficiência. Neste sentido, o papel do direito também envolvia a proteção da liberdade, para a qual seria um requisito a intervenção mínima do Estado.

Neste contexto, ganha destaque o papel do direito concorrencial, campo do direito em que a interrelação com a economia se apresenta mais próxima. Aliás, é nos Estados Unidos, e justamente nesta área do direito, que a Escola de Chicago alcança maior repercussão. A consolidação desta teoria no direito concorrencial norte-americano se dá de tal maneira, que alguns teóricos, principalmente da economia, passam a defender que as bases teóricas do direito concorrencial norte-americano - como a comprovação de prejuízo ao consumidor como requisito para a imposição de sanções por abuso de posição dominante - deveriam ser exportadas para outros lugares.

O debate na União Européia - ainda não completamente acabado - a respeito de uma reorientação do direito concorrencial, que passaria a seguir o direito norte-americano, mostra a dificuldade para se transpor os conceitos da teoria econômica para o ordenamento jurídico, uma vez que nesta situação os resultados produzidos pelaa teoria econômica são influenciados por diversos elementos do ordenamento jurídico. Nesta reorientação do direito concorrencial, o recurso a um dispositivo que condicione à licitude de um contrato a eventos que podem acontecer anos após a elaboração do contrato, parece não ser adeqüado a um ordenamento que pretenda orientar os comportamentos dos indivíduos. Neste sentido, ainda que possa ser adeqüado à teoria econômica, um dispositivo como o apontado, que deixe em suspenso a verificação de licitude de determinado contrato, tende a ser conflitante com o princípio da segurança jurídica.

Outra forma de relacionamento entre o direito e a economia, que pode vir a se chocar com o princípio da segurança jurídica seria uma interpretação, com base em critérios econômicos, que buscasse reorientar bruscamente uma determinada norma. Apesar desta ser depreendida somente a partir de uma interpretação, não é qualquer interpretação de um texto normativo que pode conformar adequadamente uma determinada 
norma. Assim, no modelo interpretativo proposto, não só o significado de base e o contexto lingüístico são considerados, mas outros elementos, como o contexto de situação do remetente e do destinatário também são considerados. Justamente para não se chocar com o princípio da segurança jurídica, a análise do contexto de situação deve ser conduzida de maneira cautelosa e deve apresentar uma justificativa, por meio da qual a racionalidade da interpretação fique clara.

Desse modo, uma interpretação judicial que busque introduzir os critérios de eficiência, postulados pela Escola de Chicago, pode vir a se chocar com os limites impostos pela racionalidade da interpretação. Isto não significa que instrumentos de microeconomia não possam ser utilizados para se delimitar um mercado relevante, para a aferição de poder de mercado ou até mesmo para o cálculo de indenizações.

Entretanto, uma interpretação voltada principalmente à busca de uma maximização da eficiência segundo o critério de Kaldor-Hicks, tende a não ser adequada para se interpretar um dispositivo do ordenamento jurídico que tenha o objetivo de conduzir a uma redistribuição de renda. Caso estes dispositivos venham a ser considerados ultrapassados, sua alteração deve vir a ocorrer por meio de lei.

Para a alteração do dispositivo em questão, e por ocasião do processo legislativo, não será apenas possível, mas também desejável, que se produza um estudo econômico a respeito das consequiências da alteração do mesmo. Para que o novo dispositivo possa a vir a ser institucionalizado, será necessário que estes resultados econômicos não sejam considerados isoladamente, mas em conjunto com outros critérios e valores, de modo a se aferir se o dispositivo proposto pode servir à decidibilidade dos conflitos com um mínimo de perturbação social. Deste modo, o direito poderá ser um instrumento da sociedade e não só um mero instrumento da economia. 


\section{REFERÊNCIAS BIBLIOGRÁFICAS}

ALEXY, Robert. Theorie der Grundrechte. Suhrkamp: Baden-Baden, 1994;

BOGDANDY, Armin von; BAST, Jürgen. Europäisches Verfassungsrecht: theorethische und dogmatische Grundzüge. 2. ed. Dordrecht: Springer, 2009;

BORK, Robert H.. A time to speak: selected writings and arguments. Wilmington: ISI Books, 2008;

BORK, Robert H.. The Constitution, original intent and economic rights, in: BORK, Robert H.. A time to speak: selected writings and arguments. Wilmington: ISI Books, 2008, pp. 260-269;

BÜHLER, Karl. Teoría del lenguaje. Madrid: Revista de Occidente, 1950. Também o original em alemão: BÜHLER, Karl. Sprachtheorie. 3.ed. Stuttgart: Lucius \& Lucius, 1999;

CALABRESI, Guido. Thoughts on Risk Distribution and the Law of Torts, in: The Yale Law Journal, Vol. 70, № 4, março de 1961, pp. 499-553;

CANOTILHO, José Joaquim Gomes. Constituição dirigente e vinculação do legislador: contributo para a compreensão das normas constitucionais programáticas. 2.ed. Coimbra: Coimbra, 2001;

CARRIÓ, Genaro R. Notas sobre derecho y lenguaje. 4. ed. Buenos Aires: Abeledo Perrot, 1994;

CASE, Karl E.; FAIR, Ray C.. Principles of economics. 7. ed. Nova Jersey: Pearson, 2004;

COASE, R. H.. The problem of social cost, in: Journal of Law and Economics, Vol. 3, Outubro de 1960, pp. 1-44;

COOTER, Robert; RAPPOPORT, Peter. Were the ordinalists wrong about welfare economics?, in: Journal of Economic Literature, Vol. 22, junho de 1984, p. 507530 ;

COOTER, Robert; ULEN, Thomas. Law and economics. 2. ed. Reading: Addison-Wesley, 1997;

DI PIETRO, Maria Sylvia Zanella. Direito administrativo. 15. ed. São Paulo: Atlas, 2003;

DREHER, Meinrad. Die Zukunft der Missbrauchsaufsicht in einem ökonomisierten Kartellrecht, in: Wirtschaft und Wettbewerb [WuW], Vol. 58, N 1 , janeiro de 2008, pp. 23-27; 
DREHER; Meinrad; ADAM, Michael. The more economic approach to Art. 82 EC and the legal process, in: Zeitschrift für Wettbewerbsrecht (ZWeR), Vol. 4, N³, 2006, pp. 259-277;

DREXL, Josef. Die neue Gruppenfreistellungsverordnung über TechnologietransferVereinbarungen im Spannungsfeld von Ökonomisierung und Rechtssicherheit, in: Gewerblicher Rechtsschutz und Urheberrecht Internationaler Teil, Vol. 53, № 9, setembro de 2003, pp. 716-727;

DREXL, Josef. Wettbewerbsverfassung, in: BOGDANDY, Armin von; BAST, Jürgen. Europäisches Verfassungsrecht: theorethische und dogmatische Grundzüge. 2. ed. Dordrecht: Springer, 2009;

DREXL, Josef; IDOT, Laurence; MONÉGER, Joël. Economic theory and competition law. Cheltenham: Elgar, 2009;

DWORKIN, Ronald. Law's empire. Cambridge: Harvard, 1986;

EILMANBERGER, Thomas. Verbraucherwohlfahrt, Effizienzen und ökonomische Analyse - neue Paradigmen im europäischen Kartellrecht?, in: Zeitschrift für Wettbewerbsrecht (ZWeR), Vol. 4, N4, 2009, pp. 437-471;

EMMERICH, Volker. Kartellrecht. 11. ed. Munique: Beck, 2008;

FERRAZ JR., Tercio Sampaio. Teoria da norma jurídica: ensaio da pragmática da comunicação normativa. Rios de Janeiro: Forense, 1978

FERRAZ JR., Tercio Sampaio. Direito, retórica e comunicação: subsídios para uma pragmática do discurso jurídico. 2. ed. São Paulo: Saraiva, 1997

FERRAZ JR., Tercio Sampaio. Introdução ao estudo do direito: técnica, decisão, dominação. 3. ed. São Paulo: Atlas, 2001;

FERRAZ JR., Tercio Sampaio. Direito Constitucional: liberdade de fumar, privacidade, Estado, direitos humanos e outros temas. Barueri: Manole, 2007;

FERRAZ JR., Tercio Sampaio. As origens do Estado contemporâneo ou o Leviathan gestor da economia, in: FERRAZ JR., Tercio Sampaio. Direito Constitucional: liberdade de fumar, privacidade, Estado, direitos humanos e outros temas. Barueri: Manole, 2007;

FERRAZ JR., Tercio Sampaio. Princípio da eficiência, in: FERRAZ JR., Tercio Sampaio.

Direito Constitucional: liberdade de fumar, privacidade, Estado, direitos humanos e outros temas. Barueri: Manole, 2007;

FERRAZ JR., Tercio Sampaio. Hermenêutica constitucional: interpretação de bloqueio e de legitimação, in: FERRAZ JR., Tercio Sampaio. Direito Constitucional: 
liberdade de fumar, privacidade, Estado, direitos humanos e outros temas. Barueri: Manole, 2007;

FISCHMANN, Filipe. A função fática na Constituição Federal. Tese de Láurea apresentada à Faculdade de Direito da Universidade de São Paulo. São Paulo: 2006;

FOX, Eleanor M.. Consumer Beware Chicago, in: Michigan Law Review, Vol. 84, $\mathrm{N}^{\circ} 8$, Agosto de 1986, pp. 1714-1720;

FOX, Eleanor M.. "We protect competition, you protect competitors", in: World Competition, Vol. 26, № 2, 2003, pp. 149-165;

GERBER, David J. Law and competition in twentieth century Europe: protecting Prometheus. Oxford: Clarendon, 1998;

GERBER, David J.. Competition law and the institutional embeddedness of economics, in: DREXL, Josef; IDOT, Laurence; MONÉGER, Joël. Economic theory and competition law. Cheltenham: Elgar, 2009;

GOLDBERG, Daniel. Poder de Compra e política antitruste. São Paulo: Singular, 2006;

GRAU, Eros Roberto. Ensaio e discurso sobre a interpretaçãolaplicação do direito. 2. ed. São Paulo: Malheiros, 2003;

GRAU, Eros. A ordem econômica na Constituição de 1988. 9. ed. São Paulo: Malheiros, 2004;

HOVENKAMP, Herbert; JANIS, Mark D.; LEMLEY, Mark A. IP and antitrust: an analysis of antitrust principles applied to intellectual property law. Austin: Aspen, 2002;

HARROD, R.F.. Scope and method of economics, in: The Economic Journal, Vol. 48, ${ }^{\circ}$ 191, setembro de 1938, pp. 383-412;

HART, Herbert L.A. O conceito de direito. 5.ed. Lisboa: Fundação Calouste Gulbekian, 2007 (tradução da segunda edição inglesa);

HICKS, J. R. The foundations of welfare economics, in: The Economic Journal, Vol. 49, $\mathrm{N}^{\circ}$ 196, dezembro de 1939, pp. 696-712;

HOVENKAMP, Herbert. The first great law \& economics movement, in: Stanford Law Review, Vol. 42, № 4, abril de 1990, p. 993-1058;

IMMENGA, Ulrich. Ökonomie und Recht in der europäischen Wettbewerbspolitik, in: Zeitschrift für Wettbewerbsrecht (ZWeR), Vol. 4, N4, 2006, p. 365;

IRTI, Natalino. A ordem jurídica do mercado, in: Revista de Direito Mercantil, industrial, econômico e financeiro (RDM), Vol. 46, $\mathrm{N}^{\circ}$ 145, janeiro-março de 2007, pp. 44-49; 
KALDOR, Nicholas. Welfare Propositions of Economics and Interpersonal Comparisons of Utility, in: The Economic Journal, Vol. 49, N 195, setembro de 1939, pp. 549552 ;

KELSEN, Hans. Teoria pura do direito. São Paulo: Martins Fontes, 2000;

KERBER, Wolfgang. Should competition law promote efficiency? - Some reflections of an economist on the normative foundations of competition law, in: DREXL, Josef; IDOT, Laurence; MONÉGER, Joël. Economic theory and competition law. Cheltenham: Elgar, 2009;

JAKOBSON, Roman. Lingüística e comunicação. São Paulo: Cultrix, 2001;

JAKOBSON, Roman. Lingüística e poética, in: JAKOBSON, Roman. Lingüística e comunicação. São Paulo: Cultrix, 2001, pp. 118-162. Também o original deste texto: JAKOBSON, Roman. Closing statement: linguistics and poetics, in: SEBEOK, Thomas (Org.). Style in language. Nova Iorque: Wiley, 1960, pp. 350377 ;

JAKOBSON, Roman. Aspectos lingüísticos da tradução, in: JAKOBSON, Roman Lingüística e comunicação. São Paulo, Cultrix, 2001;

JAKOBSON, Roman. A linguagem comum dos lingüistas e dos antropólogos, in JAKOBSON, Roman. Lingüística e comunicação. São Paulo, Cultrix, 2001, pp. 1533 ;

LUHMANN, Niklas. Rechtssoziologie. 3. ed. Opladen: Westdeutscher, 1987;

LUHMANN, Niklas. Die Wirtschaft der Gesellschaft. Frankfurt am Main: Suhrkamp, 1994;

MACCORMICK, Neil. Rhetoric and the rule of law: a theory of legal reasoning. Nova Iorque: Oxford, 2005;

MALINOWSKI, Bronislaw. A new instrument for the interpretation of law - especially primitive, in: The Yale Law Journal, Vol. 51, 1941-1942, pp. 1237-1254;

MALINOWSKI, Bronislaw. O problema do significado em linguagens primitivas, in: OGDEN, C. K.; RICHARDS, I. A.. O significado de significado. Rio de Janeiro: Zahar, 1972, pp. 295-330. Também o orginial deste texto: MALINOWSKI, Bronislaw. The problem of meaning in primitive languages, in: OGDEN, C. K.; RICHARDS, I. A. The meaning of meaning: a study of the influence of language upon thought and of the science of symbolism. Londres: Routledge, 1994, pp. 435496;

MANKIW, N. Gregory. Principle of economics. 3.ed. Mason: Thomson, 2004; 
MATTOS, César (Org.). A revolução do antitruste no Brasil: a teoria econômica aplicada a casos concretos. São Paulo: Singular, 2003;

MATTOS, César. Introdução, in: MATTOS, César (Org.). A revolução do antitruste no Brasil: a teoria econômica aplicada a casos concretos. São Paulo: Singular, 2003;

MAXIMILIANO, Carlos. Hermenêutica e interpretação do direito. 19. ed. Rio de Janeiro: Forense, 2004;

MILLER, Roger LeRoy. Economics today. 15. ed. Boston: Addison-Wesley, 2010;

NOLL, Peter. Gesetzgebungslehre. Reinbek bei Hamburg: Rowohlt, 1973;

NUSDEO, Fábio. Curso de economia: introdução ao direito econômico. 3. ed. São Paulo: RT, 2001;

OGDEN, C. K.; RICHARDS, I. A. O significado de significado. Rio de Janeiro: Zahar, 1972. Também o original deste texto: OGDEN, C. K.; RICHARDS, I. A. The meaning of meaning: a study of the influence of language upon thought and of the science of symbolism. Londres: Routledge, 1994;

PEARSALL, Judy (Ed.). Concise oxford english dictionary. 10. ed. Nova Iorque: Oxford, 2002;

PIGOU, A. C.. The economics of welfare. 4. ed. Londres: Macmillan, 1952;

POSNER, Richard A.. Economics, politics, and the reading of statutes and the Constitution, in: The University of Chicago law review, Vol. 49, № 2, primavera de 1982, pp. 263-291;

POSNER, Richard A.. Statutory interpretation: in the classroom and in the courtroom, in: The University of Chicago law review, Vol. 50, $\mathrm{N}^{\circ}$ 2, primavera de 1983, pp. 800822 ;

POSNER, Richard A.. The law and economics movement, in: The American Economic Review, Vol. 77, $\mathrm{N}^{\circ}$ 2, Papers and proceedings of the ninety-ninth annual meeting of the American Economic Association, maio de 1987, pp. 1-13;

POSNER, Richard A. Law and legal theory in the UK and USA. Oxford: Oxford, 1996;

POSNER, Richard A.. Economic analysis of law. 7. ed. Nova Iorque: Aspen, 2007;

PRIEST, George L.. The Common Law Process and the Selection of Efficient Rules, in: The Journal of Legal Studies, Vol. 6, № 1, janeiro de 1977, pp. 65-82;

REIMANN, Mathias. Historische Schule und Common Law: die deutsche Rechtswissenschaft des 19. Jahrhunderts im amerikanischen Rechtsdenken. Berlim: Duncker\&Humblot, 1993; 
REY, Patrick et alii. Report by the EAGCP : “An economic approach to Article 82”, 2005, disponível em http://ec.europa.eu/competition/publications/studies/eagcp_july_21_05.pdf (último acesso em 15 de dezembro de 2009);

ROBBINS, Lionel. Interpersonal comparisons of utility: a comment, in: The Economic Journal, Vol. 48, $\mathrm{N}^{\circ}$. 192, dezembro de 1938, pp. 635-641;

RUBIN, Paul H.. Why Is the Common Law Efficient?, in: The Journal of Legal Studies, Vol. 6, $\mathrm{N}^{\circ}$ 1, janeiro de 1977, pp. 51-63;

RUBIN, Paul H.. Common law and statute law, in: The Journal of Legal Studies, Vol. 11, $\mathrm{N}^{\circ} 2$, junho de 1982, pp. 205-223;

SALOMÃO FILHO, Calixto. Direito concorrencial - as estuturas. São Paulo: Malheiros, 1998 ;

SEBEOK, Thomas (Org.). Style in language. Nova Iorque: Wiley, 1960, pp. 350-377;

SHAVELL, Steven. Foundations of economic analysis of law. Cambridge: Harvard, 2004;

STAMMLER, Rudolf. Wirtschaft und Recht nach der materialistischen Geschichtsauffassung: eine sozialphilosophische Untersuchung. 2. ed. Leipzig: Veit, 1906;

SULLIVAN, Lawrence A.; GRIMES, Warren S.. The law of antitrust: an integrated handbook. 2. ed. St. Paul: Thomson West, 2006,

TELLES JR., GOFFREDO. Iniciação na ciência do direito. São Paulo: Saraiva, 2001;

TULLOCK, Gordon. Trials on trial: the pure theory of legal procedure. Nova Iorque: Columbia, 1980;

VIEHWEG, Theodor. Rechtsphilosophie und Rhetorische Rechtstheorie: gesammelte kleine Schriften. Baden-Baden: Nomos, 1995;

VIEHWEG, Theodor. Rhetorik, Sprachpragmatik, Rechtstheorie, in: VIEHWEG, Theodor. Rechtsphilosophie und Rhetorische Rechtstheorie: gesammelte kleine Schriften. Baden-Baden: Nomos, 1995;

WARAT, Luis Alberto. O direito e sua linguagem. 2. ed. Porto Alegre: Fabris, 1995;

WARD, Greogory; HORN, Laurence R.. Phatic communication and relevance theory: a reply to Žegarac \& Clark, in: Journal of Linguistics, Vol. 35, Novembro de 1999, pp. 555-564;

WATZLAWICK, Paul; BEAVIN, Janet Helmick; JACKSON, Don D. Pragmática da Comunicação humana: um estudo dos padrões, patologias e paradoxos da interação. São Paulo: Cultrix, 2001; 
WEBER, Max. Wirtschaft und Gesellschaft: grundriß der verstehenden Soziologie. 5. ed. Tübingen: Mohr Siebeck, 1980;

WITZTUM, Amos. Economics: an analytical introduction. Oxford: Oxford, 2005;

WRÓBLEWSKI, Jerzy. The judicial application of law. Dordrecht: Kluwer, 1992;

ŽEGARAC, Vlad; CLARK, Billy. Phatic interpretations and phatic communication, in: Journal of Linguistics, Vol. 35, № 2, Julho de 1999, pp. 321 -346;

ŽEGARAC, Vlad; CLARK, Billy. Phatic communication and Relevance Theory: a reply to Ward \& Horn, in: Journal of Linguistics, Vol. 35, № 3, Novembro de 1999, pp. 565-577. 